\title{
Economic Return versus Crop Water Productivity of Watermelon under Full and Deficit Irrigation Conditions
}

\author{
Hayrettin KUȘC:U1* \\ Bilge KESKIN'
}

\author{
Ahmet TURHAN² \\ Ezgi KURTULMUȘ'
}

\author{
Hakan BÜYÜKCANGAZ \\ Ali Osman DEMiR'
}

\begin{abstract}
'Uludag University, Faculty of Agriculture, Biosystems Engineering Department, 16059 Bursa, Turkey;
2Uludag University, Mustafakemalpasa Vocational School, Crop and Animal Production Department, Bursa, Turkey
\end{abstract}

${ }^{*}$ corresponding authore-mail(sorumlu yazar e-mail) kuscu@uludag.edu.tr

Geliș tarihi (Received) : 02.01.2017

Kabul tarihi (Accepted): 15.02.2017

\begin{abstract}
Field research was carried out in a sub humid climate at the Uludag University, Bursa, Turkey. Using the yield data obtained from the field research for 2011 and 2012, a partial economic analysis was conducted for watermelon (Citrullus vulgaris, var. Crimson Sweet) at four drip irrigation treatments of full irrigation [FI, 100\% evapotranspiration (ET $)$ ] and deficit irrigation (DI) [75\% FI, 50\% FI and 25\% FI] and then compared to both physical and economic water use efficiency (WUE). Total costs and net incomes differed among irrigation strategies. Marketable yield (MY) and net income to land decreased with decreases in the amount of irrigation. The highest MY and net income to land were obtained with the full irrigation treatment. The results showed that full irrigation is recommended under non-water-limiting environments for higher yield and net income. The highest net income to water, physical WUE and economic WUE values were resulted from the $75 \% \mathrm{FI}$. With consideration to net income and water use efficiency, deficit irrigation management strategy of $75 \%$ Fl under water-limiting conditions can be preferable, because it achieved irrigation water savings of $25 \%$, an increase of $9 \%$ in crop water use efficiency and an acceptable net income with a yield loss of only approximately 8\% compared with full irrigation.
\end{abstract}

Key Words: Citrullus vulgaris, limited irrigation, economic analysis, evapotranspiration, water use efficiency

\section{Tam ve Kısıntılı Sulama Koșullarında Karpuzun Su Kullanım Etkinliği Karșısında Ekonomik Getirisi}

\section{Öz}

Tarla denemeleri, yarı nemli bir iklimde (Uludağ Üniversitesi, Bursa, Türkiye) yürütülmüștür. Tarla denemelerinden 2011 ve 2012 yıllarında elde edilen veri kullanılarak, tam sulama [FI, \%100 bitki su tüketimi (ET)] ve kısıntılı sulama (DI) [\%75 FI, \%50 FI ve \%25 FI] konularını içeren ve damla sulama ile sulanan karpuz (Citrullus vulgaris, Crimson Sweet çeșidi) için bir kısmi ekonomik analiz gerçekleștirilmiș ve sonrasında sonuçlar fiziksel ve ekonomik su kullanım etkinliği (WUE) ile karșılaștııımıștır. Toplam maliyetler ve net kazançlar sulama stratejileri arasında farklılık göstermiștir. Pazarlanabilir verim (MY) ve arazi bașına net kazanç, sulama miktarındaki azalmayla azalmıștır. En yüksek MY ve arazi bașına net kazanç, tam sulama konusundan elde edilmiștir. Elde edilen sonuçlara göre, daha yüksek verim ve net kazanç için suyun kısıtlı olmadığı çevrelerde tam sulama konusu tavsiye edilmektedir. Birim su bașına net kazanç, fiziksel WUE ve ekonomik WUE' nin en yüksek değerleri \%75 FI denemesinden elde edilmiștir. Net kazanç ve su kullanım etkinliği birlikte değerlendirildiğinde, suyun kısıtlı olduğu koșullarda \%75 FI kısıntılı sulama stratejisi tercih edilebilir. Bu strateji ile tam sulama konusuna kıyasla \%25 sulama suyu tasarrufu, bitki su kullanım etkinliğinde \%9'luk bir artıș ve yalnızca \%8'lik bir verim azalmasılyla kabul edilebilir düzeyde net kazanç elde edilmiștir.

Anahtar Kelimeler: Citrullus vulgaris, kısıntılı sulama, ekonomik analiz, evapotranspirasyon, su kullanım etkinliği 


\section{INTRODUCTION}

Water is generally the most vital factor limiting expansion and development of agriculture in Marmara region, a sub-humid climate of Turkey (Karasu et al., 2015). The Marmara, the most crowded region of Turkey, is experiencing a serious water scarcity in dry years. The region receives sufficient rainfall during September to May whereas the other months are relatively drier. The main irrigation water sources for dryseason crop production are commonly irrigation canals constructed by the General Directorate of State Hydraulic Works. During the last 20 years, Marmara region experienced a few meteorological droughts in 1996, 2001, 2007 and 2013 which has adversely affected crop yield. To meet the growing food needs of increasing population, it is necessary to increase theyield per unit area (vertical expansion) or open up the new agricultural lands (horizontal expansion) to the agricultural production. Developing stress/drought-tolerant crop varieties, irrigation scheduling based on water saving and cultivating low water-demand crops may be strategic approaches in achieving sustainable agriculture (Qadir et al., 2003; Ali et al., 2007). Water consumption can be reduced by DI strategies without any adverse effect on yield (Zhang et al., 2004; Ali et al., 2007). To pursue this strategy, it is crucial to identify crop yield response to DI conditions. It is also substantial to compare the financial returns or economic advantages under full irrigation and DI (Ali et al., 2007).

Net farm income may be increased by reducing costs through DI strategies as many researchers have concluded (de Andrade et al., 2001; Lu et al., 2003; Namdari, 2011; Moradi et al., 2015). The possible gains of $\mathrm{DI}$ can be achieved by that factors such as reduced irrigation cost, increased water use efficiency and the opportunity cost of water (English, 1990). Reduced yield under DI conditions may be recovered by increasing production from the extra area irrigated by the water gained DI (Ali et al., 2007).

In former researches, it is summarized that watermelon yield reduces at DI conditions (Wang et al., 2004; Erdem et al., 2005; Kușçu et al., 2015). Erdem and Yuksel (2003) investigated the yield response of watermelon to DI. They reported from a 2-years study that well irrigated crops produced the highest yield and flowering was the most sensitive phenologic stage to soil water deficit. However, they did not evaluate water use efficiency and net farmer incomes under different DI strategies.

At the South-eastern Anatolian Project Region of Turkey, Simsek et al. (2004) reported the highest watermelon fruit yield with a 1.25 ratio of irrigation water/cumulative pan evaporation. Rouphael et al. (2008) found that marketable yield decreased with DI, but WUE increased under DI conditions. Leskovar et al. (2003) observed that severe DI decreased fruit yield of some cultivars of diploid and triploid watermelon, and contents of vitamin C and lycopene did not reduce with DI at 0.75 evapotranspiration.

Many studies have been done in many different ecological conditions to conclude the effects of DI on yield and yield-water relations of watermelon. However, studies which investigated the economic return are rare to choose the most economic irrigation program. Water scarcity is often a much less important problem for farmers than soil limitations such as insufficient water holding capacity, soil salinity and shallowness, etc. because their main goal is to maximize their income per area (Luquet et al., 2005). Before DI can be accepted as a management strategy, its effect on marketable yield, quality and net income should be determined based on water-yield relationships and an economic evaluation (Kușçu et al., 2014). We examined the effects of full and deficit irrigation strategies on yield, physical and economic water use efficiency, and the net income of watermelon production in southern Marmara Region of Turkey.

\section{MATERIAL AND METHODS}

Field experiments of watermelon (Citrullus Vulgaris) were conducted at the University of Uludag-Mustafakemalpasa Vocational School Agricultural Research Center, Bursa, Turkey [40.03 $\mathrm{N}$ and $28.38^{\circ} \mathrm{W}$ ] in 2011 and 2012. The local climate is temperate, the summers are hot and dry, and the winters are mild and rainy. According to long-term meteorological data (1975-2010), the annual mean rainfall, temperature, and relative humidity are $681 \mathrm{~mm}$, $14{ }^{\circ} \mathrm{C}$, and $68 \%$, respectively. The total rainfall during the growing season was $52 \mathrm{~mm}$ in 2011 and $103 \mathrm{~mm}$ in 2012. The climate in this part of 
the country is classified as sub-humid according to the Thornthwaite climate classification system (Feddema, 2005). The soil structure is clay loam. Average field capacity was 35\%, wilting point $20 \%$, bulk density $1.38 \mathrm{~g} \mathrm{~cm}^{-3}$ and total available moisture (TAM) $186 \mathrm{~mm}$ for $0-90 \mathrm{~cm}$ soil depth based on gravimetrical method.

The research was carried out in a completely randomized block design with three replications. The irrigation treatments under investigation were fully irrigated $(\mathrm{FI}), 75 \%$ of $\mathrm{Fl}, 50 \%$ of $\mathrm{Fl}$, and $25 \%$ of $\mathrm{Fl}$. The treatments were realized based on soil water depletion (SWD) replenishments. The fully irrigated treatment was designed to receive $100 \%$ SWD when approximately 30\% of TAM was depleted. The soil water content was observed at $0.3 \mathrm{~m}$ incremental depths to $1.2 \mathrm{~m}$ prior to and after irrigation from each plot in all randomized blocks throughout the whole growing season.

Watermelon seedlings (Crimson Sweet variety) were transplanted to the treatment plots, on 23 and 16 May in 2011 and 2012 respectively. Watermelon was grown on 12 plots $(4.8 \times 5.0 \mathrm{~m})$ and each DI treatment was applied on three plots for both experiments. The plant-plant spacing and row spacing were 1.0 and $1.2 \mathrm{~m}$, respectively. A total of $100 \mathrm{~kg} \mathrm{~N} \mathrm{ha}^{-1}$ and $50 \mathrm{~kg}$ P2O5 ha-1 fertilizer was applied to the experimental field in the light of recommendations based on the soil productivity analysis.

The drip irrigation method was used for irrigation. The laterals were installed in each row (1.2 m apart). The thick-walled dripper lines have possessed inline compensating emitter pressure, and the emitters' discharge rate was $3.0 \mathrm{~L} \mathrm{~h}^{-1}$ under pressure of $1 \mathrm{~atm}$. The emitter spacing was selected as $0.40 \mathrm{~m}$ based on the soil physical characteristics (Yıldırım, 2013). The water was supplied from the Mustafakemalpasa Aquifer. Water was given into the plot based on the calculated volume. The system was installed in the plots before transplanting in both seasons. Irrigation water was applied to all plots during transplantation in order to bring existing soil moisture in the field capacity to a $90 \mathrm{~cm}$ soil depth (43 $\mathrm{mm}$ in 2011 and $31 \mathrm{~mm}$ in 2012).

Soil moisture was gravimetrically determined. While the moisture content of $0.9 \mathrm{~m}$ was used for the calculation of applied water amount in each irrigation, that of $1.2 \mathrm{~m}$ soil depth was employed for the seasonal crop evapotranspiration rate. Soil water balance method was applied to determine crop seasonal evapotranspiration ( $E T_{c}$ ) for each plot (Yıldırım et al., 2009). The actual crop ET, under the different irrigation treatments was estimated using the following soil water balance equation (Garrity et al., 1982):

$$
\mathrm{ET}_{\mathrm{c}}=\mathrm{I}+\mathrm{P} \pm \Delta \mathrm{S}-\mathrm{D}
$$

where I is the irrigation water $(\mathrm{mm}), P$ is the precipitation $(\mathrm{mm}), \Delta \mathrm{S}$ is the change in soil water storage $(\mathrm{mm})$ and $D$ is the deep percolation below the root zone. In the equation, I was measured using water meters, P was observed at the automated weather observing station located $1 \mathrm{~km}$ east of the experimental area and $\Delta \mathrm{S}$ was obtained from gravimetric moisture observations in the soil profile to a depth of $0.9 \mathrm{~m}$. Whenever the available water in the root zone $(0-0.9 \mathrm{~m})$ and the total amount of water applied by irrigation or rainfall were above the field capacity, the water was assumed to enter the deep percolation below the root zone.

During both the years, the watermelon fruits were harvested during last week of August.

Gross and net income was assessed by partial economic analysis for all treatments. Gross income was determined using the two-year average market price (TL 0.25 per $\mathrm{kg}$ ) of watermelon fruit in the study area; and net income to land (TL ha' I) was calculated by subtracting total operational costs from gross income. Net income to water (TL $\mathrm{m}^{-3}$ ) also calculated by dividing the irrigation water amount per unit area of the net income to land. The cost of irrigation labour for each treatment was estimated by multiplying the hourly labour cost (TL 4.72 hour $^{-1}$ ) and the seasonal irrigation duration (hour ha-1). The hourly labour cost was estimated by dividing the average daily wage of seasonal agricultural workers in 2011 and 2012 years by the daily working time (8 hours). The seasonal irrigation duration was found by dividing by the seasonal irrigation water amount per unit area by the hourly irrigation water amount per hectare based on the drip irrigation system characteristics. The energy cost of water pumping via electrical pump with assumed $15 \mathrm{~kW}$ motor was calculated by multiplying the seasonal irrigation duration, and electrical energy cost and the $15 \mathrm{~kW}$. The unit cost of electrical energy was averaged over the study period assuming a TL 0.35 per kW for electricity 
tariff for agricultural irrigation in Bursa, Turkey (EE, 2016). The water cost for each treatment was estimated by multiplying the cost of a unit volume of water (TL 0.05 per hectare) determined for the study area by General Directorate of State Hydraulic Works and the total amount of irrigation water required for each irrigation treatment. All other production costs including land preparation, fertilizers, chemicals (insecticides and pesticides), seedlings and labour (planting, weeding and other cultural applications) were presumed constant through all irrigation treatments. In 2012 harvest period, personal interviews were conducted with representatives of Bursa-Mustafakemalpasa Directorate of District Food Agriculture and Livestock and local farmers to take information that would specify the plant management practices. Since the research objective of this study is to evaluate various irrigation management practices, farm rent and agricultural equipment fee were excluded in the economic analysis.

Physical water use efficiency (PWUE, $\mathrm{kg} \mathrm{m}^{-3}$ ) based on ET was estimated as marketable yield $(\mathrm{kg}$ $\mathrm{ha}^{-1}$ ) obtained from per unit volume of seasonal ETc $\left(m 3 h^{-1}\right)$. Economic water use efficiency based on the gross income $\left(E W U E_{\text {gross' }} \mathrm{TL} \mathrm{m}^{-3}\right)$ was estimated as gross income (TL ha' $\left.{ }^{-1}\right)$ obtained from per unit amount of seasonal ETc (m3 ha $\left.{ }^{-1}\right)$. Economic water use efficiency based on the net

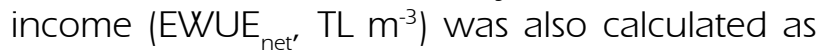
the net income (TL ha ${ }^{-1}$ ) obtained from per unit amount of seasonal ETc (m3 ha' ${ }^{-1}$ ).

The yield data were subjected to analyses of variance using SPSS 23 software. LSD test was used to group the means of irrigation when the F-test was significant. Regression analysis was also carried out to examine relationships between water and yield and net return.

\section{RESULTS AND DISCUSSIONS}

\section{Irrigation water amount, evapotranspiration and yield}

Average results of the irrigation amounts applied to the experimental treatments, the seasonal evapotranspiration and the marketable yield values are shown in Table 1. The greatest amount of irrigation water was given in the fully irrigated treatment. Crops in DI treatments suffered prolonged water stress through total crop growing season.

The seasonal ETc varied between 2,980 and $5,050 \mathrm{~m}^{3} \mathrm{ha}^{-1}$. As expected, the highest seasonal $E T_{c}$ was recorded in the full irrigation, clearly owing to favourable soil moisture conditions during total growing period, whereas the lowest seasonal ET, was observed in the $25 \% \mathrm{Fl}$ strategy, with a severe water deficit (Table 1).

The DI strategies adversely affected marketable watermelon yield as like to the findings given by Erdem et al. (2005). The heaviest fruits in weight were obtained from full irrigation treatment during the growing season (Table 1). On average, the mild water deficit (75\% FI) saved about 25\% water compared to the full irrigation, with a yield decrease of $8 \%$. The lowest marketable yield was recorded from the 25\% Fl strategy. The reason of low yield associated with that treatment is that the soil moisture is low during crop growing season, resulting in low fruit water content. Results are in agreement with many studies conducted in a wide range of environments which confirm that irrigation can significantly affect the yield increase of watermelon (Tingwu et al., 2003; Kirnak and Dogan, 2009; Pejié et al., 2016).

Table 1. Average results of seasonal irrigation water applied, seasonal actual crop evapotranspiration and marketable yield for full irrigation (FI) and different deficit irrigation (75\% FI, 50\% FI and 25\% FI).

Çizelge 1. Tam sulama (FI) ve kısıntılı sulama (\%75 Fl, \%50 Fl ve \%25 Fl) için ortalama mevsimlik sulama suyu, mevsimlik bitki su tüketimi ve pazarlanabilir verim

\begin{tabular}{lccc}
\hline Irrigation treatment & $\begin{array}{c}\text { Seasonal irrigation } \\
\text { water applied }\left(\mathrm{m}^{3} \mathrm{ha}^{-1}\right)\end{array}$ & $\begin{array}{c}\text { Seasonal actual crop } \\
\text { evapotranspiration }\left(\mathrm{m} 3 \mathrm{ha}^{-1}\right)\end{array}$ & $\begin{array}{c}\text { Marketable yield (kg } \\
\left.\mathrm{ha}^{-1}\right)\end{array}$ \\
\hline Full irrigation (FI) & 4,490 & 5,050 & $79,100 \mathrm{al}$ \\
$75 \% \mathrm{FI}$ & 3,370 & 4,240 & $72,600 \mathrm{~b}$ \\
$50 \% \mathrm{FI}$ & 2,250 & 3,720 & $58,000 \mathrm{c}$ \\
$25 \% \mathrm{FI}$ & 1,130 & 2,980 & $37,700 \mathrm{~d}$ \\
\hline
\end{tabular}

'Means followed by the different letter significantly different at 0.05 level by LSD test. 


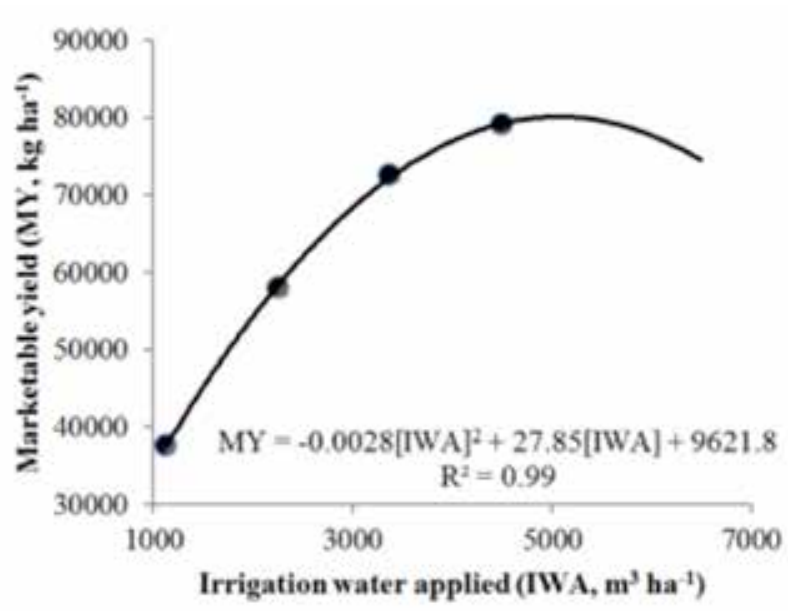

Figure 1. Water and yield relationships

Sekil 1. Su-verim ilișkileri

The applied seasonal irrigation water amount and marketable yield $\left(R^{2}=0.99\right)$ demonstrated strong quadratic relationship whereas relationship between seasonal evapotranspiration and marketable yield $\left(R^{2}=0.93\right)$ was linear (Figure 1). An increase in seasonal water amount applied nearly up to $5000 \mathrm{~m}^{3} \mathrm{ha}^{-1}$ increased the marketable yield, and thereafter yield tended to decrease. At higher levels of applied water the function begins to curve over, reflecting various water losses such as deep percolation. A quadratic relationship between seasonal irrigation and yield for watermelon was reported by a few researchers (Erdem et al., 2005; Kușçu et al., 2015).

\section{Economic return}

The price of watermelon fruit and the irrigation cost, as well as the effect of water on fruit yield, should be taken into consideration to gain the maximum profit from irrigation management. Costs and incomes for different

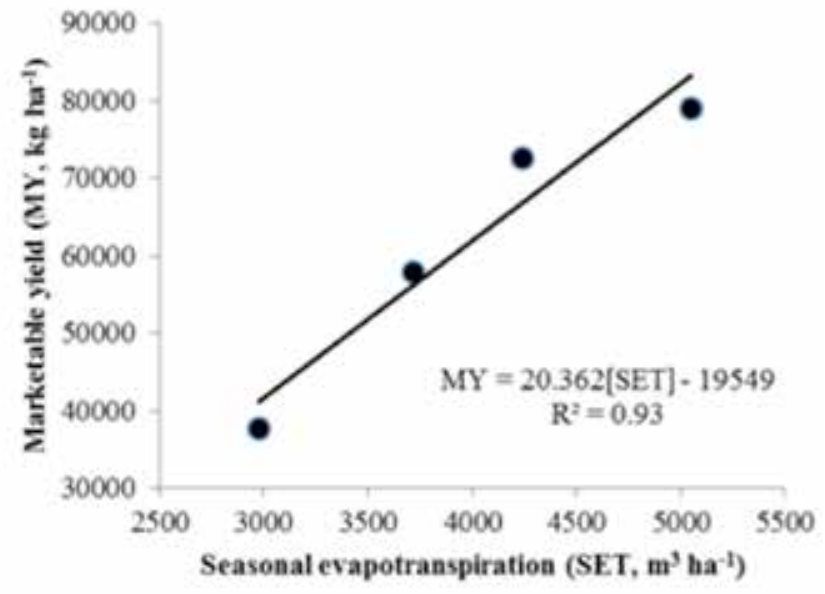

irrigation scenarios are shown in Tables 2 and 3, respectively. The water pricing was determined by the amounts of canal water used by the growers and averaged to reflect the actual water price in the experimental area. Irrigation water cost was TL $0.05 \mathrm{~m}^{-3}$ for farm conditions. Costs of water, water pumping, and irrigation labour increased with increments in the irrigation water amount, and the highest total operational cost was found at full irrigation treatment (Table 2).

Both the gross income and the net income to land were highest for the full irrigation treatment, followed by the $75 \% \mathrm{FI}$ treatment (Table 3). In contrast, the $25 \% \mathrm{FI}$ treatment with severe water deficit produced the lowest net income to land. On the other hand, the net income to water was highest for $75 \% \mathrm{FI}$ treatment, while the lowest net income to water was obtained from 25\% Fl treatment. These low net income values for $25 \% \mathrm{Fl}$ treatment were due, in part,

Table 2. Irrigation labour cost, water pumping cost, water cost, crop management cost and total operational cost for different irrigation strategies

Çizelge 2. Farklı sulama stratejileri için sulama ișçilik maliyeti, su basma maliyeti, su maliyeti, bitki yönetim maliyeti ve toplam ișletme maliyeti

\begin{tabular}{lccccc}
\hline Irrigation treatment & $\begin{array}{c}\text { Irrigation } \\
\text { labour cost } \\
\left(\text { TL ha }^{-1}\right)\end{array}$ & $\begin{array}{c}\text { Energy cost } \\
(\text { water pumping) } \\
\left(\mathrm{TL} \mathrm{ha}^{-1}\right)\end{array}$ & $\begin{array}{c}\text { Water cost } \\
\left.(\mathrm{TL} \mathrm{ha})^{-1}\right)\end{array}$ & $\begin{array}{c}\text { Crop } \\
\text { management } \\
\text { cost }\left(\mathrm{TL} \mathrm{ha}^{-1}\right)\end{array}$ & $\begin{array}{c}\text { Total } \\
\text { operational } \\
\text { cost }\left(\mathrm{TL} \mathrm{ha}^{-1}\right)\end{array}$ \\
\hline Full irrigation (FI) & 318 & 377.2 & 224.5 & 9000 & 9919.9 \\
$75 \% \mathrm{FI}$ & 239 & 283.1 & 168.5 & 9000 & 9690.4 \\
$50 \% \mathrm{FI}$ & 159 & 189.0 & 112.5 & 9000 & 9461.0 \\
$25 \% \mathrm{FI}$ & 80 & 94.9 & 56.5 & 9000 & 9231.5 \\
\hline
\end{tabular}


Table 3. Gross income, net income to land and net income to water for different irrigation strategies

Çizelge 3. Farklı sulama stratejileri için brüt kazanç, arazi bașına net kazanç, ve su bașına net kazanç

\begin{tabular}{llll}
\hline Irrigation treatment & Gross income $\left(\mathrm{TL} \mathrm{ha}^{-1}\right)$ & $\begin{array}{l}\text { Net income to land }(\mathrm{TL} \\
\left.\mathrm{ha}^{-1}\right)\end{array}$ & Net income to water $\left(\mathrm{TL} \mathrm{m}^{-3}\right)$ \\
\hline Full irrigation (FI) & 19,775 & 9,855 & 2.19 \\
$75 \% \mathrm{FI}$ & 18,150 & 8,460 & 2.51 \\
$50 \% \mathrm{FI}$ & 14,500 & 5,039 & 2.24 \\
$25 \% \mathrm{FI}$ & 9,425 & 193 & 0.17 \\
\hline
\end{tabular}

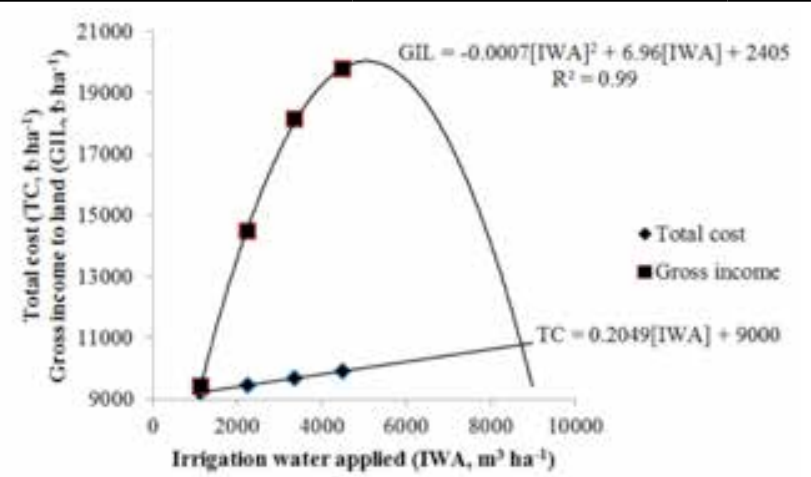

Figure 2. Total cost and gross income to land versus irrigation water applied

Șekil 2. Uygulanan sulama suyu karșısında toplam maliyet ve arazi bașına net kazanc
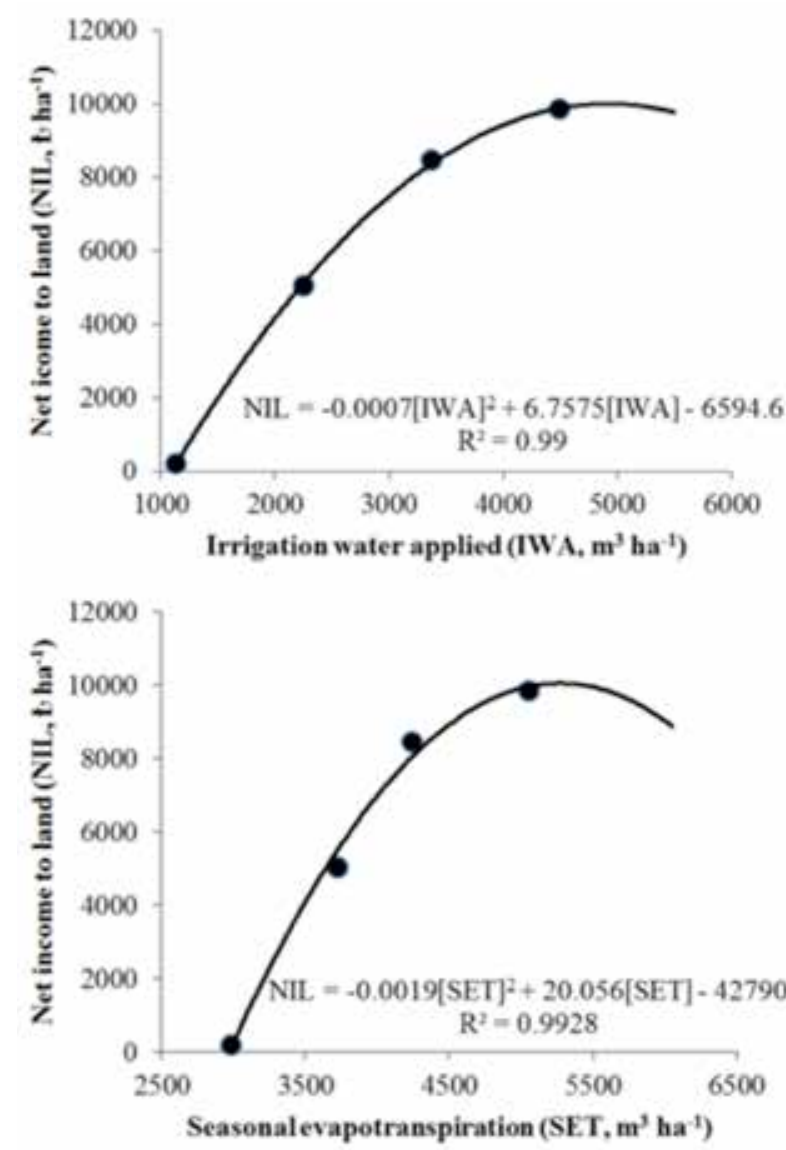

Figure 3. Water and net income relationships

Sekil 3. Su ve net kazanç ilișkileri to lower marketable yield values. Therefore, this irrigation treatment must not be used for deficit irrigation management of watermelon in the study area. Production using this treatment would be uneconomical for the producers. This study showed that full irrigation is the best water regime to use to provide higher yield and net income under drip irrigation in the scarcity of land resource. The results of this study also showed that in conditions of water resources scarcity, water application 75\% of full irrigation is a more viable option.
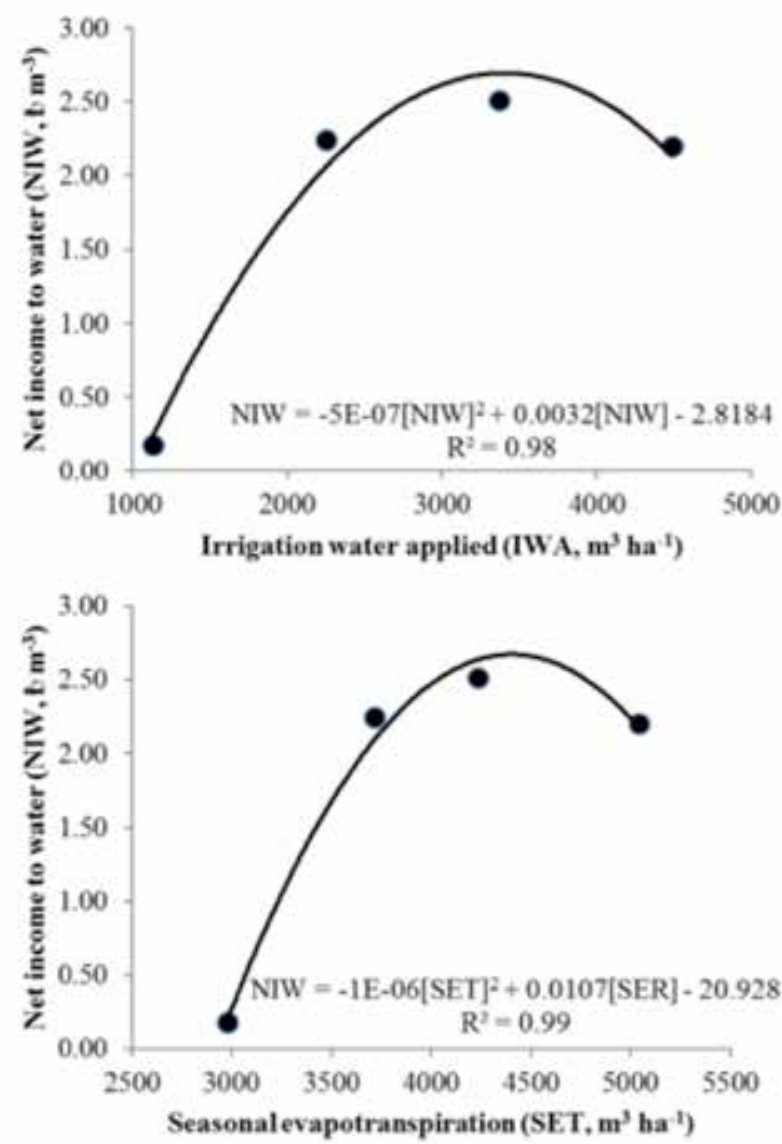
Total cost and gross income to land versus irrigation water applied are shown in Figure 2. Total cost linearly increases with increases in the irrigation water applied, while gross income to land versus irrigation water applied shows a strong quadratic relationship $\left(R^{2}=0.99\right)$. When considering the data the forecasting for more irrigation amounts from mentioned quadratic relationship equation, the gross income to land reaches maximum level with approximately 5000 $\mathrm{m}^{3} \mathrm{ha}^{-1}$ of irrigation water, and thereafter it tends to decline. When considering the gross income to land and the total cost, the net income to land lows to zero with approximately $8700 \mathrm{~m}^{3} \mathrm{ha}^{-1}$ of irrigation water. On the other hand, there were close relationships between irrigation water applied or evapotranspiration and net income calculated for either land or water (Figure 3). The relationships between net income per either land or water and irrigation water applied are shown in Figure 3a-b. The relationships were mainly quadratic. In this study, quadratic relationships between net return to land or water and seasonal evapotranspiration were also determined (Figure 3c-d). Farmers who want to maximize their revenues can benefit from equations in Figure 3.

\section{Water use efficiency}

Physical water use efficiency (PWUE), economic water use efficiency based on the gross income (EWUE $\left.{ }_{\text {gross }}\right)$ and economic water use efficiency based on the net income $\left(E W U E_{n e t}\right)$ were influenced by irrigation scenarios (Table 4).

Mild water deficit effectively increased water use efficiency. The highest values of PWUE, EWUE ${ }_{\text {gross }}$ and EWUE $_{\text {net }}$ were obtained under mild deficit strategy (75\% of full irrigation), indicating that the most efficient and economical use of irrigation water was performed in this treatment. Conversely, the lowest values of water productivity indices were found at severe deficit strategy (25\% full irrigation), implying that irrigation water was not efficiently used in this treatment. The range of physical water use efficiency values obtained from this research is consistent with previously reported values for watermelon (Erdem et al., 2005; Pejié et al., 2016).

\section{CONCLUSIONS}

According to the results of our study, different irrigation strategies influenced yield, net return and crop productivity of watermelon in Southern Marmara Region of Turkey. The yield in full irrigation conditions $\left(79,100 \mathrm{~kg} \mathrm{ha}^{-1}\right)$ was 2 times higher $\left(37,700 \mathrm{~kg} \mathrm{ha}^{-1}\right)$ as compared with severe deficit irrigation (25\% full irrigation). DI decreased yield and net income to land. However, farmers should accept the DI strategy to achieve an economic crop production in water-short areas. The findings of this study may provide guidelines for the development of improved irrigation management practices for sub-humid zones. If water is limited, mild deficit irrigation (75\% full irrigation) applied during total growing season could be suggested to enhance net income to water, PWUE and EWUE based on the results of the two-year study. The suggested treatment may obtain irrigation water savings of $25 \%$ and an increase of approximately $9 \%$ in the crop water productivities compared to full irrigation. Our data also suggest that moderate water stress (50\% full irrigation) should be scheduled if irrigation is relatively restricted. The severe water deficit (25\% full irrigation) is not a desirable strategy under our experimental conditions.

Table 4. Water use efficiency indicators

Çizelge 4. Su kullanım etkinliği göstergeleri

\begin{tabular}{llll}
\hline Irrigation treatment & $\begin{array}{c}\text { Physical water use effi- } \\
\text { ciency }\left(\mathrm{kg} \mathrm{m}^{-3}\right)\end{array}$ & $\begin{array}{c}\text { Economic water use effi- } \\
\text { ciency based on the gross } \\
\text { income }\left(\mathrm{TL} \mathrm{m}^{-3}\right)\end{array}$ & $\begin{array}{c}\text { Economic water use effi- } \\
\text { ciency based on the net } \\
\text { income }\left(\mathrm{TL} \mathrm{m}^{-3}\right)\end{array}$ \\
\hline Full irrigation (FI) & 15.66 & 3.92 & 1.95 \\
$75 \% \mathrm{FI}$ & 17.12 & 4.28 & 2.00 \\
$50 \% \mathrm{FI}$ & 15.59 & 3.90 & 1.35 \\
$25 \% \mathrm{FI}$ & 12.65 & 3.16 & 0.06 \\
\hline
\end{tabular}




\section{References}

Ali M.H., Hoque M.R., Hassan A.A., Khair A. 2007. Effects of deficit irrigation on yield, water productivity, and economic returns of wheat. Agricultural Water Management, 92 (3): $151-161$.

de Andrade A.S., Frizzone J.A., Bastos E.A., Cardoso M.J., Rodrigues B.H.N. 2001. Optimal irrigation strategies for watermelon crop. Pesquisa Agropecuaria Brasileira, 36 (2): 301-305.

EE. 2016. Enerji Enstitüsü. Available: http:// enerjienstitusu.com/elektrik-fiyatlari/

English M. 1990. Deficit Irrigation. I: Analytical Framework. Journal of Irrigation and Drainage Engineering, 116 (3): 399-412.

Erdem Y., Yuksel A.N. 2003. Yield response of watermelon to irrigation shortage. Scientia Horticulturae, 98 (4): 365383.

Erdem Y., Erdem T., Orta A.H., Okursoy H. 2005. Irrigation scheduling for watermelon with crop water stress index (CWSI). Journal of Central European Agriculture, 6(4): 449-460.

Feddema J.J. 2005. A revised Thornthwaite-type global climate classification. Physical Geography. 26:442-466.

Garrity P.D., Watts D.G., Sullivan C.Y., Gilley J.R. 1982. Moisture deficits and grain sorghum performance, evapotranspiration yield relationships. Agronomy Journal, 74, 815-820.

Karasu A., Kușçu H., Öz M. 2015. Yield and economic return response of silage maize to different levels of irrigation water in a sub-humid zone. Zemdirbyste-Agriculture, 102(3): 313-318.

Kirnak H., Dogan E. 2009. Effect of seasonal water stress imposed on drip irrigated second crop watermelon grown in semi-arid climatic conditions. Irrigation Science, 27: 155164.

Kușçu H., Turhan A., Demir A.O. 2014. The response of processing tomato to deficit irrigation at various phenological stages in a sub-humid environment. Agricultural Water Management, 133: 92-103.

Kușçu H., Turhan A., Ozmen N., Aydınol P., Buyukcangaz H., Demir A.O. 2015. Deficit irrigation effects on watermelon (Citrullus Vulgaris) in a sub humid environment. The Journal of Animal and Plant Sciences, 25 (6):1652-1659.

Leskovar D.I., Bang H., Kolenda K., Franco J.A., PerkinsVeazie P. 2003. Deficit irrigation influences yield and lycopene content of diploid and triploid watermelon. Acta Horticulturae (ISHS) 628: 147-151.

Lu W., Duthie J.A., Roberts B.W., Taylor M.J., Edelson J.V. 2003. Partial budget analysis of effects of crop management intensity on profitability of three watermelon cultivars. Journal of Vegetable Crop Production, 9 (1): 49-71.
Luquet D., Vidal A., Smith M., Dauzat J. 2005. 'More crop per drop': how to make it acceptable for farmers? Agricultural Water Management, 76 (2): 108-119.

Moradi R., Moghaddam P.R., Mansoori H. 2015. Energy use and economical analysis of seedy watermelon production for different irrigation systems in Iran. Energy Reports, 1: 36-42.

Namdari M. 2011. Energy use and cost analysis of watermelon production under different technologies in Iran. International Journal of Environmental Sciences, 1 (6): 1144-1153

Pejić B., Mačkić K., Pavković S., Ljevnaić-Mašić B., Aksić M., Gvozdanović-Varga J. 2016. Water-yield relations of drip irrigated watermelon in temperate climatic conditions. Contemporary Agriculture, 65 (1 - 2):53-59.

Qadir M., Bores T.M, Schubert S., Ghafoor A., Murtaza G. 2003. Agricultural water management in water-starved countries: challenges and opportunities. Agricultural Water Management, 62:165-185.

Rouphael Y., Carderelli M., Colla G. 2008. Yield, mineral composition, water relations, and water use efficiency of grafted mini-watermelon plants under deficit irrigation. HortScience, 43 (3): 730-736.

Șimșek M., Kacira M., Tonkaz T. 2004. The effects of different drip irrigation regimes on watermelon [Citrullus lanatus (Thunb.)] yield and yield components under semiarid climatic conditions. Australian Journal of Agricultural Research, 55 (11): 1149-1157.

Tingwu L., Juan X., Guangyong L., Jianhua M., Jianping W., Zhizhong L., Jianguo Z. 2003. Effect of drip irrigation with saline water on water use efficiency and quality of watermelons. Water Resources Management, 17 (6): 395408.

Wang Y., Xie Z.K., Li .F, Zhang Z. 2004. The effect of supplemental irrigation on watermelon (Citrullus lanatus) production in gravel and sand mulched fields in the Loess Plateau of northwest China. Agricultural Water Management, 69 (1): 29-41.

Yıldırım O., Halloran N., Çavușoğlu Ș., Șengül N. 2009. Effects of different irrigation programs on the growth, yield, and fruit quality of drip-irrigated melon. Turkish Journal of Agricultural and Forestry, 33 (3): 243-255.

Yıldırım O. 2013. Sulama Sistemlerinin Tasarımı. Ankara Üniversitesi Ziraat Fakültesi Yayın No:1594, Ankara, p. 367.

Zhang J., Yang J. 2004. Improving harvest index is an effective way to increase crop water use efficiency. In: Proceedings of the 4th International Crop Science Congress, on the theme Crop Science for Diversified Planet, pp. 1-7, 21-25 September, Brisbane, Australia. 


\title{
Bazalt Ana Materyali ve Farklı Topografik Pozisyonlar Üzerinde Olușmuș Toprakların Bazı Topografik ve Fiziko- Kimyasal Özellikleri Arasındaki Doğrusal Regresyon Modellerinin Belirlenmesi
}

\author{
Imanverdi EKBERLi Orhan DENGIZ* \\ Ondokuz Mayıs Üniversitesi, Ziraat Fakültesi Toprak Bilimi ve Bitki Besleme Bölümü, SAMSUN \\ *sorumlu yazar e-mail (corresponding authore-mail): odengiz@omu.edu.tr
}

Geliș tarihi (Received) : 28.31.2016

Kabul tarihi (Accepted): 17.02.2017

Öz

Bu çalıșmanın amacı, farklı topografya ve arazi kullanım-örtü altında ancak, benzer jeolojik materyal üzerinde olușmuș altı farklı toprak profilinin zamana bağlı olarak lokal değișimlerinin incelenmesi ve eğim ile beraber ele alınan bazı fiziksel ve kimyasal toprak özellikleri arasında doğrusal regresyon modellerinin olușturulmasıdır. Bu kapsamda, Samsun-Bafra karayolunun güneyinde, Engiz Beldesine bağı Dağköy mevkii alanı içerisinde farklı topografik pozisyonlarda (tepe üstü düzlük/plato, yamaç, etek ve taban arazi) yer alan bazaltik ana materyal üzerinde olușmuș topraklarda fiziksel, kimyasal ve morfolojik özellikler belirlenmiș ve sınıflamaları yapıımıștır. Araștırma sonucuna göre, toprakların gerek arazi morfolojik incelemeleri gerekse de alınan toprak örneklerinde yapılan laboratuvar analizler sonucu, yamaç arazilerde yer alan topraklar, Soil Taksonomi sınıflandırmasına göre Lithic Ustorthent alt grubunda sınıflandıııırken, düz düze yakın eğimli taban ve tepe üstü/plato düzlüklerinde yer alan topraklar ise Typic Haplustert olarak sınıflandırılmıștır. Farklı toprak horizonlarının bazı topografik, fiziksel ve kimyasal özellikleri arasında korelasyon matrisleri belirlenmiștir. Ayrıca pedonlara ait genetik horizonların özellikleri arasında doğrusal regresyon modelleri olușturulmuștur. Çarpım, kare, kare kök içeren polinomlarla ifade edilen regresyon modellerinin regresyon katsayıları daha yüksek bulunmuștur.

Anahtar Kelimeler: Doğrusal regresyon model, toprak olușumu, bazalt ana materyal

\section{Determination of Liner Regression Model Between Some Topographic and Physico-chemical Properties of Soils Formed on Different Topographic Position and Basalt Parent Material}

\section{Abstract:}

The aim of this study is to investigate local variation of six soil pedons with time under different topographic position and land use-cover but over similar geologic material and to determine to generate liner regression models between slope, elevation and physico-chemical soil properties. In this concept, the main subjects in investigated six soil pedons that formed on basaltic parent material and different topographic positions and land use and land cover located in south of Samsun-Bafra highway and Engiz-Dağköy district were determine physical and chemical properties, and were classiffed. According to results which were obtained from both morphological properties in field study and analysis of soil samples in laboratory while soils located on high slope degree of transect were classified in Soil 
Taxonomy as Lithic Ustorthent, soils formed on almost flat land were classified as Typic Haplustert. In addition, it was created liner regresion models between genetic horizons of pedons

Key Words: Liner regresion model, soil formation, basalt parent matrial

\section{GíRiș}

Toprakların fiziksel ve kimyasal özellikleri, diğer çevresel faktörlerle beraber, toprak olușum süreçlerine, verimliliğe ve bitki gelișimine önemli düzeyde etki yapmaktadır. Fiziksel ve kimyasal özelliklerin değerleri ve değișimleri; toprakların katı, sıvı, gaz bileșenlerini ve oranlarını, bu bileșenlerin karșılıklı etkisini ve etkisel değișimlerini belirlemektedir. Dolayısıyla, toprakların fiziksel ve kimyasal özelliklerin belirlenmesi, verimliliğin korunması, tahmin edilmesi ve artırımasına yönelik yöntemlerinin belirlenmesinde gerekli olmaktadır.

Birçok araștırmacılar, toprakların fiziksel ve kimyasal özellikleri, strüktürel dayanaklılığı ve erozyona karșı duyarıı̆ı̆ı, bitki gelișiminde etkileyici faktörler olan tarla kapasitesi ve devamlı solma noktası değerlerini önemli șekilde etkilediğini belirtmișlerdir (Gülser vd., 2003; Gülser, 2004). Zaydelman (1987), toprakların infiltrasyon kapasitesi bünye ile yakından ilișkili olduğu için, kapalı dren aralıklarının toprakların bünye özelliğine göre belirlenebildiğini, dolayısıyla ağır bünyeli topraklarda dren aralıklarının az olması gerektiğini bildirmektedir. Ekberli ve Kerimova (2005; 2008), Azerbaycan'ın kurak iklime sahip Șirvan bölgesinin sulanan topraklarının bazı fiziksel ve kimyasal parametrelerinin değișimini; toprakların pH, değișebilir Na, bazı değișebilir bazik katyonların ( $\mathrm{Na}, \mathrm{Ca}, \mathrm{Mg}$ ) toplamı, humus ve $<0.001 \mathrm{~mm}$ fraksiyonları arasında fonksiyonel ilișkileri belirlemișlerdir. Araștırmacılar, toprakların fiziksel-kimyasal parametreleri arasındaki fonksiyonel ilișkilerin verimin tahmininde de kullanılmasının mümkün olduğunu bildirmișlerdir. Yine, Ekberli vd. (2009) tarafından Türkiye'nin Çankırı-Kızılırmak Havzasının alüviyal topraklarında yürütülen bir araștırmada, topraktaki tuz miktarı ile toprağın bazı fiziksel-kimyasal özellikleri arasındaki doğrusal ampirik ilișkiler belirlenmiștir. Elde edilen ampirik ilișkilerin, benzer özelliklere sahip bölge topraklarındaki tuz miktarının hesaplanmasında kullanılabilirliğini bildirmișlerdir.

Toprak ișleme süreçleri yöntemlerinin bilimsel temelinin belirlenmesinde, çeșitli topraklarda fiziksel ve kimyasal özelliklerin optimum değișim aralıklarının saptanması önemlidir. Zhumabekov (2005), toprakların plastiklik, yapıșkanlık, sıkılık, direnç gibi fiziksel-mekaniksel özelliklerinin tarım ișlemlerinde önemli olduğunu göstererek, Kırgızistan'ın temel toprak tiplerinde, bu özelliklerin toprak nemine bağı olarak değișimini incelemiștir. Toprak neminin \%15.8-42.3 arasında değișiminde, plastiklik sayısının 4.1-15.9; nemin \% 11 .2-30.6 arasında değișiminde iseyapıșkanlığın 6.9-40.5 g/ $\mathrm{cm}^{2}$ arasında değiștiğini bildirmiștir. Mısır bitkisi altındaki sulanan ve sulanmayan toprakların \%15.3-24.6 nem durumunda, direncin $0.50-0.65 \mathrm{~kg} \mathrm{~cm}^{-2}$ arasında olduğunu göstermiștir. Utkaeva (2007) tarafından, podzolik, allüvüyal, gri orman, çernezyom (tipik, yıkanmıș, vertik), solonetzic topraklarının fiziksel özellikleri değerlendirilmiș ve çeșitli antropojen etkiler sonucunda humus, nem, su tutma kapasitesi vb. gibi özelliklerin değișimi incelenmiștir. Çeșitli ıslah yöntemleri kullanılarak, toprakların optimum su bilançosunun yapılmasında da fiziksel özelliklerin belirlenmesi gereklidir. Korolev (2008), çernezyem topraklarda yapılan bir araștırmada sulama sonucunda toprağın temel fiziksel özelliklerinin değișimini incelemiștir. Sulama sonucunda, toprağın yukarı horizonlarında kil ve 0.01 mm'den küçük zerreciklerde azalma eğiliminin olduğunu; strüktürün düșük ve orta düzeyde, özgül ağırlık, toplam mesamelik ve hava tutumunun düșük düzeyde bozulduğunu göstermiștir. Purtova ve Zimina (2007) tarafindan yapılan bir araștırmada, kahverengi orman topraklarının yüzey horizonlarında (fitogenik alanlarda) fiziksel-kimyasal özelliklerin değișimi ve özellikler arasındaki ilișkiler belirlenmiștir. Fitogenik alanlarda humus miktarının (\%3.42-15.27) ve rezervinin (0-20 cm katmanında 72.0-228.0 t ha') yüksek, pH değerlerinin ise (2.74-6.16) düșük öldüğünü göstermișlerdir.

Toprak özellikleri arasındaki ampirik modeller, deneysel olarak elde edilen parametrelerin karșılıklı etkisini göz önüne alarak yapılmaktadır. Olayın mahiyetine varmadan sebep $\left(\mathrm{x}_{1}, i=1, \mathrm{n}\right) \rightarrow$ sonuç $(y)$ ilișkisini $(y=f(x))$ belirlemekte ve 
uygulamaya yönelik özelliğe sahip olmaktadır. Araștırılan ekosistemin (toprağın) özelliklerini ifade eden basit matematiksel ilișkilerin yapılmasına imkan veren parametrelerin nispeten az sayıda bulunması, regresyon modellerinin yapılmasının temel kısmı olmaktadır. Regresyon modellerine dâhil olan parametrelerin fazla olması (>20-30) modellerin uygulanabilirliğini zorlaștırmaktadır. Yukselen-Aksoy ve Kaya (2010), toprakların fiziksel ve kimyasal özellikleriyle, özgül yüzey alanı arasındaki ilișkilerin belirlenmesinde regresyon denklemlerinden kullanılmıșlardır. Elde edilen denklemlerin, benzer fiziksel ve kimyasal özelliklere sahip topraklarda kalibre edilmesinin gerekliliğini bildirmișlerdir. Simon ve Garcia (1999) tarafından yapılan bir çalıșmada, toplam çözünür tuzlarla (S), EC değerleri arasındaki ilișki ikinci dereceden regresyon denklemle $\mathrm{S}=28.320 \mathrm{EC}+0.2858$ $E C^{2}, r=0.969$, RMS $\left.=61.5\right)$ ifade edilmiștir. Azerbaycan'ın Mil ovası topraklarının verimlilik düzeylerinin deneysel ve matematiksel olarak değerlendirilmesinde, agroekolojik, agrofiziksel ve agrokimyasal özellikleri kapsayan kavramsal modeller olușturulmuș, bu özelliklerle verimlilik arasındaki ilișkiler çok değișkenli doğrusal regresyon denklemler ile ifade edilmiștir (Bayraklı vd., 1999). Candemir ve Gülser (2012) yaptıkları bir araștırmada, alkali toprakların su iletkenliğine etki yapan faktörleri belirleyerek, su iletkenliğinin tahmininde birinci ve ikinci derecedendoğrusal regresyon denklemleri kullanılmıșlardır. Topraklarda doygun hidrolik iletkenliğin tahmininde de birinci ve ikinci dereceden pedotransfer ilișkilerin kullanılması mümkün olmaktadır (Gülser vd., 2007). Bir çok araștırmacılar (Oian vd., 1996; Li vd., 1998; Carlona vd., 2004; Verachtert vd., 2011 ; Liu vd., 2014; Bosch vd., 2016; Silva Chagas vd., 2016) tarafından toprak parametrelerinin karșilıklı etkisine bağlı olarak çeșitli regresyon ilișkiler (doğrusal ve doğrusal olmayan) yapılmakta ve tahmin süreçlerinde kullanılmaktadır.

Bu araștırmada, farklı topografik pozisyonlarda ve aynı ana materyal (bazalt) üzerinde olușmuș toprakların genetik horizonlarına ait bazı fiziksel ve kimyasal özelliklerinin belirlenmesi; eğim ve yükselti gibi topografik parametrelerle fiziksel ve kimyasal toprak özelliklerinin karșılıklı etkisini ifade eden korelasyon matrisinin olușturulması; karșıılıkı etkisi önemli olan özellikler arasında doğrusal regresyon modellerinin belirlenmesi hedeflenmiștir.

\section{MATERYAL ve YÖNTEM}

Araștırma sahası Engiz Çayı havzası içerisindedir. Engiz Çayı Havzası Karadeniz Bölgesi'nin Orta Karadeniz bölümünde, Bafra Ovasının kuzeyinde, Samsun ili sınırları içerisinde yer alır. Dağköy mevkii alanı içerisinde deniz seviyesinden 20 m ile 300 m arasında yükselti değișkenliğinde bulunmaktadır. Araștırma sahası ve yakın çevresinde yüzeylenen en geniș birim Yenikonak formasyonudur. Volkano sedimanter kayaçlardan olușmaktadır. Büyük çoğunluğu tüf, tüfit, bazalt, kumlu kireçtașı ve marn ara seviyeli kumtașı-șeyl ardalanmasından olușmaktadır. Dikkate alınan bazalt ana materyali üzerinde olușan topraklarda mera alanları ile kuru tarım yapılan alanlar yer almakta olup çok az olsa da meșelerden olușan ormanlık alanlar mevcuttur. Mera alanlarında yaygın olan bașlıca otsu familyalar șunlardır; lahanagiller (Cruciferae), buğdaygiller (Gramineae), maydonozgiller (Umbelliferae), papatyagiller (Compositae), baklagiller (Fabaceae), gülgiller (Rosaceae). Kuru tarım yapılan alanlarda da çoğunlukla buğday tarımı yapılmaktadır.

Araștırma sahası içerisinde ölçüm istasyonu bulunmamaktadır. Bu yüzden saha çevresindeki istasyonlar esas alınmıștır. Araștırma sahasında yılın en soğuk ayı Șubat'tır $\left(5.6^{\circ} \mathrm{C}\right)$. En sıcak aylar ise Temmuz ve Ağustos aylarıdır $\left(22.6^{\circ} \mathrm{C}\right)$. Yılın dört ayında (Aralık, Ocak, Șubat, Mart) ortalama sıcaklıklar $10^{\circ} \mathrm{C}$ 'nin altında kalırken Nisan ayından itibaren yükselmektedir. Illkbahar dönemlerinde düzenli bir sıcaklık artıșı ve sonbahar dönemlerinde düzenli bir azalma görülmektedir (Çizelge 1). Araștırma sahasında ortalama yağıș miktarı yaklașık 800 mm'lerde değișir. Uzun yıllar aylık yağıș ortalamaları ise en düșük Temmuz 130.9 $\mathrm{mm}$ ) ve Ağustos (42.2 mm) en yüksek ekim ise Ekim $(101.6 \mathrm{~mm})$ aylarındadır. Yaz aylarının bitimiyle Eylül ayında artan yağıș miktarı Ekim ayında belirgin șekilde yükselmektedir. Yağıșın mevsimlere göre dağılıșı incelendiğinde en fazla yağıșın sonbahar mevsiminde en az yağıșın ise yazın düștüğü görülmektedir. Buna göre çok düzenli olmasa da yağıșların bütün yıla dağıldığını söylemek mümkündür.

Buharlașma eğrisi Nisan ayı ortalarından Eylül ayının sonlarına kadar yağıș eğrisinden yüksektir. Nisan sonlarından Haziran sonlarına kadar birikmiș su kullanılmıștır. Bu yüzden bu aylarda kuraklık etkili değildir. Temmuz ayından itibaren Eylül 


\section{toprâj}

Çizelge 1. Bafra'nın uzun yıllar (1975-2010) ortalama aylık yağıș ve sıcaklık dağııımı

Table 1. Long term (1975-2010) mean month precipitation and tempereture distribution of Bafra

\begin{tabular}{llllllllllllll}
\hline Aylar & $\mathrm{O}$ & $\mathrm{S}$ & $\mathrm{M}$ & $\mathrm{N}$ & $\mathrm{M}$ & $\mathrm{H}$ & $\mathrm{T}$ & $\mathrm{A}$ & $\mathrm{E}$ & $\mathrm{E}$ & $\mathrm{K}$ & $\mathrm{A}$ & $\mathrm{Y}$ Illık \\
\hline $\mathrm{T}$ & 5.7 & 5.6 & 7.2 & 10.9 & 15.1 & 19.8 & 22.6 & 22.6 & 19.0 & 14.9 & 11.0 & 7.6 & 13.5 \\
$\mathrm{P}$ & 81.6 & 65.7 & 60.3 & 56.9 & 47.8 & 48.3 & 30.9 & 42.2 & 61.3 & 101.6 & 98.3 & 100.6 & 794.4 \\
\hline
\end{tabular}

T: Sıcaklık $\left({ }^{\circ} \mathrm{C}\right), \mathrm{P}:$ Yağıș Ortalaması $(\mathrm{mm})$

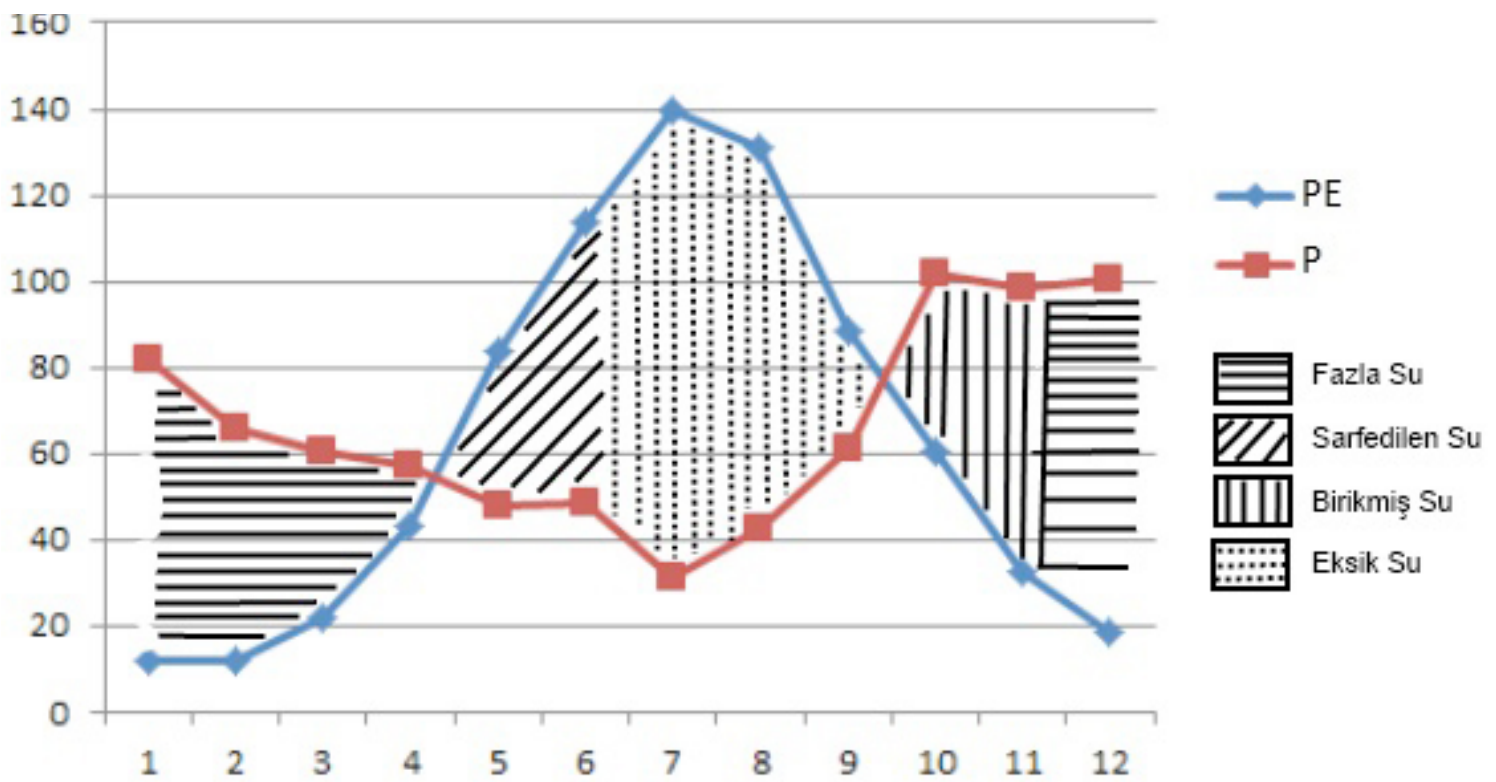

Șekil 1. Bafra'nın su bilançosu diyagramı (Thornthwaite, 1948)

Figure 1. Soil water budged of Bafra (Thornthwaite, 1948)

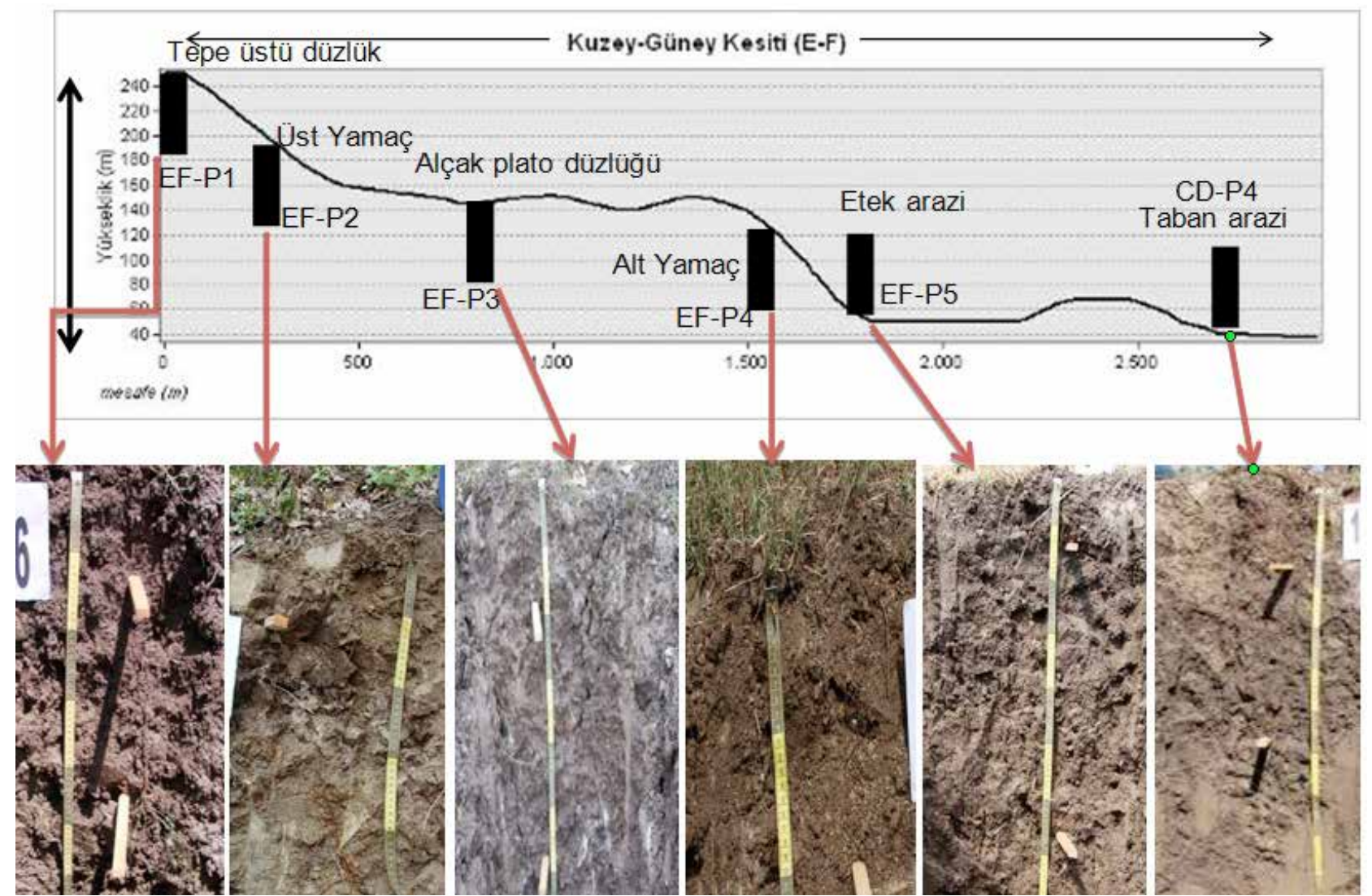

Șekil 2. Kuzey-Güney kesiti üzerinde yer alan farklı topografik pozisyonda açılan profiller

Figure 2. Soil profiles located on different topographic position at North and South transect

18 
ayının ortalarına kadar yaklașık üç buçuk aylık bir süre kurak geçmektedir (Șekil 1). Araștırma sahası iklim verileri De Martonne formülü kullanılarak değerlendirilmiștir. Bu formüle göre sahanın yıllık indis değeri 33.8'dir. Bu değere göre saha nemli iklim sahası içerisinde kalmaktadır. Araștırma sahası Köppen'e göre Orta İklimler Kușağı'nda yer alır.

Araștırma sahası toprakları deniz seviyesinden 20 m ile 300 m arasında yükselti değișkenliği içerisindeki farklı topografik pozisyonlarda (tepe üstü düzlük, yamaç, taban vb. araziler) yer alan bazaltik ana materyal üzerinde olușmaktadır. Kuzey-Güney doğrultusu üzerinde yer aldığı çalıșma alanı yaklașık $9.5 \mathrm{~km}^{2}$ olup, kesitleri üzerindeki arazi șekil ve açılan profillerin șematik gösterimi Șekil 2' de verilmiștir.

Arazide yapılan ön arazi keșif çalıșması yanı sıra alanda farklı topografya ve bazalt ana materyal üzerinde olușmuș farklı toprak yerleri sayısal topografik harita üzerine koordinatları aktarılmıștır. Arazide daha önce ön arazi keșfi ve büro çalıșmalarıyla belirlen profil çukur yerleri arazide GPS aleti kullanılarak yerleri belirlenmiș ve bu noktalarda profil çukurları açılmıștır. Açılan her bir profil çukurundan (1.5-2 m) horizon esasına göre toprak örneklemeleri yapılarak laboratuvara getirilmiș ve analiz ön ișlemlerine tabi tutulmuștur. Analizlere hazır hale getirilen topraklarda fiziksel ve kimyasal analizler yapılmıștır. Morfolojik çalıșmalarda Soil Survey Staff (1993)' den yararlanılmıștır. Toprakların morfolojik tanımlamaları için açılan her profil Soil Survey Staff (1993) tarafından belirtilen usuller esas alınarak incelenmiștir. Horizonların tanımı ve adlandırılması ise Soil Survey Staff (1 999)'a göre yapılmıștır.

Bünye (tekstür) bozulmuș toprak örneklerinde (Bouyoucous 1951), değișebilir katyonlar pH' sı 8.2'ye ayarlı sodyum asetat (NaOAc) kullanılarak (Rhoades, 1986), kireç serbest karbonatların tayininde Scheibler kalsimetresi kullanılarak (Soil Survey Staff, 1993), toprak reaksiyonu $(\mathrm{pH})$ saturasyon çamurunda $\mathrm{pH}$ metre kullanılarak (Soil Survey Staff, 1992; 2004), elektriksel iletkenlik saturasyon çamurunda kondaktivimetre aleti kullanılarak (Soil Survey Staff , 1992; 2004), organik madde Walkley-Black yönteminin Jackson tarafından modifiye edilmiș șekli ile yapılmıștır (Jackson, 1958).

Topraklarının bazı fiziksel-kimyasal özellikleri arasındaki doğrusal regresyon denklemlerinin belirlenmesinde $y=a_{0}+a_{1} x_{1}+a_{2} x_{2}+\ldots a_{n} x_{n} \quad$ (burada, $a_{0}, a_{1}, a_{2}, \ldots, a_{n}$ en küçük kareler yöntemiyle belirlenmesi gereken katsayılar; $y$-bağımlı; $x_{1}(i=\overline{1, n})$-bağımsız parametrelerdir) biçimindeki fonksiyonlardan kullanılmıștır. Modellerin olușturulmasında toprak özellikleri arasındaki korelasyon ilișkiler dikkate alınmıștır. Toprak Özelliklerinin bir birine karșılıklı etkisini göz önüne alarak, Özelliklerin çarpımını ve kare kökünü içeren terimlerden kullanılmıștır. Bağımlı değișken olarak pH, KDK, OM, kil, kireç değerleri alınmıș ve toprak özellikleri ile olan çoklu regresyon ilișkileri MiNiTAB-32 bilgisayar programını kullanılarak olușturulmuștur.

\section{BULGULAR ve TARTIȘMA}

\section{Toprakların Bazı Fiziksel, Kimyasal Özellikleri ve Sınıflaması}

Kuzey-Güney doğrultusunda yer alan farklı topografik pozisyonda (tepe üstü düzlük, üst yamaç, alçak plato düzlüğü, etek ve taban) ve arazi kullanımlarında (tarım, orman ve mera) açılan altı farklı profile ait fiziksel ve kimyasal analiz sonuçları Çizelge 2' de verilmiștir.

Typic Haplustert olarak sınıflandırılan CD-P4 nolu profili, taban arazi üzerinde olușmuș düz düze yakın eğimli, derin topraklardır. Tüm profil kil bünyeli olup, kil \% 56.2 ile \% 78.2 arasında değișmektedir. Bu durum toprakların saturasyon durumlarını doğrudan etkilemeleri nedeniyle özellikle kil miktarının derinlikle artıșı, toprakların sature olma durumlarını da arttırmaktadır. KDK'ları yüzeyde $42.80 \mathrm{cmolkg}^{-1}$ olmasına karșın derinlere doğru bu miktar düșüș göstermekte ve 39.78 cmol. $\mathrm{kg}^{-1}$ olmaktadır. Bu azalma kil miktarındaki bir miktar artmasına karșın, organik kökenli kollaidal maddelerin azalmasından kaynakladığı söylenebilir. Organik madde miktarı ise yüzeyde \% 1.65 olmasına karșın $65 \mathrm{~cm}$ den sonra daha da azalarak \% 0.14'e düșmektedir. Toprak reaksiyon hafif bazik olup pH değerleri 7.05 ile 8.25 arasında değișmektedir. Kireç profilde çok az miktarda olup yüzeyde \% 0.20 iken derinde bir miktar artarak \% 2.67 olmaktadır. Topraklarda baskın değișebilir katyonlar Ca ve Mg iyonlarıdır. Topraklarda tuzluluk ve alkalilik problemi görülmemektedir.

Etek arazi üzerinde açılan ve Vertic Haplustept olarak sınıflandırılan EF-P5 kodlu toprak profili, orta derin ve ağır bünyelidir. 66 cm derinliğe kadar kil \%58.3 ile \%61. 9 arasında değișmektedir. KDK'ları yüzeyde organik madde miktarı ve kil 
içeriği nedeniyle $43.70 \mathrm{cmolkg}^{-1}$ olmasına karșın 66 cm'den sonra $22.77 \mathrm{cmol}^{\mathrm{kg}}{ }^{-1}$ düșmektedir. Benzer șekilde organik madde miktarı içinde geçerli olup yüzeyde \% 2.21 olmasına karșın yüzey altı katmanda $\% 0.55^{\prime}$ e düșmektedir. Toprak reaksiyon bazik olup $\mathrm{pH}$ değerleri 8.12 ile 8.28 arasında değișmektedir. Kireç profilde çok az miktardadır ve \%0.79-1.75 arasında değișmektedir. Topraklarda baskın değișebilir katyonlar Ca ve $\mathrm{Mg}$ iyonlarıdır. Topraklarda tuzluluk ve alkalilik problemi görülmemektedir.

EF-P4 kodlu profil Kuzey-Güney doğrultusunda yer alan kesiti üzerinde deniz seviyesinden 135 m yükseklikte yer alan profil olup, Lithic Ustorthent olarak sınıflandırılmıștır. Profilin bulunduğu alan fizyografik açıdan yamaç arazidir. Yüzey örtüsü çok zayıf olması ve dik eğimli olmaları nedeniyle erozyon siddeti fazla, bu nedenle topraklar cok sığ $(19 \mathrm{~cm})$ derinliğe sahiptirler. Yüzey toprakları orta bünyeli olup kumlu kil tındır. KDK ve organik madde içerikleri yüzey toprağında $4185 \mathrm{cmol}$. kg-1 ve \% 3.37 dir. Toprak reaksiyonu hafif alkalin olup, pH değerleri 7.89' dir. Kireç profilde çok az olup \%0.39'dur. Topraklarda baskın değișebilir katyonlar Ca ve Mg iyonlarıdır. Topraklarda tuzluluk ve alkalilik problemi görülmemektedir.

Çizelge 2. Çalıșma toprakların fiziksel ve kimyasal analiz sonuçları, yükselti ve arazi kullanım durumları

Table 2. Physical and chemical analysis results of studied soils and their elevation and land use

\begin{tabular}{|c|c|c|c|c|c|c|c|c|c|c|c|c|c|}
\hline \multirow[t]{2}{*}{ Horizon } & \multirow[t]{2}{*}{$\begin{array}{l}\text { Derinlik } \\
\text { (cm) }\end{array}$} & \multirow[t]{2}{*}{$\mathrm{pH}$} & \multirow[t]{2}{*}{$\begin{array}{c}\mathrm{EC} \\
\mathrm{dS} \cdot \mathrm{m}^{-1}\end{array}$} & \multirow[t]{2}{*}{$\begin{array}{c}\text { Kireç } \\
\%\end{array}$} & \multirow[t]{2}{*}{$\begin{array}{l}\mathrm{OM} \\
\%\end{array}$} & \multirow[t]{2}{*}{$\begin{array}{c}\text { KDK } \\
\mathrm{cmol} . \mathrm{kg}^{-1}\end{array}$} & \multicolumn{3}{|c|}{$\begin{array}{l}\text { Değișebilirler Katyonlar } \\
\mathrm{cmol} \mathrm{kg}^{-1}\end{array}$} & \multicolumn{4}{|c|}{$\begin{array}{l}\text { Bünye Dağılımı } \\
\%\end{array}$} \\
\hline & & & & & & & $\mathrm{Na}+$ & $\mathrm{K}+$ & $\mathrm{Ca}+++\mathrm{Mg}++$ & Kil & Silt & Kum & Sinıf \\
\hline \multicolumn{14}{|c|}{ CD-P4 / Taban / Kuru Tarım / 25 m } \\
\hline$A$ & $0-23$ & 7.50 & 0.17 & 0.20 & 1.65 & 42.80 & 0.22 & 1.67 & 40.91 & 56.2 & 23.1 & 20.7 & C \\
\hline Bss 1 & $23-65$ & 7.30 & 0.44 & 0.98 & 1.26 & 41.36 & 0.25 & 1.47 & 39.64 & 62.6 & 12.8 & 24.5 & C \\
\hline Bss2 & $65-106$ & 8.25 & 0.17 & 1.10 & 1.09 & 40.33 & 1.33 & 1.41 & 37.59 & 68.4 & 15.8 & 15.8 & C \\
\hline$C$ & $106+$ & 8.14 & 0.11 & 2.67 & 0.14 & 39.78 & 1.35 & 1.40 & 36.04 & 78.4 & 2.8 & 18.8 & $C$ \\
\hline
\end{tabular}

EF5 / Etek / Orman / 42 m

\begin{tabular}{|c|c|c|c|c|c|c|c|c|c|c|c|c|c|}
\hline A & $0-15$ & 8.28 & 0.26 & 0.79 & 2.21 & 43.70 & 0.36 & 0.36 & 42.97 & 58.3 & 20.0 & 21.7 & C \\
\hline $\mathrm{Bw}$ & $15-66$ & 8.12 & 0.18 & 1.26 & 0.67 & 43.37 & 0.47 & 0.32 & 42.58 & 61.9 & 25.6 & 12.5 & C \\
\hline $2 \mathrm{Cr}$ & $66-106$ & 8.20 & 0.25 & 1.75 & 0.55 & 27.77 & 1.02 & 0.26 & 26.49 & 37.3 & 34.8 & 27.9 & CL \\
\hline
\end{tabular}

EF-P4 /Alt Yamaç / Kuru tarım / 135 m

\begin{tabular}{|c|c|c|c|c|c|c|c|c|c|c|c|c|c|}
\hline$A$ & $0-19$ & 7.89 & 0.40 & 0.39 & 3.37 & 41.85 & 0.16 & 0.49 & 41.02 & 32.5 & 18.6 & 48.9 & SCL \\
\hline $\mathrm{R}$ & $19-32$ & - & - & - & - & & - & - & - & - & - & - & - \\
\hline
\end{tabular}

EF-P3 / Alçak plato düzlüğü / Orman / 160 m

\begin{tabular}{|c|c|c|c|c|c|c|c|c|c|c|c|c|c|}
\hline$A$ & $0-18$ & 7.06 & 0.44 & 1.08 & 1.88 & 47.28 & 0.24 & 0.32 & 46.71 & 54.4 & 22.6 & 23.1 & $C$ \\
\hline Bw & $18-57$ & 7.31 & 0.42 & 1.02 & 0.06 & 50.54 & 0.34 & 0.09 & 50.11 & 61.1 & 17.7 & 21.2 & $C$ \\
\hline $\mathrm{Cr}$ & $57-87$ & 7.01 & 0.51 & 0.39 & 0.57 & 40.54 & 0.58 & 0.09 & 39.87 & 57.5 & 22.6 & 19.9 & C \\
\hline \multicolumn{14}{|c|}{ EF-P2 / Üst Yamaç / Orman/ 190 m } \\
\hline$A$ & $0-11$ & 6,74 & 0.35 & 0.09 & 1.54 & 28.70 & 0.35 & 0.43 & 27.92 & 22.0 & 21.8 & 56.2 & $S L$ \\
\hline $\mathrm{Cr}$ & $11-65$ & 7.01 & 0.20 & 0.29 & 0.87 & 17.66 & 0.54 & 0.12 & 17.00 & 14.6 & 9.3 & 76.1 & LS \\
\hline \multicolumn{14}{|c|}{ EF-P1/Tepe üstü düzlük / Mera / 251 m } \\
\hline A & $0-12$ & 7.14 & 0.55 & 0.69 & 3.53 & 49.73 & 0.29 & 0.58 & 48.85 & 61.9 & 23.6 & 14.5 & C \\
\hline Bw1 & $12-41$ & 7.70 & 0.54 & 0.98 & 1.78 & 44.57 & 0.27 & 0.31 & 43.98 & 49.9 & 27.7 & 12.5 & C \\
\hline Bw2 & $41-84$ & 7.92 & 0.11 & 0.98 & 1.41 & 52.55 & 0.64 & 0.29 & 51.62 & 47.9 & 32.3 & 19.8 & $C$ \\
\hline $2 \mathrm{Ck}$ & 84-105 & 7.94 & 0.38 & 6.37 & 1.29 & 44.46 & 0.63 & 0.09 & 43.74 & 40.0 & 40.8 & 19.1 & C \\
\hline
\end{tabular}

EC: Elektiriksel iletkenlik, OM: Organik madde 
Typic Haplustept olarak sınıflandırılan EF-P3 kodlu profil, deniz seviyesinden 160 m yükseklikte yer alan alçak plato üzerinde olușmuș, hafif eğime sahip derin topraklardır. Üzerinde genellikle orman ve mera örtüsü bulunduran bu arazilerdeki topraklar, ağır bünyelidirler. Kil profilde \%54.4 ile \%61.1 arasında değișmektedir. Bu durum ağır bünyeye sahip profillerde olduğu gibi, toprakların doygunluk olma durumlarını doğrudan etkilemeleri nedeniyle özellikle kil miktarının derinlikle artıșı, toprakların suyla doygun olma durumlarını da arttırmaktadır. KDK'ları 40.54 ile $50.54 \mathrm{cmolkg}^{-1}$ arasında değișmektedir. Organik madde miktarı yüzeyde \% 1.88 iken derinlere doğru bu oran hızlı bir șekilde düșmektedir. Toprak reaksiyonu hafif bazik olup $\mathrm{pH}$ değerleri 7.01 ile 7.31 arasında değișmektedir. Kireç profilde çok az miktarda olup, yüzeyde \%0.39 iken derinde bir miktar artarak \% 1.08 olmaktadır. Topraklarda baskın değișebilir katyonlar Ca ve Mg iyonlarıdır. Topraklarda tuzluluk ve alkalilik problemi görülmemektedir.

Lithic Ustorthent olarak sınıflandırılan EF-P2 kodlu profil Kuzey-Güney doğrultusunda yer alan kesiti üzerinde deniz seviyesinden 190 m yükseklikte olup, fizyografik arazi șekli yamaçtır. Çok sığ derinliğe $(11 \mathrm{~cm})$ sahip, kumlu tın bünyelidirler. Kil ve organik madde içerikleri diğer profillere göre çok düșük seviyelerde olmaları nedeniyle KDK 17.66 ile $28.70 \mathrm{cmolkg}^{-1}$ arasında değișmektedir. Toprak reaksiyonu, hafif asit ile nötür olup, pH değerleri 6.74 ile 7.01 arasında değișmektedir. Kireç profilde çok az olup \%0.09 ile \%0.29 arasındadır. Topraklarda baskın değișebilir katyonlar Ca ve $\mathrm{Mg}$ iyonlarıdır. Topraklarda tuzluluk ve alkalilik problemi görülmemektedir.

EF-P1 kodlu profil Kuzey-Güney kesiti üzerinde deniz seviyesinden $251 \mathrm{~m}$ ile en yüksekte yer alan profil olup Typic Haplustept olarak sınıflandırıımıștır. Tepe üstü düzlükler üzerinde yer alan arazilerde yayılım göstermektedirler. Tüm profil kil bünyeli olup, kil \%40.0 ile \%61.9 arasında değișmektedir. Bu durum toprakların doygun olma durumlarını doğrudan etkilemeleri nedeniyle özellikle kil miktarının derinlikle artıșı, toprakların sature olma durumlarını da arttırmaktadır. KDK'ları yüksek kil içeriği nedeniyle 44.46 ile $52.55 \mathrm{cmolkg}^{-1}$ arasında değișmektedir. Toprak reaksiyon hafif bazik olup pH değerleri 7.14 ile 7.94 arasında değișmektedir. Kireç profilde az miktarda olup yüzeyde \% 0.69 iken derinde bir miktar artarak \%4.37 olmaktadır.
Topraklarda baskın değișebilir katyonlar Ca ve Mg iyonlarıdır. Topraklarda tuzluluk ve alkalilik problemi görülmemektedir.

\section{Farklı Toprak Horizonlarının Bazı Topografik, Fiziksel ve Kimyasal Özellikleri Arasındaki îlișkiler}

Araștırma toprağının A horizonlarının özellikleri arasındaki ilișkilere ait korelasyon katsayıları Çizelge 3'de verilmiștir. Kesit üzerinde yer alan toprakların $\mathrm{pH}$ değerleri ile silt ve yükseklik arasında yüksek negatif korelasyonlar, diğer özellikleri arasında ise zayıf ve çok zayıf ilișkiler bulunmuștur. $\mathrm{pH}$ değerlerinin sayısal olarak dar aralıkta (6.74-8.28) değișimi, diğer özelliklerin ise (örneğin Na, K, silt, kum) çok düșük değerlere sahip olması, korelasyon katsayılarının düșük olmasının nedenlerinden olabilmektedir. Yükseklik artıkça, atmosfer olaylarının (özellikle yağıș miktarı, çeșidi vb.) daha etkili olması sonucu, toprağın pH değerlerinin azalması mümkün olabilir. Toprağın EC değerleri, yükseklik ile çok önemli düzeyde pozitif ilișki vermiș, $\mathrm{OM}$ ve $\mathrm{K}$ ile ise korelasyon ilișki yüksek, fakat önemli düzeyde olmamaktadır. Kireç, OM, Na, K, silt miktarları geri kalan toprak özellikleriyle önemsiz düzeyde ilișki göstermiștir. Kireç ile KDK, Ca+Mg, kil ve kum arasında yüksek korelasyon, eğim ile ise orta șiddette negatif ilișki saptanmıștır. Toprak KDK' sı, Ca+Mg ile çok önemli pozitif, kil ile önemli pozitif, kum ile önemli düzeyde negatif, eğim ile ise orta șiddette negatif ilișkiler vermiștir. Ca+Mg ile kil ve kum miktarları arasında önemli düzeyde sırasıyla pozitif ve negatif, eğim ile ise orta șiddette negatif ilișkiler belirlenmiștir. Kil miktarı kum ile çok önemli, eğim ile ise önemli düzeyde negatif ilișkiler göstermiștir. Kum miktarıyla eğim arasındaki ilișki pozitif ve önemli bulunmuștur.

Kesit üzerinde yer alan toprakların B horizonlarının özellikleri arasındaki ilișkilere ait korelasyon katsayıları Çizelge 4'de gösterilmiștir. Toprakların $\mathrm{pH}$ değerleri ile EC, kireç, Na ve kum arasındaki korelasyon katsayılar yüksek olup, fakat önemli olmamaktadır. EC değeri diğer tüm toprak özellikleriyle, zayıf ilișkiler göstermiștir. Kireç ve OM ile diğer toprak parametreleri arasında zayıf ve orta șiddette korelasyonlar bulunmuștur. Kireç ile eğim arasında ise önemli düzeyde pozitif ilișki saptanmıștır. KDK ile Ca+Mg arasında çok önemli düzeyde pozitif ilișki, diğer parametreler arasında ise zayıf ve orta șiddette korelasyonlar 
Çizelge 3. A horizonlarına ait toprak parametrelerine ilișkin korelasyon matrisi

Table 3. Correlation matris of soil parametres for A horizons of soils

\begin{tabular}{|c|c|c|c|c|c|c|c|c|c|c|c|c|}
\hline & EC & Kireç & $\mathrm{OM}$ & KDK & $\mathrm{Na}$ & $\mathrm{K}$ & $\mathrm{Ca}+\mathrm{Mg}$ & Kil & Silt & Kum & Yükseklik & Eğim \\
\hline $\mathrm{pH}$ & -0.410 & 0.173 & 0.277 & 0.306 & -0.123 & 0.031 & 0.278 & 0.296 & -0.671 & -0.204 & -0.659 & 0.120 \\
\hline EC & & 0.431 & 0.651 & 0.345 & -0.063 & -0.606 & 0.376 & 0.019 & 0.163 & -0.036 & $0.922^{* *}$ & 0.089 \\
\hline Kireç & & & 0.204 & 0.735 & 0.046 & -0.500 & 0.778 & 0.628 & 0.079 & -0.601 & 0.138 & -0.455 \\
\hline OM & & & & 0.514 & -0.343 & -0.261 & 0.497 & 0.162 & -0.255 & -0.125 & 0.454 & 0.275 \\
\hline KDK & & & & & -0.329 & 0.054 & 0.997 ** & $0.865^{*}$ & 0.239 & $-0.843^{*}$ & 0.021 & -0.543 \\
\hline $\mathrm{Na}$ & & & & & & -0.344 & -0.269 & 0.036 & 0.181 & -0.055 & 0.115 & -0.305 \\
\hline K & & & & & & & -0.003 & 0.251 & 0.394 & -0.283 & -0.531 & -0.329 \\
\hline $\mathrm{Ca}+\mathrm{Mg}$ & & & & & & & & $0.872^{*}$ & 0.258 & $-0.852^{*}$ & 0.056 & -0.568 \\
\hline Kil & & & & & & & & & 0.452 & $-0.995^{* *}$ & -0.207 & -0.848 * \\
\hline Silt & & & & & & & & & & -0.539 & 0.288 & -0.773 \\
\hline Kum & & & & & & & & & & & 0.163 & 0.887 * \\
\hline Yükseklik & & & & & & & & & & & & 0.138 \\
\hline
\end{tabular}

** Korelasyon 0.01 düzeyinde çok önemli; *Korelasyon 0.05 düzeyinde önemli

belirlenmiștir. KDK ve yükseklikle yüksek pozitif ilișki belirlenmiștir. Na ile diğer özellikler arasındaki ilișkiler önemsiz olarak saptanmıștır. K değerleri, $\mathrm{Ca}+\mathrm{Mg}$ ile önemli negatif, yükseklik ve eğimle ise sırasıyla yüksek ve orta șiddette negatif korelasyonlar vermiștir. Kil miktarı silt ile önemli, yükseklikle ise çok önemli düzeyde negatif ilișkiler göstermiștir. Kum miktarının diğer tüm toprak özellikleriyle ilișkileri önemsiz düzeyde olup, pH'la yüksek, kireç, silt ve eğim ile orta șiddette negatif korelasyonlar vermiștir.
Araștırma topraklarının ana materyallerine yönelik incelenen değișkenlerine ilișkin korelasyon matrisi Çizelge 5'de verilmiștir. Çizelgeden de görüldüğü gibi, toprağın pH değeriyle, diğer tüm özellikleri arasındaki ilișkilerinin önemsiz olmasına rağmen, Na ile yüksek șiddette pozitif, kireç ve K ile orta șiddette pozitif, kum, yükseklik ve eğim ile ise orta șiddette negatif korelasyonlar saptanmıștır. Toprağın EC değerleriyle, kireç, kil, kum, eğim arasında zayıf; diğer özellikleriyle ise orta ve yüksek șiddette korelasyonlar bulunmuștur. Kireç

Çizelge 4. B horizonlarına ait toprak parametrelerine ilișkin korelasyon matrisi

Table 4. Correlation matris of soil parametres for B horizons of soils

\begin{tabular}{|c|c|c|c|c|c|c|c|c|c|c|c|c|}
\hline & EC & Kireç & $\mathrm{OM}$ & KDK & $\mathrm{Na}$ & K & $\mathrm{Ca}+\mathrm{Mg}$ & Kil & Silt & Kum & Yükseklik & Eğim \\
\hline $\mathrm{pH}$ & -0.754 & 0.617 & 0.201 & -0.246 & 0.749 & 0.073 & -0.282 & 0.114 & 0.371 & -0.693 & -0.152 & 0.285 \\
\hline EC & & -0.492 & 0.108 & -0.137 & -0.669 & -0.045 & -0.068 & -0.122 & -0.296 & 0.136 & 0.191 & -0.265 \\
\hline Kireç & & & -0.412 & -0.358 & 0.276 & -0.066 & -0.331 & 0.491 & 0.023 & -0.567 & -0.538 & $0.818^{*}$ \\
\hline OM & & & & -0.225 & 0.028 & 0.269 & -0.232 & -0.525 & 0.370 & -0.214 & 0.324 & -0.458 \\
\hline KDK & & & & & -0.273 & -0.755 & $0.993 * *$ & -0.647 & 0.566 & 0.245 & 0.755 & 0.069 \\
\hline $\mathrm{Na}$ & & & & & & 0.437 & -0.364 & 0.436 & -0.136 & -0.219 & -0.331 & -0.237 \\
\hline K & & & & & & & $-0.814^{*}$ & 0.608 & -0.704 & 0.322 & -0.719 & -0.543 \\
\hline $\mathrm{Ca}+\mathrm{Mg}$ & & & & & & & & -0.674 & 0.591 & 0.199 & 0.775 & 0.139 \\
\hline Kil & & & & & & & & & $-0.837 *$ & 0.117 & -0.921 ** & 0.056 \\
\hline Silt & & & & & & & & & & -0.492 & 0.757 & 0.338 \\
\hline Kum & & & & & & & & & & & -0.139 & -0.497 \\
\hline Yükseklik & & & & & & & & & & & & -0.121 \\
\hline
\end{tabular}

** Korelasyon 0.01 düzeyinde çok önemli; *Korelasyon 0.05 düzeyinde önemli 
Çizelge 5. C horizolarına ait toprak parametrelerine ilișkin korelasyon matrisi

Table 5. Correlation matris of soil parametres for $C$ horizons of soils

\begin{tabular}{|c|c|c|c|c|c|c|c|c|c|c|c|c|}
\hline & EC & Kireç & $\mathrm{OM}$ & KDK & $\mathrm{Na}$ & K & $\mathrm{Ca}+\mathrm{Mg}$ & Kil & Silt & Kum & Yükseklik & Eğim \\
\hline $\mathrm{pH}$ & -0.443 & 0.597 & -0.205 & 0.327 & 0.767 & 0.513 & 0.264 & 0.385 & 0.278 & -0.554 & -0.515 & -0.554 \\
\hline EC & & 0.053 & 0.433 & 0.440 & -0.672 & -0.688 & 0.534 & -0.045 & 0.582 & -0.338 & 0.570 & -0.297 \\
\hline Kireç & & & 0.515 & 0.622 & 0.096 & 0.060 & 0.626 & 0.141 & 0.539 & -0.491 & 0.337 & -0.517 \\
\hline OM & & & & 0.013 & -0.759 & -0.753 & 0.106 & -0.669 & 0.640 & 0.225 & $0.914^{*}$ & 0.236 \\
\hline KDK & & & & & 0.182 & 0.237 & $0.993^{* *}$ & 0.725 & 0.303 & $-0.899 *$ & 0.088 & $-0.923^{*}$ \\
\hline $\mathrm{Na}$ & & & & & & $0.895^{*}$ & 0.073 & 0.675 & -0.342 & -0.427 & $-0.886^{*}$ & -0.450 \\
\hline K & & & & & & & 0.120 & 0.750 & -0.638 & -0.306 & -0.725 & -0.366 \\
\hline $\mathrm{Ca}+\mathrm{Mg}$ & & & & & & & & 0.649 & 0.382 & -0.877 & 0.183 & $-0.895^{*}$ \\
\hline Kil & & & & & & & & & -0.285 & -0.778 & -0.544 & -0.815 \\
\hline Silt & & & & & & & & & & -0.380 & 0.408 & -0.319 \\
\hline Kum & & & & & & & & & & & 0.257 & $0.995^{\star *}$ \\
\hline Yükseklik & & & & & & & & & & & & 0.251 \\
\hline
\end{tabular}

miktarıyla OM, silt ve eğim arasındaki korelasyon orta, KDK, Ca+Mg ile ise yüksek olup, önemsiz düzeyde gerçekleșmiștir. OM, yükseklik ile önemli düzeyde çok yüksek pozitif korelasyon vermiștir. KDK miktarı, Ca+Mg ile çok önemli düzeyde pozitif korelasyon; kum ve eğimle ise önemli düzeyde çok yüksek negatif korelasyonlar göstermiștir. Na 'la K arasında önemli düzeyde çok yüksek pozitif, yükseklikle ise negatif korelasyonlar saptanmıștır. $\mathrm{Ca}+\mathrm{Mg}$ değerleriyle eğim arasında önemli düzeyde negatif yüksek korelasyon belirlenmiștir. Kil miktarı yükseklik ve eğimle sırasıyla orta ve yüksek șiddette negatif korelasyonlar göstermiștir. Silt ile diğer tüm toprak özellikleri arasındaki korelasyonlar önemsiz olup, zayıf, orta ve yüksek șiddette gerçekleșmiștir. Yükseklikle pozitif orta, eğim ile ise zayıf negatif korelasyon vermiștir. Topraktaki kum miktarı ile yükseklik arasında zayıf, eğim arasında ise çok önemli düzeyde çok yüksek korelasyon belirlenmiștir.

Korelasyon katsayısı parametreler arasında doğrusal ilișkiyi ifade ettiğinden, özellikler arasındaki bazı ilișkilerin düșük olmasının nedeni, doğrusal olmayan ilișkilerin mümkünlüğü, ilișkilerin doğrusallașma sürecinin kısa olmaması, bazı parametrelerin değișme aralıklarının dar olması, parametrelerin karșılıklı etkisinin farklılığı, yükseklik ve eğime bağlı olarak parametrelerin düzensiz değișimi, ana materyalin ilkin bileșenlerinin belirlenmesinin zorluğu, toprak profillerinin oluștuğu jeomorfolojik koșulların çok nadir durumlarda benzerlik göstermesi, yükseklik ve eğimin topraktaki makro süreçlerin hızına ve yönüne etkisi gibi durumlar olabilir.

\section{Farklı Toprak Horizonlarının Bazı Fiziksel ve Kimyasal Özellikleri Arasındaki Regresyon Modelleri}

Toprak özellikleri arasındaki regresyon modeller, özellikler arasındaki nicel ilișki durumunu ifade etmektedir. Bu modeller, deneysel değerleri genelleștirmekte; yerel, bölgesel ve global düzeyde olușturulmakta, toprak ve iklim koșullarına göre farklılık göstermektedir.

Regresyon modellerinin olușturulmasında toprak parametrelerine ilișkin korelasyon analizi sonuçları dikkate alınmıștır. Aralarındaki korelasyon ilișkileri çok düșük düzeyde olan parametreler modellerin olușturulmasında kullanılmamıștır. Kesit üzerinde yer alan toprakların A horizonlarının bazı özellikleri arasındaki regresyon modelleri așağıdaki biçimde belirlenmiștir (Çizelge 6)

Çizelge 6'dan da görüldüğü gibi, toprakların A horizonlarının bazı özellikleri arasındaki regresyon modellerinin regresyon katsayıları (regresyon denklemlerinin belirleme katsayısı) yüksek ve çok yüksek düzeyde olup, 0.615-0.998 arasında değișmektedir. 1. ve 4. modellere göre, organik madde, kil, Ca+Mg özellikleri KDK'nın artıșını etki yapmaktadır. Özelliklerin çarpımını (OM, Kil) ve kare kökünü $(\sqrt{\text { Kil }})$ ifade eden terimlerin modele dahil edilmesi, modellerin performansını 
Çizelge 6. Toprakların A horizonlarının bazı özellikleri arasındaki regresyon modelleri

Table 6. Regression models between some parameters for A horizons of soils

\begin{tabular}{|c|c|c|}
\hline & & $R^{2}$ \\
\hline 1. & $\mathrm{KDK}=12.2+2.15 \mathrm{OM}+0.485 \mathrm{Kil}+0.142 \mathrm{Eğim}$ & 0.902 \\
\hline 2. & KDK $=9.5+22.2 \mathrm{OM}+0.512$ Kil -0.627 Eğim $-0.310 \mathrm{OM} \cdot$ Kil & 0.961 \\
\hline 3. & $\mathrm{KDK}=1.16+1.01(\mathrm{Ca}+\mathrm{Mg})-0.0085 \mathrm{Kil}$ & 0.994 \\
\hline 4. & $\mathrm{KDK}=-17.8+0.938(\mathrm{Ca}+\mathrm{Mg})-0.518 \mathrm{Kil}+6.79 \sqrt{\mathrm{Kil}}$ & 0.996 \\
\hline 5. & $\mathrm{OM}=-3.02+0.0156 \mathrm{Kil}+0.092 \mathrm{KDK}+0.0532 \mathrm{Eğim}$ & 0.704 \\
\hline 6. & $\mathrm{OM}=22.9+0.777 \mathrm{Kil}+0.150 \mathrm{KDK}+0.0863 \mathrm{Eğim}-9.56 \sqrt{\text { Kil }}$ & 0.970 \\
\hline 7. & Kil $=78.4-1.08$ Kum + 0.173 Eğim & 0.996 \\
\hline 8. & Kil $=57.7-1.72 \mathrm{Kum}+0.157$ Eğim $+7.54 \sqrt{\text { Kum }}$ & 0.998 \\
\hline 9. & Kireç $=-1.27+0.0495(\mathrm{Ca}+\mathrm{Mg})-0.0049$ Kil & 0.615 \\
\hline 10. & Kirec $=23.6+1.06(\mathrm{Ca}+\mathrm{Mg})-0.395 \mathrm{Kil}-13.0 \sqrt{C a+M g}+5.2 \sqrt{\mathrm{Kil}}$ & 0.713 \\
\hline
\end{tabular}

** Korelasyon 0.01 düzeyinde çok önemli; *Korelasyon 0.05 düzeyinde önemli

artırmıștır. Aynı durum 5. ve 10. modeller için de söz konusu olmaktadır. 5. ve 6. modellerde, kil, KDK ve eğimin organik madde artıșına etkisi gözükmektedir. 7. ve 8. modellere göre, kil miktarının değișimine kum negatif, eğimin ise pozitif etkiyapmaktadır. Kireç miktarına, Ca+Mg'nin pozitif, kilin ise negatif etkisi 9. ve 10. modellerden gözükmektedir. Toprakların B horizonlarının bazı özellikleri arasındaki regresyon modellerinin $\left(R^{2}\right)$ orta șiddette, yüksek ve çok yüksek düzeyde olup, 0.418-0.998 arasında değișmektedir (Çizelge 7).

En düșük regresyon katsayısı $\left(R^{2}=0.418\right) 9$. regresyon modelinde saptanmıștır. Regresyon katsayısının düșük olması, eğim faktörünün kil ve kum miktarına düzensiz etkisinden kaynaklanmıș olabilir. Doğrusal olmayan terimler regresyon modellerinin korelasyon katsayılarının yükselmesine neden olmaktadır.

Toprakların C horizonlarına ait bazı özellikler arasındaki regresyon modelleri Çizelge 8'de verilmiștir. Modellerin regresyon katsayısı 0.5530.997 arasında değișmekte; en düșük regresyon katsayısı kireç ile Ca+Mg, kil ve eğim arasında, en yüksek ise KDK'nı ifade eden modellerde bulunmuștur. Regresyon modellerin, özelliklerin karekökünü ve karesini içeren polinomlarla ifadesi, yüksek regresyon katsayısı vermiștir. Bu ise, genel olarak tahminin önem düzeyini artırmaktadır.

Çizelge 7. Toprakların B horizonlarının bazı Özellikleri arasındaki regresyon modelleri

Table 7. Regression models between some parameters for $B$ horizons of soils 8

\begin{tabular}{|c|c|c|}
\hline 1. & $\mathrm{pH}=5.41-2.34 \mathrm{Na}+5.16 \sqrt{\mathrm{Na}}$ & 0.686 \\
\hline 2. & $\mathrm{pH}=6.86+1.29 \sqrt{\mathrm{Na}}$ & 0.614 \\
\hline 3. & KDK $=97.7-7.92 \mathrm{OM}-0.708$ Kil -0.680 Eğim & 0.930 \\
\hline 4. & KDK $=142-39.6 \mathrm{OM}-1.44$ Kil -0.643 Eğim +0.536 OM.Kil & 0.950 \\
\hline 5. & $\mathrm{KDK}=3.75+0.908(\mathrm{Ca}+\mathrm{Mg})+0.0258 \mathrm{Kil}$ & 0.987 \\
\hline 6. & $\mathrm{KDK}=168+0.945(\mathrm{Ca}+\mathrm{Mg})+2.99 \mathrm{Kil}-44.5 \sqrt{\mathrm{Kil}}$ & .998 \\
\hline 7. & $\mathrm{OM}=11.3-0.0830 \mathrm{Kil}-0.111 \mathrm{KDK}-0.0896$ Eğim & 0.933 \\
\hline 8. & $\mathrm{OM}=59.7+0.777$ Kil -0.107 KDK -0.0550 Eğim $-13.0 \sqrt{\text { Kil }}$ & 0.981 \\
\hline 9. & Kil $=39+5.1$ Kum - 15.3 Eğim - $0.126(\text { Kum })^{2}+1.59(\text { Eğim })^{2}$ & 0.418 \\
\hline 10. & Kireç $=0.929-0.00543(\mathrm{Ca}+\mathrm{Mg})+0.00361 \mathrm{Kil}+0.0417$ Eğim & 0.906 \\
\hline 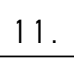 & Kireç $=18.9+0.384(C a+M g)-0.00050$ Kil +0.0561 Eğim $-5.27 \sqrt{C a+M g}$ & 0.981 \\
\hline
\end{tabular}


Çizelge 8. Toprakların C horizonlarının bazı Özellikleri arasındaki regresyon modelleri

Table 8. Regression models between some parameters for $C$ horizons of soils

\begin{tabular}{|c|c|c|}
\hline & & $R^{2}$ \\
\hline 1. & $\mathrm{pH}=5.38+2.55 \sqrt{\mathrm{Na}}$ & 0.623 \\
\hline 2. & $\mathrm{pH}=-7.45-14.9 \mathrm{Na}+30.7 \sqrt{\mathrm{Na}}$ & 0.811 \\
\hline 3. & $\mathrm{KDK}=4.9+18.5 \mathrm{OM}+0.433 \mathrm{Kil}-0.386$ Eğim & 0.992 \\
\hline 4. & $\mathrm{KDK}=0.97+0.924(\mathrm{Ca}+\mathrm{Mg})+0.0646 \mathrm{Kil}$ & 0.997 \\
\hline 5. & $\mathrm{KDK}=3.77+0.947(\mathrm{Ca}+\mathrm{Mg})+0.142 \mathrm{Kil}-1.09 \sqrt{\mathrm{Kil}}$ & 0.997 \\
\hline 6. & $\mathrm{KDK}=6.9+1.13(\mathrm{Ca}+\mathrm{Mg})+0.0700 \mathrm{Kil}-2.3 \sqrt{C a+M g}$ & 0.997 \\
\hline 7. & $\mathrm{OM}=-0.121-0.0234 \mathrm{Kil}+0.0508 \mathrm{KDK}+0.0172 \mathrm{Eğim}$ & 0.984 \\
\hline 8. & Kil $=26.4+3.38$ Kum - 10.8 Eğim & 0.779 \\
\hline 9. & Kil $=-52+8.2$ Kum -15.1 Eğim $-0.29(\text { Eğim })^{2}$ & 0.796 \\
\hline 10. & Kil $=-192+0.95$ Kum - 17.2 Eğim $+65 \sqrt{\text { Kum }}$ & 0.799 \\
\hline 11. & Kireç $=2.9+0.124(\mathrm{Ca}+\mathrm{Mg})-0.073 \mathrm{Kil}-0.158$ Eğim & 0.553 \\
\hline
\end{tabular}

Yapılan araștırmalar, regresyon modellerinin toprak özelliklerinin karesi, kare kökü ve çarpımını kapsayan polinomlarla ifadesinin, regresyon katsayısını, dolayısıyla tahminin önem düzeyini yükselttiğini göstermektedir (Kosheleva vd., 2002; Gülser vd., 2007).

Diğer modellerde olduğu gibi, regresyon modellerinde de, gerçek ortamdaki parametreler arasındaki ilișkilerin ve karșııklı etkilerin detaylı matematiksel ifadesi mümkün olmamaktadır. Parametreler arasındaki fonksiyonel ilișkilerin belirlenmesinde, bazı sınırlamaların dahil edilmesi, regresyon modellerinin olumsuz yanı olmaktadır. Polinom fonksiyonların kullanılması, bu olumsuzluğun aradan kaldırımasına imkan sağlamaktadır.

\section{SONUÇ}

Yapılan bu çalıșmada, Samsun-Bafra karayolunun güneyinde, Engiz Beldesine bağı Dağköy mevkii içerisinde farklı topografik pozisyonlarda (tepe üstü düzlük, yamaç ve taban araziler) yer alan bazaltik ana materyal üzerinde olușmuș toprakların; fiziksel, kimyasal özellikleri belirlenmiș ve sınıflamaları yapılmıș; genetik horizonların topografik ve toprak özellikleri arasında doğrusal regresyon modelleri olușturulmuștur. Çalıșmada deniz seviyesinden 20-251 m arasında Kuzey-Güney kesiti üzerinde fraklı topografik pozisyonlardan toplam altı adet profil incelenmiștir. Toprakların gerek arazi morfolojik incelemeleri gerekse de alınan toprak örneklerinde yapılan labaratuvar analizler sonucu kesit üzerinde eğimli ve yamaç arazilerde yer alan topraklar Lithic Ustorthent alt grubunda sınıflandırıırken, düz düze yakın eğimli taban ve tepe/plato düzlüklerinde yer alan topraklar ise Typic Haplustert, Vertic Haplustept ve Typic Haplustept olarak sınıflandırımıștır. Aynı ana materyal olmasına karșın, aynı alan içerisinde bu denli faklı toprakların olușmasında diğer bir ifade ile geç ve olgun toprakların lokal bir alan içerisinde birlikte yer almalarının sebebi, topografya veya yerel rölyefin ana materyal ve zamanın toprak olușum süreç ve ișlemleri üzerinde önemli etkisi olduğudur. Ayrıca, bu duruma topraklarınüzerinde yer alan vejetasyonun sıklığı, çeșidi gibi faktörler de önemli etki yaptığı görülmüștür. Toprakların olgunlașmasında veya genç kalmalarında özellikle yamaç arazilerde yer alan topraklar da su hareketi dolaysıyla toprak tașınımı ve birikimi yerinde olușum kadar etkili olduğu görülmektedir.

Araștırma topraklarının B horizonuna ait 9. ve $C$ horizonuna ait 11. modellerde regresyon katsayıları orta; diğer tüm modellerde ise yüksek ve çok yüksek düzeyde olmaktadır. Dolayısıyla, elde edilen regresyon denklemleri, benzer özelliklere sahip olan toprakların $\mathrm{pH}, \mathrm{KDK}, \mathrm{OM}$, kil, kireç değerlerinin tahmininde kullanılabilir.

Genel olarak, toprak araștırmalarında elde edilen deneysel eğrilerin pratik olarak polinom fonksiyonlarla ifadesi mümkün olabilmektedir (Schaap, 2004). Araștırmanın amacına uygun olarak regresyon modelleri farklılık gösterdiğinden, farklı modellerin karșılaștırılması ve en iyisinin bulunması için genel bir kural olmamaktadır. 
Regresyon modellerinden hesaplanan teorik değerlerle, yerel, bölgesel veya global düzeyde olușturulmuș toprak verileri arasında karșılaștırılma yapılır ve modellerin yeterlilik düzeyi belirlenir. Bouma (1989)'a göre, regresyon modeller (pedotransfer fonksiyonlar) elde edilen verileri, gerekli verilere dönüștürmektedir. Regresyon modellerin uygulamasının kolaylığını göz önüne alarak, yerel ve bölgesel düzeyde bu modellerin yapılması için, uygun toprak verileri bankasının olușturulması güncel problemlerden biridir (Wösten vd., 1990; Shein ve Arkhangel'skaya, 2006).

\section{TESEKKÜR}

Bu çalıșmada kullanılan veriler 2130073 kodlu proje kapsamında yapılan çalıșmanın bir kısmını olușturmakta olup, tüm çalıșma TUBiTAK-TOVAG tarafından desteklenmiștir. Desteklerinden dolayı teșekkür ederiz.

\section{KAYNAKLAR}

Bayraklı F, Ekberli I, Gülser C (1999). Azerbaycan Mil ovası topraklarının verimlilik düzeylerinin deneysel ve matematiksel olarak değerlendirilmesi. Ondokuz Mayıs Üniversitesi Ziraat Fakültesi Dergisi, 14(2): 138-153.

Bosch A, Dörfer C, He JS, Schmidt K., Scholten T (2016). Predicting soil respiration for the Qinghai-Tibet Plateau: An empirical comparison of regression models. Pedobiologia, 59: $41-49$

Bouma J (1989). Using soil surve data for quantitative land evaluation. Advances Soil Science, 9: pp. 177-213.

Bouyoucous GJ (1951). A Recalibration of Hydrometer for Making Mechanical Analysis of Soils, Agronomy Journal, 43(9): 434-443.

Candemir F, Gülser C (2012). Influencing factors and prediction of hydraulic conductivity in fine-textured alkaline soils. Arid Land Research and Management. 26: 15-31.

Carlona C, Valleb MD, Marcominia A (2004). Regression models to predict water-soil heavy metals partition coefficients in risk assessment studies. Environmental Pollution, 127: 109-115.

Ekberli İ, Dengiz O, Özdemir N, Göl C (2009). Topraktaki tuz miktarı ile toprağın bazı fiziksel-kimyasal özellikleri arasındaki ilișilerin incelenmesi. International Research Conference "Priority line of activity in the industry and working over of an agricultural output" dedicated to 80-years old of the academician K.U.Medeubekov Kazakh National Agricultural University (Almatı. 22.05. 2009), s. 677-683.

Ekberli i, Kerimova E (2005). Azerbaycan'ın Șirvan bölgesinde sulanan killi bir toprağın bazı fiziksel-kimyasal parametrelerinin değișimi. Ondokuz Mayıs Üniversitesi Ziraat Fakültesi Dergisi, 20(3): 54-59.

Ekberli I, Kerimova E (2008). Functional relationships between fertility and some soil parameters. Asian Journal of Chemistry, 20(3): 2320-2326.
Gülser C (2004). Tarla kapasitesi ve devamlı solma noktasının toprakların fiziksel ve kimyasal özellikleri ile ilișkili pedotransfer eșitliklerle belirlenmesi. Ondokuz Mayıs Üniversitesi Ziraat Fakültesi Dergisi, 19(3): 19-23.

Gülser C, Așkın T, Özdemir N (2003). Ondokuz Mayıs Üniversitesi Kampus topraklarının erozyona duyarlııklarının değerlendirilmesi. Ondokuz Mayıs Üniversitesi Ziraat Fakültesi Dergisi, 18(1): 1-6.

Gülser C, Candemir F, İç S, Demir Z (2007). Pedotransfer modellerle ince bünyeli topraklarda doygun hidrolik iletkenliğin tahmini. V. Ulusal Hidroloji Kongresi. Orta Doğu Teknik Üniversitesi. Ankara. 5-7 Eylül 2007, s. 563-569.

Jackson ML (1958). Soil Chemical Analysis. Englewood Cliffs, New Jersey: Prentice Hall Inc.

Korolev VA (2008). Changes in the main physical properties of ordinary chernozems under the impact of irrigation. Pocvovedeniye, 10: 1234-1240.

Kosheleva NE, Kasimov NS, Samonova OA (2002). Regression models fort he behavior of heavy metals in soils of the Smolensk-Moskow upland. Pocvovedeniye, 8: 954-966.

Li F, Shan X, Zhang T, Zhang S (1998). Evaluation of plant availability of rare earth elements in soils by chemical fractionation and multiple regression analysis. Environmental Pollution, 102: 269-277.

Liu J, Chao-Fu W, Oian X, Wei-Hua Z (2014). Capacities of soil water reservoirs and their better regression models by combining "merged groups PCA" in Chongqing. China. Acta Ecologica Sinica, 34: 53-65.

Purtova LN, Zimina MP (2007). Variability of physicochemical characteristics of brown forest soils within the phytogenic fields of trees (the Southern Far east). Pocvovedeniye, 1: 31-37.

Qian J, Wang Z, Shan X, Tu O, Wen B, Chen B (1996). Evaluatıon of plant avallabılıty of soll trace metals by chemıcal fractıonatıon and multıple regressıon analysıs. Environmental Pollution, 91 (3): 309-315.

Rhoades JD (1986). Cation Exchange Capacity, Chemical and Microbiological Properties. Methods of Soil Analysis, Part II. Madison: ASA and SSSA Agronomy Monograph, No: 9.

Schaap MG (2004). Accuracy and unsertainty in PTF predictions. Development of pedotransfer functions in soil hydrology. Elsevier, p.33-43.

Shein EV, Arkhangel'skaya TA (2006). Pedotransfer functions: state of the art, problems, and outlooks. Pocvovedeniye, 10: 1205-1217.

Silva Chagas C, Carvalho Junior W, Barge Bhering S, Calderano Filho B (2016). Spatial prediction of soil surface texture in a semiarid region using random forest and multiple linear regressions. Catena, 139: 232-240.

Simon M, Garcia I (1999). Physico-chemical properties of the soil-saturation extracts: estimation from electrical conductivity. Geoderma, 90: 99-109.

Soil Survey Staff (1992). Procedures for Collecting Soil Samples and Methods of Analysis for Soil Survey. Soil Surv. Invest. Report, Washington D.C., USA: I. U.S. Gov. Print. 
Office.

Soil Survey Staff (1993). Soil Survey Manual, USDA Handbook, Washington D.C., No: 18.

Soil Survey Staff (1999). Soil Taxonomy. A Basic of Soil Classification for Making and Interpreting Soil Survey. USDA Handbook, Washington D.C., No: 436.

Soil Survey Staff (2004). Soil Survey Laboratory Methods Manual Soil Survey Investigations Report, USDA, No:42.

Thorntwaite CW (1948). An Approach to a Rational Classification of Climate. Geographic Review, 38: 55-94.

Utkaeva VF (2007). Specific surface area and wetting heat of different soil types in European Russia. Pocvovedeniye, 11 : 1336-1346.

Verachtert E, Van Den Eeckhaut M, Poesen J, Govers G, Deckers J (2011). Prediction of spatial patterns of collapsed pipes in loess-derived soils in a temperate humid climate using logistic regression. Geomorphology, 130: 185-196.

Wösten JHM, Schuren CHJE, Bouma J, Stein A (1990). Functional sensitivity analysis of four methods to generate soil hydraulic functions. Soil Sci. Soc. Am. J., 54: 832-836.

Yukselen-Aksoy Y, Kaya A (2010). Method dependency of relationships between specific surface area and soil physicochemical properties. Applied Clay Science, 50: 182190.

Zaydelman FR (1987). Meliorasiya pocv. İzdatelstvo Moskovskogo Universiteta, 304 s.

Zhumabekov EZh (2005). Physical and mechanical properties of soil in Kyrgyzia. Pocvovedeniye, 7: 851-858. 


\title{
Ankara İli Kırsal Alanda Süt Tüketim Düzeylerinin Belirlenmesi
}

\author{
Yasemin DEMIR ${ }^{*}$ \\ Erdoğan GÜNEȘ² \\ 'Toprak Gübre ve Su Kaynakları Merkez Araștırma Enstitüsü Müdürlüğü, Ankara \\ ${ }^{2}$ Ankara Üniversitesi Ziraat Fakültesi Tarım Ekonomisi Bölümü, Ankara
}

\begin{abstract}
* Sorumlu yazar e-posta (Corresponding author e-mail): yasemindemir@tarim.gov.tr Geliș tarihi (Received) : 15.01.2017

Kabul tarihi (Accepted): 03.03.2017

Öz

Bu çalıșmada kırsal alanda tarımsal üretim faaliyetinde bulunan hane halklarının süt tüketim düzeyleri ve tercihleri incelenmiștir. Bu doğrultuda Ankara iline bağı Polatlı, Beypazarı, Ayaș ilçelerinde 122 birey ile 2016 yılının Nisan-Mayıs aylarında yüz yüze görüșmeler yoluyla anketler yapılmıștır. Anket sonuçlarını yorumlamak için basit aritmetik ortalama, oranlama, yüzde hesapları ve $\chi 2$ analizi kullanılmıștır. Görüșülen ailelerin hanehalkı genișliği ortalama 3.6 kiși ve ortalama süt tüketimi kiși bașına yıllık 28.4 It olarak belirlenmiștir. İșletmelerin \%59'unda süt üretimi yapılırken, yapılan $\chi 2$ analizi sonucunda ailelerin süt tüketim düzeylerinin ișletmelerin süt üretiminde bulunma durumuna ve ișletme sahiplerinin yaș gruplarına bağlı olarak değiștiği belirlenmiștir.
\end{abstract}

Anahtar Kelimeler: Süt, tüketim, Ankara, kırsal Alan

\section{The determination of milk Consumption Level in Ankara Province}

\begin{abstract}
In this study, milk consumption levels and preferences of producers operating in agricultural sector in rural areas were analyzed. In this direction, polls of Ankara, Polatli, Beypazarı, Ayaș provinces were interviewed by face-to-face interviews with 122 producers in April-May 2016. In order to interpret the survey results, simple arithmetic mean, ratio, percentage calculations, graph and $\chi 2$ analysis were used. In the interviews, the average household size of the producers is composed of 3.6 persons and the average milk consumption per capita is 28.4 It per capita. While milk production was conducted in $59 \%$ of the household establishments, it was determined that milk consumption levels of the families as a result of the $\chi 2$ analysis changed according to the presence of milk production and the age groups of the business owners.
\end{abstract}

Key words:Milk, consumption, Ankara, rural area 


\section{Giriș}

Süt ve süt ürünleri özellikleri bakımından insan sağlığı için her gün tüketilmesi gereken gıda maddeleri arasında yer almaktadır. Sütün en verimli ve yaygın olduğu șekli içme sütü olarak kullanılmasıdır. Bunun en önemli nedeni, sütün çeșitli biçimlerde mamul maddelerle ișlenmesi ve dayanıklı hale sokulması sırasında bileșimindeki bazı besin elementlerinde kayıpların ortaya çıkmasıdır (Çetinkaya, 2010). Yapılan araștırmalarda 1 bardak sütle 6 yașındaki bir çocuğun günlük intiyac olan B12 vitamininin \%98'inin, fosforun $\% 55$ 'inin, kalsiyumun \%52'sinin, B12 vitamininin \%44'ünün karșılandığı, özellikle çocukların güçlü kemik yapısına sahip olması için süt tüketiminin çok önemli olduğu belirtilmektedir (Anonim, 2016a). Bununla birlikte hayatın belirli dönemlerinde süt tüketiminin önemi büyüktür. Ergenlik, yetișkinlik ve yașlllık dönemlerinde, menopoz döneminde, hamilelik ve emzirme sürecinde önerilen süt tüketim miktarı süt ürünlerinin tüketimi haricinde günlük 2 su bardağıdır (Anonim, 2016b). Kısaca cinsiyet ve yaș grubu ayrımı yapmaksızın her insanın günlük beslenmesine süt ürünlerinin yanı sıra sütü özellikle dahil etmesi gerekmektedir.

Süt tüketimi ülkeler için bir gelișmișlik göstergesi olarak görülmektedir. Birçok Avrupa ülkesinde ve Avustralya'da kiși bașına yıllık süt tüketimi 100 kg'ı așmakta, ABD ve Kanada'da 100 kg'a yaklașmaktadır (Anonim 2016c). Ancak Türkiye'de kayıt altına alınan süt üretim miktarları ve dıș ticaret verileri dikkate alındığında kiși bașına içme sütü tüketiminin 37 kg'a yakın olduğu tahmin edilmektedir (Onurlubaș ve Çakırlar, 2016). Bu nedenle gerek sağlık uzmanları, gerekse konuyla ilgili yapılan araștırmalar süt tüketiminin önemine ișaret etmekte ve tüketimin artırılması için uyarılarda bulunmaktadır.

Süt tüketim düzeyi genel olarak düșük olmasıyla birlikte sosyo-ekonomik faktörler de bu düzeyi etkilemektedir. Yapılan çalıșmalarda da süt tüketim miktarları ve harcamalarda süte ayrılan paylar farklııı göstermektedir. Grigg (1999), Akdeniz ülkelerinde yaptığı çalıșmasında gıda tüketim modellerini incelemiș ve bölgesel farklılıklar gösterdiğini belirtmiștir. Bunun yanı sıra Akbay ve Tiryaki (2007)'nin çalıșmalarında, eğitim düzeyi ve gelir ile süt tüketimi arasında pozitif bir ilișki olduğunu süt tüketim alıșkanlıkları ile gelir, eğitim, yaș, cinsiyet ve annenin statüsü arasında yakın ilișki olduğunu belirtmișlerdir. Hanta (1994) Adana ili kentsel alanda 200 ailenin hayvansal gıda tüketim yapısını incelemiș ve toplam hayvansal gıda tüketim harcamaları içinde süt ve süt ürünleri harcamalarının oranını \%33.2 olarak hesaplamıștır. Șimșek ve ark. (2005) İstanbul ilinde ailelerin içme sütü ile ilgili alıșkanlıklarını belirlemek için yaptıkları araștırmalarında, yıllık kiși bașına süt tüketim miktarını 34 It olarak hesaplamıșlardır. Armağan ve Akbay (2008) ise Aydın ili kentsel alanında bazı hayvansal ürünler tüketiminin ekonometrik analizini yapmıșlar ve yılda kiși bașına $48.2 \mathrm{~kg}$ içme sütü tüketildiğini hesaplamıșlardır. Çetinkaya (2010) Kafkas Üniversitesi'ndeki öğrencilerin süt ve süt ürünleri tüketimini incelemiș, öğrencilerin $\% 33$ 'ünün süt tükettiği, \%67'sinin ise hiç süt tüketmediğini ve büyük çoğunluğunun düzenli süt tüketimi alıșkanlığının olmadığını tespit etmiștir.

Bu araștırmada kentsel alanda yapılan çalıșmaların yanında kırsal alanda konuyla ilgili yapılan çalıșmaların azlığı nedeniyle tarımsal faaliyette bulunan ailelerde süt tüketim düzeyleri ve çeșitli parametreler arasında ilișkiler incelenmiștir.

\section{MATERYAL VE YÖNTEM}

\section{Materyal}

Araștırmanın ana materyalini, Ankara iline bağlı ilçelerde tarım sektöründe faaliyet gösteren ve kırsal alanda yașayan üreticilerle yüz yüze anket yöntemiyle elde edilen veriler olușturmuștur.

İkincil veriler ise konu ile ilgili daha önce yapılmıș çalıșmalar ile Türkiye İstatistik Kurumu istatistiki kayıtlarından ve çeșitli sivil toplum örgütlerinin yayınlandığı verilerden meydana gelmiștir.

\section{Yöntem}

\section{Örnekleme Sırasında Uygulanan Yöntem}

Araștırmada Ankara ilinde kırsalda tarımsal üretimde bulunan ișletmelerin tamamı ile görüșmek, ekonomik ve teknik açıdan mümkün olamayacağı için örnekleme yapılması uygun görülmüștür. Popülasyonu olușturan 2014 yılı Çiftçi Kayıt Sistemi verilerine göre ișletmelerin kayıtlı ișletme arazisi genișlikleri dikkate alınarak tabakalı örnekleme yöntemine göre \% 90 güven sınırları ile anket uygulanacak örnek ișletme sayıları bulunmuștur (Yamane, 2001). 
$\mathrm{n}=\frac{\left[N \sum N_{h} S_{h}^{2}\right]}{N^{2} D^{2}+\sum N_{h} S_{h}^{2}}$

$\mathrm{n}$ = örnek ișletme sayısı

$N_{\mathrm{h}}=$ h'ıncı tabakadaki ișletme sayısı

Sh = h'ıncı tabakanın standart sapması

$N=$ Toplam ișletme sayısı

$D^{2}=(d / t)^{2}$ değeri olup.

$d$ = Popülasyon ortalamasından izin verilen hata miktarını (Ortalama arazi genișliğinin \%10'u).

$\mathrm{t}=$ Araștırmada öngörülen \%90 güven sınırına karșilık gelen t tablo değerini ifade etmektedir.

Araștırmada anketlerininyapılacağıilçelersosyoekonomik farklılıklar göz önünde bulundurularak gayeli örnekleme yöntemi ile seçilmiștir. Seçilen ilçeler Ankara ili için üretimin yoğun yapıldığı, ürün çeșitliliğinin fazla olduğu ilçelerdir. Bu doğrultuda üretici anket uygulamalarının Polatlı, Beypazarı ve Ayaș ilçelerinde yapılmasına karar verilmiștir. Uygulanacak toplam anket sayısı 122 olarak hesaplanmıș ve anketlerin 82'si Polatlı, 20'si Ayaș, 20'si Beypazarı ilçelerinde 2016 yılı Nisan ve Mayıs ayları arasında yapıımıștır.

Çizelge 1. Anket Yapılan Gruplar ve Anket Sayıları

Table 1. Survey Groups and Survey Numbers

\begin{tabular}{ccc} 
Da & Varyasyon Katsayısı & Anket Sayısı \\
\hline$<41$ & 39.41 & 34 \\
$41-150$ & 36.00 & 30 \\
$151-400$ & 28.02 & 40 \\
$400+$ & 38.43 & 18
\end{tabular}

Toplam: 122
Anket yapılan ilçelere ait köyler, bölgedeki dağıım ve tarımsal potansiyel dikkate alınarak amaçlı olarak belirlenmiș, tesadüfi olarak seçilen ișletmelerde uygulanmıștır. Polatlı ilçesinde Basri, Yeni Köseler, Ömerler, Beyliköprü, Cekirdeksiz, Karacaahmet, Gedikli, Karahamzalı, Yassıhüyük, Tatlıkuyu köylerinde, Beypazarı ilçesinde Dikmen, Dibecik, Fasıl, Oymaağaç, Yoğunpelit, Tacettin, Acısu, Tahirler, Harmancık köylerinde ve Ayaș ilçesinde Oltan, Ilıca, Akkaya, Sinanlı, İlhan, Evci köylerinde anketler tamamlanmıștır.

Araștırmada üreticilerin demografik özellikleri, ekonomik yapıları, eğitim durumları, süt tüketim tercihleri gibi özellikler basit aritmetik ortalama, oransal hesaplama, indeks hesaplama yöntemleriyle gösterilmiștir. Çalıșmanın konusu olan süt tüketim tercihleri hakkında belirlenen faktörler ve sosyo-ekonomik göstergeler arasındaki ilișkiler, Ki-kare ( $\chi 2$ ) (Düzgüneș ve ark. 1993, Sokal ve Rohlf 1995) analiziyle açıklanmıștır.

Ki-kare analizi, gözlenen frekanslar ile beklenen frekanslar arasındaki farkın istatistik olarak anlamlı olup olmadığı temeline dayanır. Ki-kare dağıımı, genellikle iki bağımsız niteliksel kriteri test etmek için kullanııır. Sıfır hipotezi, iki kriterin bağımsız olduğunu; araștırma hipotezi ise, iki kriterin arasında ilișki olduğunu ifade eder (Güngör ve Bulut, 2008).

\section{BULGULAR VE TARTISMA}

Üreticilerin yașları üç gruba ayrılarak ișletme büyüklüklerine göre Çizelge 2'de verilmiștir. Bu gruplamaya göre 30 ve daha küçük yaș grubunda olan üreticiler anket yapılan ișletmelerin yalnızca \%4.1'ni olușturmaktadır. Çoğunluk ise 50 yaș ve üzerindeki ișletme sahiplerinden olușmaktadır.

Çizelge 2. İșletme Büyüklük Gruplarına Göre Üreticilerin Yaș Grupları

Table 2. Age Groups of Farmers by Farm Size Groups

\begin{tabular}{|c|c|c|c|c|c|c|}
\hline \multirow[t]{2}{*}{ Yaș } & \multicolumn{5}{|c|}{ Gruplar } & \multirow[b]{2}{*}{ Toplam } \\
\hline & & $<41$ & $41-150$ & $151-400$ & $>400$ & \\
\hline \multirow[t]{2}{*}{$\leq 30$} & Sayı & 4 & - & 1 & - & 5 \\
\hline & Oran & 11.8 & & 2.5 & & 4.1 \\
\hline \multirow[t]{2}{*}{$31-49$} & Sayı & 19 & 11 & 18 & 3 & 51 \\
\hline & Oran & 55.9 & 36,7 & 45.0 & 16.7 & 41.8 \\
\hline \multirow[t]{2}{*}{$\geq 50$} & Sayı & 11 & 19 & 21 & 15 & 66 \\
\hline & Oran & 32.3 & 63.3 & 52.5 & 83.3 & 54.1 \\
\hline \multirow[t]{2}{*}{ Toplam } & Sayı & 34 & 30 & 40 & 18 & 122 \\
\hline & Oran & 100 & 100 & 100 & 100 & 100 \\
\hline
\end{tabular}


İncelenen ișletmelerde üreticilerin eğitim durumları arazi büyüklük gruplarına göre Çizelge 3'de verilmiștir. Küçük yașta aile ișletmesinde çalıșmaya bașlayan üreticilerin eğitimi büyük çoğunlukla ilkokul düzeyinde kalmaktadır. Görüșülen üreticilerin \%85,2'si ilkokul mezunudur.

İșletmelerin süt üretim faaliyet yapısı incelendiğinde, bunların \%59'unun süt sığırına sahip olduğu ve ișletmelerin süt üretimi yaptığı belirlenmiștir (Çizelge 4). Görüșülen ișletmelerin hiçbirinde koyun veya keçi sütü üretilmediği belirlenmiștir.

İșletmelerin ortalama gelirleri, aylık ortalama gıda harcamaları ve süt harcamaları Çizelge 5 'de verilmiștir. Buna göre araștırma alanında ișletme büyüklüğü arttıkça doğru orantılı olarak gelir ve gıda harcamalarında da artıș olduğu görülmüștür. Ortalama süt harcamalarının düșüklüğü, üreticilerin kendi ürettiği sütü tüketmelerinden kaynaklanmaktadır.

Çalıșmada ișletmelerde hane halkı genișliği ortalama 3.7 kiși olarak hesaplanmıștır. Ortalama aylık süt tüketimi aile bașına 11.7 It ve kiși bașına yıllık süt tüketim ise 28.4 It olarak hesaplanmıștır (Çizelge 6). Bu miktar hem Türkiye ortalamasından hem de önerilen miktarlardan düșüktür. Çelik ve ark. (2005), Șanlıurfa kentsel alanda yaptıkları çalıșmalarında aileler genelinde ortalama aylık süt tüketimi miktarını 16.2 litre olarak belirlemișlerdir.

Süt tüketim miktarları ișletmelerin süt üretimi yapma durumlarına göre incelendiğinde, üretimin olduğu ișletmelerde süt tüketiminin de arttığı görülmüștür (Çizelge 7). Süt üretimi yapan ișletmelerin \%50'si aylık aile bașına 1 1-20 It arasında süt tüketirken, üretim yapmayan ișletmelerde aile bașına aylık tüketim \%58 oranında 5 It'nin altında

Çizelge 3. İșletme Büyüklük Gruplarına Göre İșletme Yöneticilerinin Eğitim Durumu

Table 3. Educational Situations of Farmers by Farm Size Groups

\begin{tabular}{|c|c|c|c|c|c|c|}
\hline \multirow[t]{2}{*}{ Eğitim Durumu } & \multicolumn{5}{|c|}{ Gruplar } & \\
\hline & & $<41$ & $41-150$ & $151-400$ & $>400$ & \\
\hline \multirow[t]{2}{*}{ Okur-Yazar Değil } & Sayı & - & - & 1 & - & 1 \\
\hline & Oran & & & 2,50 & & 0.8 \\
\hline \multirow[t]{2}{*}{ İlkokul } & Sayı & 25 & 26 & 36 & 17 & 104 \\
\hline & Oran & 73.5 & 86.7 & 90.0 & 94.4 & 85.2 \\
\hline \multirow[t]{2}{*}{ Lise } & Sayı & 8 & 4 & 3 & 1 & 16 \\
\hline & Oran & 8.8 & 13.3 & 10.0 & 5.6 & 9.8 \\
\hline \multirow[t]{2}{*}{ Yük.Okul-Üniversite } & Sayı & 1 & - & - & - & 1 \\
\hline & Oran & 2,9 & - & - & - & 0,8 \\
\hline \multirow[t]{2}{*}{ Toplam } & Sayı & 34 & 30 & 40 & 18 & 122 \\
\hline & Oran & 100 & 100 & 100 & 100 & 100 \\
\hline
\end{tabular}

Çizelge 4. İșletme Büyüklük Gruplarına Göre Süt Üretimi Yapma Durumu

Table 4. Milk Production Status by Farm Size Groups

\begin{tabular}{|c|c|c|c|c|c|c|}
\hline \multirow[t]{2}{*}{ Süt Üretimi Yapma Durumu } & \multicolumn{5}{|c|}{ Gruplar } & \multirow[b]{2}{*}{ Genel (122) } \\
\hline & & $<41$ & $41-150$ & $151-400$ & $>400$ & \\
\hline \multirow[t]{2}{*}{ Evet } & Sayı & 19 & 18 & 23 & 12 & 72 \\
\hline & $\%$ & 55.9 & 60.0 & 57.5 & 66.7 & 59.0 \\
\hline \multirow[t]{2}{*}{ Hayır } & Sayı & 15 & 12 & 17 & 6 & 50 \\
\hline & $\%$ & 42.9 & 40.0 & 42.5 & 33.3 & 41.0 \\
\hline \multirow[t]{2}{*}{ Toplam } & Sayı & 34 & 30 & 40 & 18 & 122 \\
\hline & $\%$ & 100.0 & 100.0 & 100.0 & 100.0 & 100.0 \\
\hline$\chi^{2}=0.624$ & & $P=0.891$ & & & & \\
\hline
\end{tabular}


Çizelge 5. İșletme Büyüklük Gruplarına Göre Gelir Durumları, Gıda ve Süt Harcamaları

Table 5. Income Situations, Food and Milk Expendituresby Farm Size Groups

\begin{tabular}{llllll}
\multirow{2}{*}{ Değișken } & \multicolumn{4}{c}{ Gruplar } & \\
\cline { 2 - 5 } & $<41$ & $41-150$ & $151-400$ & $>400$ & Genel (122) \\
\hline Ortalama Gelir (TL/Ay) & 902.9 & 1178.3 & 1254.5 & 1486.1 & 1172.0 \\
\hline Gıda Harcamaları (TL/ay) & 251.1 & 298.1 & 331.8 & 346.9 & 303.3 \\
\hline Süt Harcamaları (TL/ay) & 13.5 & 10.3 & 10.5 & 5.0 & 10.5 \\
\hline
\end{tabular}

Çizelge 6. İșletme Büyüklük Gruplarına Göre Hanehalkı Genișliği ve Süt Tüketim Miktarları

Table 6. Household Width and Milk Consumption Quantitiesby Farm Size Groups

\begin{tabular}{llllll}
\hline \multirow{2}{*}{ Değișken } & \multicolumn{5}{c}{ Gruplar } \\
\cline { 2 - 5 } & $<41$ & $41-150$ & $151-400$ & $>400$ & Genel (122) \\
\hline Hanehalkı Genișliği(Kiși) & 3.4 & 3.5 & 3.9 & 4.1 & 3.7 \\
\hline Süt Tüketimi(It/ay) & 9.9 & 9.3 & 7.4 & 6.3 & 8.4 \\
\hline Kiși Bașına Süt Tüketimi (It/Yıl) & 36.1 & 32.1 & 23.7 & 18.2 & 28.4 \\
\hline
\end{tabular}

Çizelge 7. İșletmelerin Süt Üretimi Yapma Durumuna Göre Süt Tüketim Düzeyleri

Table 7. Milk Consumption Levels by Milk Production Status

\begin{tabular}{|c|c|c|c|c|c|c|}
\hline \multirow[t]{2}{*}{ Süt Üretimi Yapma Durumu } & \multicolumn{5}{|c|}{ Gruplar } & \multirow[b]{2}{*}{ Genel (122) } \\
\hline & & $1-5$ & $6-10$ & $11-20$ & $>20$ & \\
\hline \multirow[t]{2}{*}{ Evet } & Sayı & 12 & 19 & 36 & 5 & 72 \\
\hline & $\%$ & 16,7 & 26,4 & 50.0 & 6.9 & 100.0 \\
\hline \multirow[t]{2}{*}{ Hayır } & Sayı & 29 & 11 & 9 & 1 & 50 \\
\hline & $\%$ & 58.0 & 22.0 & 18.0 & 2.0 & 100.0 \\
\hline \multirow[t]{2}{*}{ Toplam } & Sayı & 41 & 30 & 45 & 6 & 122 \\
\hline & $\%$ & 33.6 & 24.6 & 36.9 & 4.9 & 100.0 \\
\hline$\chi^{2}=24.891$ & & $P=0.000$ & & & & \\
\hline
\end{tabular}

Çizelge 8. Yaș Gruplarına Göre Süt Tüketim Düzeyleri

Table 8. Milk Consumption Levels by Age Groups

\begin{tabular}{lllllll}
\hline \multirow{2}{*}{ Yaș Grupları } & \multicolumn{7}{c}{ Süt Tüketimi (It/ay) } & Genel (122) \\
\cline { 2 - 6 } & \multicolumn{7}{c}{$1-5$} & $6-10$ & $11-20$ & $>20$ & 5 \\
\hline \multirow{2}{*}{30} & Sayı & 2 & - & 2 & 1 & 4.1 \\
\hline \multirow{2}{*}{$31-49$} & Sayı & 8 & 13 & 26 & 4 & 51 \\
& $\%$ & 19.5 & 43.3 & 57.8 & 66.7 & 41.8 \\
\hline \multirow{2}{*}{$\geq 50$} & Sayı & 31 & 17 & 17 & 1 & 66 \\
& $\%$ & 75.6 & 56.7 & 37.8 & 16.7 & 54.1 \\
\hline \multirow{2}{*}{ Toplam } & Sayı & 41 & 30 & 45 & 6 & 122 \\
& $\%$ & 100.0 & 100.0 & 100.0 & 100.0 & 100.0 \\
\hline$\chi^{2}=19.454$ & DF $=6$ & $P=0.003$ & & & & \\
\hline
\end{tabular}


Çizelge 9. İșletme Büyüklük Gruplarına Göre Süt Temin Yerleri

Table 9. Milk Supply Locationsby Farm Size Groups

\begin{tabular}{|c|c|c|c|c|c|c|}
\hline \multirow[t]{2}{*}{ Süt Temin Yöntemi } & \multicolumn{5}{|c|}{ Gruplar } & \multirow[b]{2}{*}{ Genel (122) } \\
\hline & & $<41$ & $41-150$ & $151-400$ & $>400$ & \\
\hline \multirow[t]{2}{*}{ İșletmede Üretilen } & Sayı & 19 & 18 & 23 & 12 & 72 \\
\hline & $\%$ & 55.9 & 60.0 & 57.5 & 66.7 & 59.0 \\
\hline \multirow[t]{2}{*}{ Komșulardan Açık Süt } & Sayı & 11 & 10 & 14 & 6 & 41 \\
\hline & $\%$ & 32.4 & 33.3 & 35.0 & 33.3 & 33.6 \\
\hline \multirow[t]{2}{*}{ Ambalajlı Süt } & Sayı & 4 & 2 & 3 & - & 9 \\
\hline & $\%$ & 11.7 & 6.7 & 7.5 & & 7.4 \\
\hline \multirow[t]{2}{*}{ Toplam } & Sayı & 34 & 30 & 40 & 18 & 122 \\
\hline & $\%$ & 100 & 100 & 100 & 100 & 100 \\
\hline$\chi^{2}=2.532$ & & $=0.86$ & & & & \\
\hline
\end{tabular}

Çizelge 10. Süt Temininde Etkili Faktörler

Table 10. Effective Factors for Milk Supply

\begin{tabular}{|c|c|c|c|c|c|c|}
\hline \multirow[t]{2}{*}{ Değișken } & \multicolumn{5}{|c|}{ Gruplar } & \multirow[b]{2}{*}{ Genel (122) } \\
\hline & & $<41$ & $41-150$ & $151-400$ & $>400$ & \\
\hline \multirow[t]{2}{*}{ Güvenilir Oıması } & Sayı & 4 & 2 & 4 & 1 & 11 \\
\hline & $\%$ & 26.7 & 16.6 & 23.5 & 16.7 & 22.0 \\
\hline \multirow[t]{2}{*}{ Hijyenik Olması } & Sayı & 8 & 5 & 9 & 4 & 26 \\
\hline & $\%$ & 53.3 & 41.7 & 53.0 & 66.6 & 52.0 \\
\hline \multirow[t]{2}{*}{ Akrabalık-Komșuluk } & Sayı & 3 & 5 & 4 & 1 & 13 \\
\hline & $\%$ & 20.0 & 41.7 & 23.5 & 16.7 & 26.0 \\
\hline \multirow[t]{2}{*}{ Toplam } & Sayı & 15 & 12 & 17 & 6 & 50 \\
\hline & $\%$ & 100 & 100 & 100 & 100 & 100 \\
\hline$\chi^{2}=2.483$ & & $P=0.870$ & & & & \\
\hline
\end{tabular}

kalmaktadır. Tüm ișletmelerin \%36.9'u aylık 11 ile 20 It arasında süt tüketmektedir. Yapılan $\chi 2$ analizi sonucunda ailelerin süt tüketim düzeylerinin ișletmelerin süt üretimi yapma durumuna bağlı olarak değiștiği belirlenmiștir $\chi 2=24.891 \mathrm{P}=$ 0.000).

Çizelge 8'de görüldüğü gibi ailelerin süt tüketim düzeyleri yaș gruplarına göre incelendiğinde, süt tüketiminin ișletme sahibinin yașı arttıkça azaldığı, ailelerin süt tüketim düzeylerinin ișletme sahibinin yașına bağlı olarak değiștiği belirlenmiștir. $(\chi 2=$ $19.454 \mathrm{P}=0.003)$. Benzer șekilde Onurlubaș ve Çakırlar (2016) gençlerin yașılıara göre daha fazla süt tükettiğini belirtmișlerdir.

Ailelerin süt temin yerleri incelendiğinde, ișletmelerinde süt hayvanı bulunmayan üreticiler büyük oranda komșularından açık süt almakta, ișletmelerin \% \% $u$ ise ambalajlı süt tercih etmektedir (Çizelge 9). Kentsel alanda da hijyen açıdan sakıncalı etkileri bulunan açık sütün aileler arasında tercih edildiğini gösteren araștırmalar da bulunmaktadır. Erdal ve Tokgöz (2011) ailelerin \%67.8'ünün açık sütü tercih ettiğini, \%32.2'sinin ise ambalajlı süte yöneldiğini yaptıkları araștırmada ortaya koymușlardır.

Süt üretimi yapmayan ișletme sahiplerinin süt temininde dikkat ettiği hususlar Çizelge 10'da verilmiștir. Üreticiler süt alırken \%52 oranında hijyenik olmasına dikkat etmektedir. Ayrıca ișletmelerin \%26'sı ise komșuluk-akrabalık ilișkisi nedeniyle süt temin yerini tercih etmektedir. 


\section{SONUÇ VE ÖNERILER}

Türkiye'de nüfusun yaklașı 1/3'ü tarımsal faaliyetlerle geçimini sağlamakta ve bu kesimin büyük çoğunluğu kırsalda özellikle de köylerde yașamaktadır. Araștırmanın inceleme konusu olan süt, insan beslenmesi açısından gereklidir ve Türkiye'nin önemli bir süt üreticisi olması bu yönden avantaj yaratmaktadır. Türkiye İstatistik Kurumu verilerine göre dünyada inek sütü üretiminde 8. sırada yer almaktadır. Üretimin bu derece önemli olușuna karșın tüketim düzeyi beklenenin altındadır. Yapılan araștırmalar ülkemizde süt tüketiminin düșük düzeylerde olduğunu göstermektedir. Bu araștırmada Ankara ili kırsal alanında tarımda faaliyette bulunan tarım ișletmelerinde süt tüketim eğilimi ve etkili faktörler ve faktörler arası ilișkiler ortaya konulmuștur.

Özetle, görüșülen üreticilerin büyük çoğunluğu 50 yaș üzerinde ve ilkokul mezunudur. İșletmelerin aylık ortalama gelirleri 1172 TL ve aylık gıda harcamaları 303 TL'dir. İșletme sahiplerinin hanehalkı genișliği ortalama 3.7 kișidir. Süt tüketimi ortalama olarak aile bașına aylık 11.7 It ve kiși bașına yıllık ise 28.4 It olarak hesaplanmıștır. Bu miktarlar Türkiye ortalamasının altındadır ve kırsal alandaki ailelerin süt tüketimine yeterince önem vermediğini göstermektedir.

Araștırma alanında hanehalklarının süt tüketim düzeylerinin ișletmelerin süt üretme durumuna bağlı olarak değiștiği belirlenmiștir. Üretimin olmadığı hanelerde gıda tüketimi içinde süte fazla yer verilmediği ve bu konuda satın alma gücü yetersizliği yanında alıșkanlığın etkisi ile süt tüketimi için çaba gösterilmediği anlașılmaktadır. Ayrıca süt tüketiminin ișletme sahibinin yașı arttıkça azaldığı ve süt tüketim düzeyinin ișletme sahibinin yașına bağı olarak değiștiği belirlenmiștir. Yapılan araștırmalar ve sağlık uzmanlarının görüșleri, süt tüketiminin özellikle yașlııkta önemli olduğunu ve önceki yașlardaki bu tüketim alıșkanlığının insanları birçok hastalık ve rahatsızlıklara karșı koruduğunu ortaya koymaktadır (Ünal ve Besler, 2008). Bu nedenle tüketimin sadece çocuklar için değil, aynı zamanda her yaștan insanlar için artırıması yönünde bilinç çalıșmalarına gerek vardır.

Araștırma sonuçlarına göre Ankara ilinde kırsal alanda yașayan, tarım sektöründe faaliyet gösteren ailelerin süt tüketim düzeyleri oldukça düșüktür. Büyük çoğunluğunun çocuk sahibi olduğu, yoğun fiziksel aktivite gerektiren tarım sektöründe çalıștıkları düșünüldüğünde, makro ve mikro besin öğelerinin büyük bir bölümünü içinde barındıran süt tüketiminin azlığı dikkat çekmekte ve artırılma gerekliliği ortaya çıkmaktadır. Bu süreçte tüketim bilincine yönelik çalıșmalar artırılarak yapılmalıdır. Okulda yer alan çocuklara okul sütü gibi programların tüm yıla yayılarak devam etmesi önemlidir. Bu arada sütün her yaș ve dönem için önemini anlatan basılı ve görsel yayınlara önem verilmelidir. Tüketim bilincin artıșında aileden, okuldan, çevreden ve makro düzeyde hükümet uygulamalarından yararlanmak gerekir. Konuyla ilgili bilinçlendirme çalıșmaları özellikle kırsal alanda yașayan ailelere dengeli beslenme için gerekli olan gıda ürünleri hakkında bilgi verilmesi ve bunun içinde de süt tüketimine gereken önemin verilmesine yönelik sistematik çalıșmalara gerek vardır.

\section{KAYNAKLAR}

Akbay C, Tiryaki G.Y (2007). Tüketicilerin Ambalajlı ve Açık Süt Tüketim Alıșkanlıklarının Karșılaștırmalı Olarak İncelenmesi: Kahramanmaraș Örneği. KSÜ Fen ve Mühendislik Dergisi, 10(1): 89-96.

Anonim (2016a).http://www.milliyet.com.tr/sut-gunlukbesin-ihtiyacinin-pembenar-detay-sagliklibeslenme-2191099/ Erișim Tarihi: 12.12.2016

Anonim (2016b).http://mww.pinarsutum.com/yasagore-sut-tuketimi Erișim Tarihi:12.12.2016

Anonim (2016c). http://m.gidagundemi.com/haber/ turkiyede-sut-ve-sut-urunleri-tuketimi-h9619.html Erișim Tarihi: 15.12.2016

Armağan G, Akbay C(2007). An Econometric Analysis of Urban Households' Animal Products Consumption in Turkey, Applied Economics, 1-8.

Çelik Y, Karlı B, Bilgiç A, Celik S (2005). Șanlıurfa İli Kentsel Alanda Tüketicilerin Süt Tüketim Düzeyleri ve Tüketim Alıșkanlıkları, Tarım Ekonomisi Dergisi 2005; 11(1) : 5 - 12.

Çetinkaya A. (2010). Kafkas Üniversitesi Öğrencilerinin İçme Sütü ve Süt Ürünlerini Tüketim Alıșkanlıklarının Belirlenmesi. Atatürk Üniversitesi Veteriner Bilimleri Dergisi. 5 (2), 73-84.

Düzgüneș O, Kesici T, GürbüzF (1993). İstatistik Metotları (II. Baskı). Ankara Üniversitesi Ziraat Fakültesi Yayınları No:1291, Ders Kitabı: 369, 218 s., Ankara

Erdal G, Tokgöz K (2011). Tüketicilerin Ambalajlı ve Açık Süt Tüketim Tercihlerini Etkileyen Faktörler: Erzincan İli Örneği, KMÜ Sosyal ve Ekonomik Araștırmalar Dergisi 13 (20): $111-115,2011$

Grigg D (1999). Food Consumption in the Mediterranean region. Tijdschrigt Voor Economische en Sociale Geografie, 90(4): 391-409. 
Güngör M, Bulut Y (2008). Ki-Kare Testi Üzerine. Doğu Anadolu Bölgesi Araștırmaları, Elazığ.

Hanta B (1994). Adana ili Kentsel Alanda Hayvansal Gıda Tüketim Yapısı (yüksek lisans tezi, basılmamıș). C..Ü., Fen Bilimleri Enstitüsü, Adana.

Onurlubaș E, Çakırlar H (2016).Tüketicilerin Süt ve Süt Ürünleri Tüketimini Etkileyen Faktörlerin Belirlenmesi Üzerine Bir Araștırma, Çankırı Karatekin Üniversitesi Sosyal Bilimler Enstitüsü Dergisi, 7(1): 217-242.

Sokal R.R, Rohlf F.J (1995). Biometry. The principles and practice of statistics in biological research. Third edition. W.H. Freeman Company. New York.
Șimșek O, Çetin C, Bilgin, B (2005). “istanbul Illinde İçme Sütü Tüketim Alıșkanlıkları ve Bu Alıșkanlıkları Etkileyen Faktörlerin Belirlenmesi Üzerine Bir Araștırma", Tekirdağ Ziraat Fakültesi Dergisi, 2, 1.

Tuik (2016). İstatistiksel Veriler, www.tuik.gov.tr

Ünal N.R, Besler H.T (2008). Beslenmede Sütün Önemi, Sağlık Bakanlığı Yayın No: 727, Ankara.

Yamane T. (2001). Temel Örnekleme Yöntemleri. (Birinci BaskI). Ceviren: Alptekin ESIN, M. Akif BAKIR, Celal AYDIN ve Esen GÜRBÜZSEL. İstanbul. Literatür Yayıncılık. 


\title{
Yarı Nemli llıman İklim Koșullarında Farklı Eğim ve Farklı Arazi Örtüsü Altında Toprak Gelișimi ve Agregat Stabilitesi Değișimi
}

\author{
Tülay TUNÇAY* $\quad$ Orhan DENGiZ² \\ 'Toprak, Gübre ve Su Kaynakları Merkez Araștırma Enstitüsü Müdürlüğü, Ankara \\ ²Ondokuz Mayıs Üniversitesi, Ziraat Fakültesi, Toprak Bilimi ve Bitki Besleme Bölümü, Samsun
}

*Sorumlu yazar e-posta (Corresponding author e-mail): tulaytuncay@gmail.com

Geliș tarihi (Received) : 18.01.2017

Kabul tarihi (Accepted): 06.03.2017

\section{Öz}

Bu çalıșmanın amacı, aynı ana materyal, farklı eğim ve arazi kullanım koșulları altında toprak gelișimi ve suya dayanıklı agregat stabilitesi değișimini incelemektir. Bu çalıșma, Samsun-Bafra karayolunun güneyinde, Engiz Beldesine bağlı Dağköy mevkii alanı içerisinde farklı topografik pozisyonlarda yer alan bazaltik ana materyal üzerinde olușmuș topraklarda yürütülmüștür. Bu kapsamda, kesit üzerinde kuzey ve güney yönde altı profil seçilmiș ve incelenmiștir. Araștırma sonucuna göre, kesit üzerinde eğimli yamaç arazilerde yer alan topraklar Entisol ordosundan Lithic Ustorthent alt grubunda sınıflandırılırken, düz düze yakın eğimli taban ve tepe/plato düzlüklerinde yer alan topraklar ise Inceptisol ve Vertisol ordolarına ait Typic Haplustert, Vertic Haplustept ve Typic Haplustept olarak sınıflandırılmıștır. Çalıșma alanı içerisinde aynı ana materyal üzerinde farklı toprakların olușması, diğer bir ifade ile genç ve olgun toprakların lokal bir alan içerisinde birlikte yer almaları, topografya veya lokal rölyefin toprak olușum sürecinde ana materyal ve zaman üzerinde önemli etkisi olduğunu göstermektedir. Ayrıca, bu duruma toprakların üzerinde yer alan vejetasyonun sıklığı, çeșidi gibi faktörlerin de önemli etki yaptığı görülmüștür. Toprakların olgunlașmasında veya genç kalmalarında özellikle yamaç arazilerde yer alan topraklarda su hareketi dolayısıyla toprak tașınımı ve birikiminin yerinde olușum kadar etkili olduğu görülmektedir. Taban ve etek arazilerde yer alan ve kuru tarım olarak kullanılan Typic Haplustert ve Vertic Haplustept topraklara ait üst katmanda suya dayanıklı agregat değerleri ile mera olarak kullanılan tepe üstü düzlük üzerinde yer alan Typic Haplustept'in değerleri arasında önemli farklılık olduğu belirlenmiștir ve bu farklı̆̆ın özellikle toprakların tarımsal kullanım ve organik madde içeriklerinden kaynaklandığı düșünülmektedir. Orman ve mera arazi örtüsü altında yamaç araziler üzerinde yer alan Lithic Ustorthent olarak sınıflandııılan topraklarda ise agregat değerleri yaklașık aynı düzeyde olup \% 63.28 ile \% 70.16 arasında değișmektedir.

Anahtar Kelimeler: Toprak olușumu, toprak sınıflaması, agregat stabilitesi, arazi kullanım-arazi örtüsü, topoğrafik pozisyon

\section{Variation of Aggregate Stability and Soil Development with Different Slope and Land Cover under Semi Moist Humid Climate Conditions}

\begin{abstract}
The aim of this study is to examine the changes in soil development and water-resistant aggregate stability on the same parent material, but with different slopes, land cover and land use under semihumid climatic conditions. It was carried out on the soil formed on the basaltic parent material in
\end{abstract}


different topographical positions within the Dağköy area of Engiz Country, which is located at the south of the Samsun-Bafra Highway. In this context, six soil profiles were selected on north and south transect direction and examined. According to the study results, the lands located on sloped fields were classified in the Lithic Ustorthent subgroup of the Entisol order, while the lands on the lowersloped fields and the hill/plateau plains were classified as Typic Haplustert, Vertic Haplustept and Typic Haplustept, belonging to the Inceptisol and Vertisol orders. The formation of different soils on the same parent material in the study area - in other words, young and mature soils co-existing in a local area - suggests that topography or local relief has a significant impact on the material and time involved in the soil formation process. In addition, factors including the frequency and variety of vegetation on the land have also been shown to have an important effect. It is seen that in the maturation of the soil and in the process that keeps the soil young, the soil transport and accumulation, especially in the soils located on the slopes due to water movement, is as effective as the formation that occurs on the spot. A significant difference was determined between the upper layer water-resistant aggregate values of Typic Haplustert and Vertic Haplustept soils used as dry agriculture - at the flat and foothill fields - compared to the values of the Typic Haplustept soil used as pasture on the upper plains, and this difference is thought to be caused in particular by agricultural use of the soils and by their organic matter content. In the soil classified as Lithic Ustorthent on the sloped land under the forest and pasture lands, the aggregate values were about the same level, ranging from $63.28 \%$ to $70.16 \%$.

Key Words: Soil formation, soil classification, aggregate stability, land use-land cover, topographic position

\section{Giriș}

Toprak yașamın temel parçalarından en önemlisi ve sürekli değișme halinde olan karmașık bir sistemdir. Toprakların olușumu ve gelișimi esnasında çeșitli ayrıșma, parçalanma, tașınma, birikme, yeni ürünlerin olușumu gibi birçok toprak yapan olaylar ön plana çıkmaktadır. Aynı zamanda topraklar ana materyal üzerine, topoğrafya, iklim, canlıların ve toprak olușunun devam ettiği sürenin uzunluğunu ifade eden zamanın etkisiyle gelișim gösterir ve karakter kazanırlar (Jenny, 1941).

Toprak olușumu sırasında topoğrafya, solumun kalınlığı, profilin ıslaklığı, rengi, horizon farklılașmasının derecesi, A horizonunun organik madde miktarı, çözünebilir tuz miktarı gibi çok sayıda etmenin, toprak reaksiyonu üzerine aktif rol oynadığı bilinmektedir (Tanju, 1996). Toprakların bilinçli ve dengeli bir șekilde kullanılabilmesi için toprak olușum ve gelișim süreçlerinin ortaya konulması ve fiziksel ve kimyasal özelliklerinin belirlenmesi gerekmektedir. Toprakların agregatlașma derecesi ve buna bağlı olarak meydana gelen strüktürün korunumu ve devamlılığı, erozyonun önlenmesi ve bitki yetiștirilmesi açısından önemlidir. Agregat dayanıklığı üzerine organik madde, kil miktarı ve tipi, oksit miktarının etkili olduğu (Oades, 1984; Öztürkmen ve Savaș, 2014) bilinmektedir.
Bununla birlikte organik karbon makro agregat dağıımında, seskioksitler ise mikro agregat dağıımında etkili olmaktadır (Yao vd., 1990).

Bu çalıșmanın amacı, benzer ana materyal, farklı topoğrafya ve arazi kullanım-arazi örtüsü altında olușmuș altı toprak profilindeki lokal değișimlerin incelenmesi ve toprakların agregat stabilite durumlarının belirlenmesidir.

\section{MATERYAL ve YÖNTEM}

\section{Araștırma Alanı Genel Özellikleri}

Engiz Çayı havzası Karadeniz Bölgesi'nin Orta Karadeniz Bölümünde, Bafra Ovasının kuzeyinde, Samsun ili sınırları içerisindeyer alır. Araștırma sahası Engiz Çayı havzası așağı çığııında, Dağköy mevkii alanı içerisinde kalan, kuzey-güney doğrultu kesiti ve deniz seviyesinden $20 \mathrm{~m}$ ile $300 \mathrm{~m}$ arasında yükselti değișkenliğinde bulunmaktadır.

Sahanın olușum ve gelișiminde Engiz Çayı büyük rol oynamaktadır. Araștırma sahası ve yakın çevresinde yüzeylenen en geniș birim Yenikonak formasyonudur, volkano sedimanter kayaçlardan olușmaktadır. Büyük çoğunluğu tüf, tüfit, bazalt, kumlu kireçtașı ve marn ara seviyeli kumtașı-șeyl ardalanmasından olușmaktadır (Gedik ve Korkmaz, 1984). Dikkate alınan bazalt ana materyali üzerinde 
Çizelge 1. Bafra'nın uzun yıllar (1975-2010) ortalama aylık yağıș sıcaklıklarının dağılımı

Table 1. Long term monthly average rainfall and temperature distribution of Bafra

\begin{tabular}{llllllllllllll}
\hline Aylar & $\mathrm{O}$ & $\mathrm{S}$ & $\mathrm{M}$ & $\mathrm{N}$ & $\mathrm{M}$ & $\mathrm{H}$ & $\mathrm{T}$ & $\mathrm{A}$ & $\mathrm{E}$ & $\mathrm{E}$ & $\mathrm{K}$ & $\mathrm{A}$ & Ylllik \\
\hline $\mathrm{T}$ & 5.7 & 5.6 & 7.2 & 10.9 & 15.1 & 19.8 & 22.6 & 22.6 & 19.0 & 14.9 & 11.0 & 7.6 & 13.5 \\
$\mathrm{P}$ & 81.6 & 65.7 & 60.3 & 56.9 & 47.8 & 48.3 & 30.9 & 42.2 & 61.3 & 101.6 & 98.3 & 100.6 & 794.4 \\
\hline
\end{tabular}

T: Sıcaklık ( $\left.{ }^{\circ} \mathrm{C}\right)$, P: Yağıș ortalaması $(\mathrm{mm})$

olușan topraklarda mera alanları ile kuru tarım yapılan alanlar yer almakta olup, çok az olsa da meșelerden olușan ormanlık alanlar mevcuttur.

Çalıșma alanı içerisinde meteorolojik ölçüm istasyonu bulunmamaktadır. Bu nedenle araștırma alanı çevresindeki istasyonlar esas alınmıștır. Araștırma sahasında yılın en soğuk ayı Șubat'ır $\left(5.6^{\circ} \mathrm{C}\right)$. En sıcak aylar ise Temmuz ve Ağustos aylarıdır $\left(22.6^{\circ} \mathrm{C}\right)$. Yılın dört ayında (Aralık, Ocak, Șubat, Mart) ortalama sıcaklıklar $10^{\circ} \mathrm{C}$ 'nin altında kalırken Nisan ayından itibaren yükselmektedir. İlkbahar dönemlerinde düzenli bir sıcaklık artıșı ve sonbahar dönemlerinde düzenli bir azalma olduğu görülmektedir (Çizelge 1). Sıcaklıkların 0oC'nin altına düșmesi don olaylarına sebep olur ve dolaylı olarak özellikle ana kayanın ortaya çıtığı yerlerde morfolojik değișimi hızlandıır. Araștırma sahasında ortalama yağıș miktarı yaklașık 800 mm'lerde değișiklik göstermektedir. Araștırma sahası uzun yıllar aylık yağıș ortalamaları en düșük yağıș miktarının Temmuz (30.9 mm) ve Ağustos (42.2 mm) aylarında olduğunu göstermektedir. En yüksek yağıș miktarı ise Ekim (101.6 mm) ayındadır.
Çalıșma alanına ait su bilançosu diyagramına göre, Nisan ayı ortalarından Eylül ayının sonlarına kadar buharlașma değerleri yağıș değerlerinden daha yüksektir. Nisan sonlarından Haziran sonlarına kadar birikmiș su kullanılmaktadır. Bu yüzden bu aylarda kuraklık etkili değildir. Temmuz ayından itibaren Eylül ayının ortalarına kadar yaklașık üç buçuk aylık bir süre kurak geçmektedir (Șekil 1). Araștırma sahası iklim verileri De Martonne formülü kullanılarak değerlendirilmiștir. Bu formüle göre sahanın yıllık indis değeri 33.8'dir. Bu değere göre saha nemli iklim sahası içerisinde kalmaktadır. Araștırma sahası Köppen'e göre Orta İklimler Kușağı́nda yer alır ve Csb harfleriyle ifade edilen kıșı ılık, yazı sıcak, kurak fakat kısa iklim sınıfının özelliğini gösterir.

Araștırma alanında $150 \mathrm{~m}$ seviyelerinde bir așınım yüzeyi bulunmaktadır. Bu așınım yüzeyi Dağköy ve çevresinde net olarak izlenebilmektedir. Araștırma sahasının batısında Akkan (1970) Kızılırmak Deltası'nı incelerken 120-130 m yükseklikteki düzlüklerden bahsetmiș ve bunların eski delta seviyesinin ana kaya üzerindeki devamı

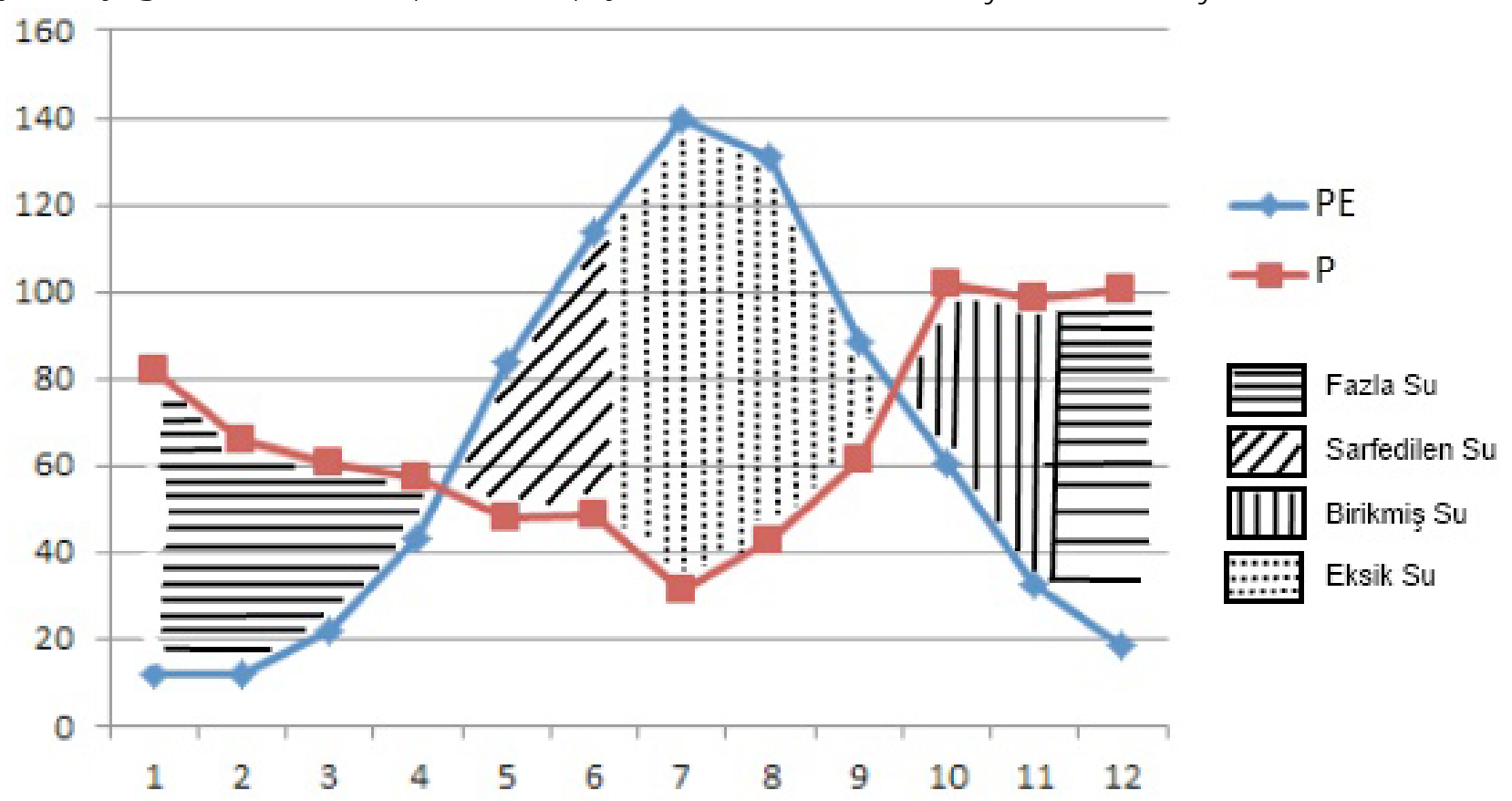

Șekil 1. Bafra'nın su bilançosu diyagramı (Thornthwaite, 1948)

Figure 1. Bafra's water balance diagram ((Thornthwaite, 1948) 


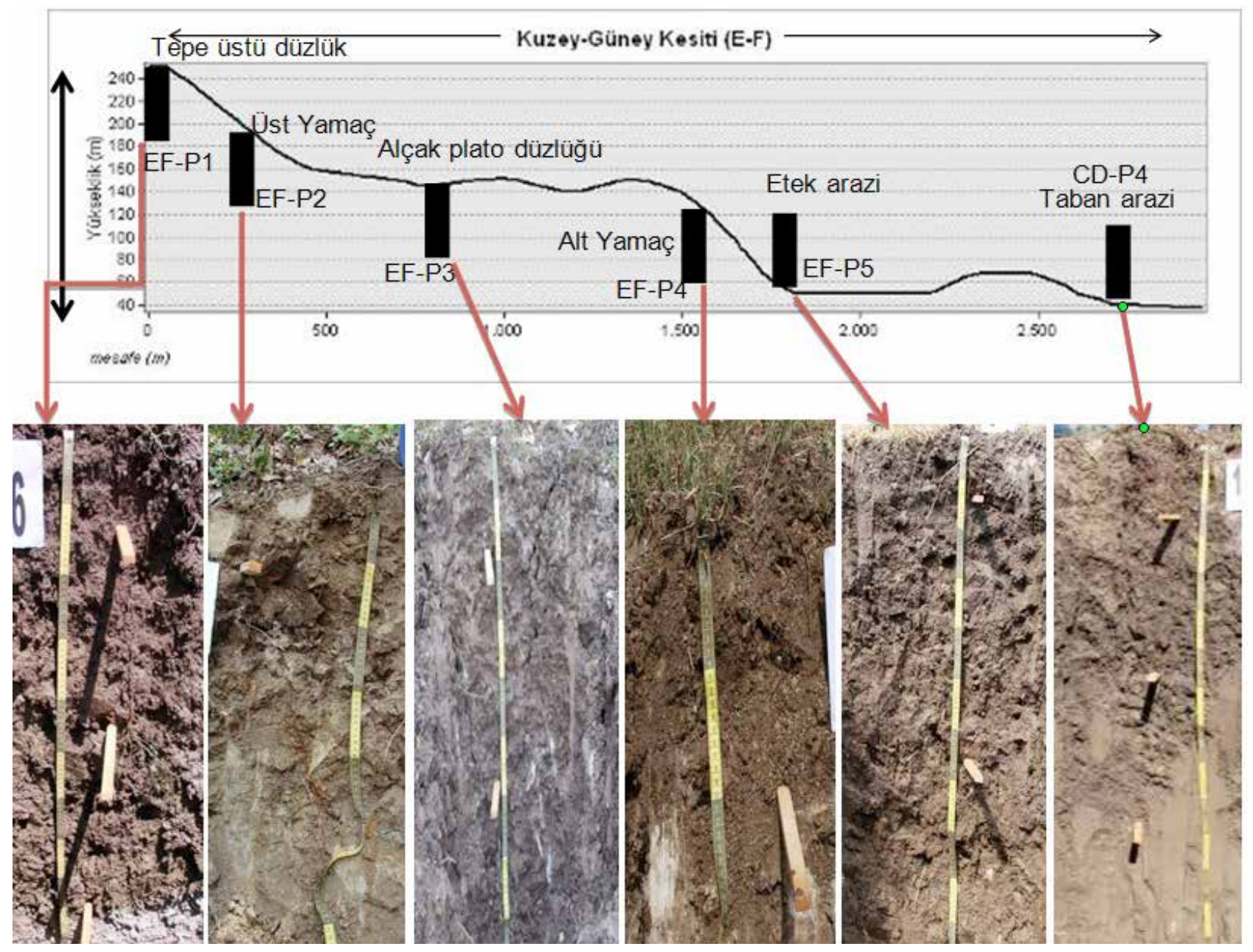

Șekil 2. Güneybatı-Kuzeydoğu doğrultusunda yer alan farklı topoğrafik pozisyonda açılan profiller

Figure 2. Profiles opened in different topographical positions in the Southwestern-Northeast Direction

durumunda olmaları nedeniyle, eski deltanın gelișmiș olduğu taban seviyesine göre teșekkül etmiș "kıyı așınım düzlükler" olduğu sonucuna varmıștır. Bu duruma göre Dağköy așınım yüzeyinin seviye ve olușum bakımından eski deltaya benzerlik gösterdiği söylenebilir. Bu yüzey Dağköy așınım yüzeyi olarak isimlendirilmiștir.

Bu araștırma farklı topoğrafik pozisyonlarda (tepe üstü düzlük, yamaç, etek ve taban araziler) yer alan bazaltik ana materyal üzerinde olușmuș toprakların fiziksel, kimyasal ve morfolojik özelliklerinin belirlenmesi, toprak olușum süreçleri ortaya konulması ve bu süreçlerin agregat stabilitesi üzerindeki değișimlerini belirlemek amacıyla planlanmıștır. Bu amaçla araștırma, Engiz Çayı havzası içerisinde olan, deniz seviyesinden 20 m ile 300 m arasında yükselti değișkenliği olan kuzey-güney doğrultusu üzerinde yaklașık 9.5 km²'lik alanda yürütülmüștür. Araștırma alanına ait 1:25.000 ölçekli topoğrafik harita CBS ortamında sayısallaștırılarak alana ait eș yükselti, eğim ve kabartı haritaları olușturulmuștur. Araștırma alanındaki kesit üzerindeki arazi șekli ve açılan profillerin șematik gösterimi Șekil Z'de verilmiștir.

Açlan her bir profil çukurundan horizon esasına göre $(1.5-2 \mathrm{~m})$ toprak örneklemeleri yapılarak laboratuvara getirilmiș ve analiz ön ișlemlerine tabi tutulmuștur. Analizlere hazır hale getirilen topraklarda fiziksel, kimyasal ve morfolojik analizler yapılmıștır. Toprakların morfolojik tanımlamaları için açilan her profil Soil Survey Manual (1993) tarafından belirtilen usuller esas alınarak incelenmiștir. Horizonların tanımı ve adlandırıması ise Soil Survey Staff (1999)'a göre yapılmıștır.

Profillerden alınan bozulmuș toprak örneklerinde bünye (Bouyoucos, 1951), suya dayanıklı agregat stabilitesi (SDA) (Kemper ve Rosenau, 1986), değișebilir katyonlar $\mathrm{pH}^{\prime}$ sI 8.2'ye ayarlı sodyum asetat ( $\mathrm{NaOAc}$ ) kullanılarak (Rhoades, 1986), serbest karbonatların analizinde 
Scheibler kalsimetresi kullanılarak (Soil Survey Staff, 1993), toprak reaksiyonu $(\mathrm{pH})$ saturasyon çamurunda $\mathrm{pH}$ metre kullanılarak (Soil Survey Laboratory, 1992; 2004), elektriksel iletkenlik saturasyon çamurunda kondaktivimetre aleti kullanılarak (Soil Survey Labrotory, 1992; 2004), organik madde analizi Walkley-Black yönteminin Jackson tarafından modifiye edilmiș șekli ile yapılmıștır (Jackson, 1958).

\section{BULGULAR ve TARTIȘMA}

\section{Kesit Üzerinde Yer Alan Toprakların Fiziksel ve Kimyasal Özellikleri}

Kuzey-güney doğrultusunda yer alan farklı topografik pozisyonda (tepe üstü düzlük, üst yamac, alt yamac, etek ve taban) ve arazi kullanımlarında (tarım, orman ve mera) açılan altı farkı profile ait arazi kullanımı, topografik pozisyonları, yükseltileri, fiziksel ve kimyasal analiz sonuçları Çizelge $2^{\prime}$ de verilmiștir.

CD-P4 nolu profil, taban arazi üzerinde olușmuș düz ve düze yakın eğimli, derin topraklardır. Tüm profil kil bünyeli olup, kil \% 56.2 ile \% 78.2 arasında değișmektedir. Bu durumun toprakların saturasyon değerlerini doğrudan etkilemesi nedeniyle, özellikle kil

Çizelge 2. Kesit üzerinde yer alan toprakların fizyografya, arazi kullanım, yükseklik, fiziksel ve kimyasal analiz sonuçları Table 2. Physiography, land use, elevation, physical and chemical analysis results of soils on the transect

\begin{tabular}{|c|c|c|c|c|c|c|c|c|c|c|c|c|c|}
\hline \multirow[t]{2}{*}{ Horizon } & \multirow[t]{2}{*}{$\begin{array}{l}\text { Derinlik } \\
(\mathrm{cm})\end{array}$} & \multirow[t]{2}{*}{$\mathrm{pH}$} & \multirow[t]{2}{*}{$\begin{array}{c}\mathrm{EC} \\
\mathrm{dS} . \mathrm{m}^{-1}\end{array}$} & \multirow[t]{2}{*}{$\begin{array}{c}\text { Kireç } \\
\%\end{array}$} & \multirow[t]{2}{*}{$\begin{array}{l}\mathrm{OM} \\
\%\end{array}$} & \multicolumn{3}{|c|}{$\begin{array}{l}\text { Değișebilirler Katyonlar } \\
\text { cmol. } \mathrm{kg}^{-1}\end{array}$} & \multicolumn{4}{|c|}{ Bünye \% } & \multirow[t]{2}{*}{ SDA \% } \\
\hline & & & & & & $\mathrm{Na}+$ & $\mathrm{K}+$ & $\mathrm{Ca}+++\mathrm{Mg}++$ & C & $\mathrm{Si}$ & $S$ & Sinıf & \\
\hline \multicolumn{14}{|c|}{ CD-P4 / Taban / Kuru Tarım / 25 m } \\
\hline Ap & $0-23$ & 7.50 & 0.17 & 0.20 & 1.65 & 0.22 & 1.67 & 40.91 & 56.2 & 23.1 & 20.7 & C & 7.16 \\
\hline Bss 1 & $23-65$ & 7.30 & 0.44 & 0.98 & 1.26 & 0.25 & 1.47 & 39.64 & 62.6 & 12.8 & 24.5 & C & 17.71 \\
\hline Bss2 & $65-106$ & 8.25 & 0.17 & 1.10 & 1.09 & 1.33 & 1.41 & 37.59 & 68.4 & 15.8 & 15.8 & C & 18.03 \\
\hline C & $106+$ & 8.14 & 0.11 & 2.67 & 0.14 & 1.35 & 1.40 & 36.04 & 78.4 & 2.8 & 18.8 & C & 4.20 \\
\hline \multicolumn{14}{|c|}{ EF-P5 / Etek /Tarım / 50 m } \\
\hline Ap & $0-15$ & 8.28 & 0.26 & 0.79 & 2.21 & 0.36 & 0.36 & 42.97 & 58.3 & 20.0 & 21.7 & C & 21.61 \\
\hline Bw & $15-66$ & 8.12 & 0.18 & 1.26 & 0.67 & 0.47 & 0.32 & 42.58 & 61.9 & 25.6 & 12.5 & C & 18.19 \\
\hline $2 \mathrm{Cr}$ & 66-106 & 8.20 & 0.25 & 1.75 & 0.55 & 1.02 & 0.26 & 26.49 & 37.3 & 34.8 & 27.9 & $\mathrm{CL}$ & 5.16 \\
\hline \multicolumn{14}{|c|}{ EF-P4 /Alt Yamaç / Mera /132 m } \\
\hline A & $0-19$ & 7.89 & 0.40 & 0.39 & 3.37 & 0.16 & 0.49 & 41.02 & 32.5 & 18.6 & 48.9 & $S C L$ & 70.16 \\
\hline R & $19-32$ & - & - & - & & - & - & - & - & - & - & - & \\
\hline \multicolumn{14}{|c|}{ EF-P3 / Alçak Plato / Orman / 160 m } \\
\hline A & $0-18$ & 7.06 & 0.44 & 1.08 & 1.88 & 0.24 & 0.32 & 46.71 & 54.4 & 22.6 & 23.1 & C & 35.13 \\
\hline Bw & $18-57$ & 7.31 & 0.42 & 1.02 & 0.06 & 0.34 & 0.09 & 50.11 & 61.1 & 17.7 & 21.2 & C & 28.38 \\
\hline $\mathrm{Cr}$ & $57-87$ & 7.01 & 0.51 & 0.39 & 0.57 & 0.58 & 0.09 & 39.87 & 57.5 & 22.6 & 19.9 & C & 6.34 \\
\hline \multicolumn{14}{|c|}{ EF-P2 / Üst Yamaç / Orman / 190 m } \\
\hline$A$ & $0-11$ & 6,74 & 0.35 & 0.09 & 1.54 & 0.35 & 0.43 & 27.92 & 22.0 & 21.8 & 56.2 & SL & 63.28 \\
\hline $\mathrm{Cr}$ & $11-65$ & 7.01 & 0.20 & 0.29 & 0.87 & 0.54 & 0.12 & 17.00 & 14.6 & 9.3 & 76.1 & LS & 7.39 \\
\hline \multicolumn{14}{|c|}{ EF-P1 / Tepe Üstü Düzlük / Mera / 251 m } \\
\hline A & $0-12$ & 7.14 & 0.55 & 0.69 & 3.53 & 0.29 & 0.58 & 48.85 & 61.9 & 23.6 & 14.5 & C & 36.23 \\
\hline Bw1 & $12-41$ & 7.70 & 0.54 & 0.98 & 1.78 & 0.27 & 0.31 & 43.98 & 49.9 & 27.7 & 12.5 & C & 14.09 \\
\hline Bw2 & $41-84$ & 7.92 & 0.11 & 0.98 & 1.41 & 0.64 & 0.29 & 51.62 & 47.9 & 32.3 & 19.8 & C & 7.77 \\
\hline $2 \mathrm{Ck}$ & 84-105 & 7.94 & 0.38 & 6.37 & 1.29 & 0.63 & 0.09 & 43.74 & 40.0 & 40.8 & 19.1 & C & 3.37 \\
\hline
\end{tabular}

EC: Elektriksel iletkenlik, OM: Organik madde, C: Kil, Si: Silt, S: Kum, SDA: Suya dayanıklı agregat 
miktarının derinlikle artıșı, toprakların sature olma durumlarını da arttırmaktadır. KDK'ları yüzeyde organik madde miktarının yüksekliği ve kil içeriği nedeniyle $42.80 \mathrm{cmol} \mathrm{kg}^{-1}$ olmasına karșın derinlere doğru bu miktar düșüș göstermektedir. Bu durum organik madde miktarı için de geçerli olup yüzeyde \% 1.65 olmasına karșın 105 cm den sonra \% 0.14'e düșmektedir. Toprak reaksiyonu hafif alkalin olup $\mathrm{pH}$ değerleri 7.05 ile 8.25 arasında değișmektedir. Kireç profilde çok az miktarda olup yüzeyde \% 0.20 iken derinde bir miktar artarak \% 2.67 olmaktadır. Topraklarda baskın değișebilir katyonlar Ca ve Mg iyonlarıdır. Topraklarda tuzluluk ve alkalilik problemi görülmemektedir.

Kuzey-güney doğrultusunda yer alan farklı topografik pozisyonlardan etek arazi üzerinde açılan EF-P5 kodlu toprak profili, orta derin ve ağır bünyelidir. 66 cm derinliğe kadar kil \% 58.3 ile \% 61.9 arasında değișmektedir. Toprakların katyon değișim kapasiteleri (KDK) yüzeyde organik madde miktarı ve kil içeriği nedeniyle 43.69 cmol.kg-1 olmasına karșın 66 cm'den sonra 27.77 cmol.kg-1' e düșmektedir. Benzer șekilde organik madde miktarı içinde geçerli olup yüzeyde \% 2.21 olmasına karșın yüzey altı katmanda \% 0.55'e düșmektedir. Toprak reaksiyonu alkalin olup $\mathrm{pH}$ değerleri 8.12 ile 8,28 arasında değișmektedir. Kireç profilde çok az miktardadır ve \% 0.79-1.75 arasında değișmektedir. Topraklarda baskın değișebilir katyonlar Ca ve Mg iyonlarıdır. Topraklarda tuzluluk ve alkalilik problemi görülmemektedir.

EF-P4 kodlu profil kuzey-güney doğrultusunda yer alan kesiti üzerinde deniz seviyesinden 132 m yükseklikte yer alan profil olup, fizyografik açıdan yamaç arazidir. Yüzey örtüsü çok zayıf olması ve dik eğimli olmaları nedeniyle erozyon șiddeti fazla, bundan dolaysıda topraklar çok sığ derinliğe $(19 \mathrm{~cm})$ sahiptirler. Yüzey toprakları kaba bünyeli olup kumlu kil tındır. KDK ve organik madde içerikleri yüzey toprağında $41.67 \mathrm{cmol}$. $\mathrm{kg}^{-1}$ ve \% 3.37 dir. Toprak reaksiyonu hafif alkalin olup, pH değerleri 7.89' dir. Kireç profilde çok az olup \% 0.39'dur. Topraklarda baskın değișebilir katyonlar Ca ve Mg iyonlarıdır. Topraklarda tuzluluk ve alkalilik problemi görülmemektedir.

EF-P3 kodlu profil deniz seviyesinden 160 m yükseklikte yer alan alçak plato üzerinde olușmuș, hafif eğime sahip derin topraklardır. Üzerinde genellikle orman ve mera örtüsü bulunduran bu arazilerdeki topraklar, ağır bünyelidirler. Kil profilde \% 54.4 ile \% 61. 1 arasında değișmektedir. Bu durum ağır bünyeye sahip profillerde olduğu gibi, toprakların doygunluk olma durumlarını doğrudan etkilemeleri nedeniyle özellikle kil miktarının derinlikle artıșı, toprakların suyla doygun olma durumlarını da arttırmaktadır. KDK'ları 40.54 ile 50.54 cmol.kg-1arasında değișmektedir. Organik madde miktarı yüzeyde \% 1.88 iken derinlere doğru bu oran hızlı bir șekilde düșmektedir. Toprak reaksiyonu hafif alkalin olup $\mathrm{pH}$ değerleri 7.01 ile 7.31 arasında değișmektedir. Kireç profilde çok az miktarda olup yüzeyde \% 1.08 iken derinde azalarak \% 0.39 olmaktadır. Topraklarda baskın değișebilir katyonlar Ca ve Mg iyonlarıdır. Topraklarda tuzluluk ve alkalilik problemi görülmemektedir.

EF-P2 kodlu profil kuzey-güney doğrultusunda yer alan kesit üzerinde deniz seviyesinden 190 m yükseklikte yer almakta profil olup, fizyografik arazi șekli yamaçtır. Çok sığ derinliğe $(11 \mathrm{~cm})$ sahip, kumlu tın bünyelidirler. Kil ve organik madde içerikleri diğer profillere göre çok düșük seviyelerde olmaları nedeniyle KDK 17.66 ile $28.70 \mathrm{cmol} . \mathrm{kg}^{-1}$ arasında değișmektedir. Toprak reaksiyonu, nötr olup, pH değerleri 6.74 ile 7.01 arasında değișmektedir. Kireç profilde çok az olup \% 0.09 ile \% 0.29 arasındadır. Topraklarda baskın değișebilir katyonlar Ca ve Mg iyonlarıdır. Topraklarda tuzluluk ve alkalilik problemi görülmemektedir.

EF-P1 kodlu profil kuzey-güney kesiti üzerinde deniz seviyesinden $251 \mathrm{~m}$ ile en yüksekte yer alan profil olup, tepe üstü düzlükler üzerinde yer alan arazilerde yayılım göstermektedir. Tüm profil kil bünyeli olup, kil \% 40.0 ile \% 61.9 arasında değișmektedir. Bu durum toprakların doygun olma durumlarını doğrudan etkilemeleri nedeniyle özellikle kil miktarının derinlikle artıșı, toprakların sature olma durumlarını da arttırmaktadır. KDK'ları, yüksek kil içeriği nedeniyle 44.46 ile $52.55 \mathrm{cmol} \mathrm{kg}^{-1}$ arasında değișmektedir. Toprak reaksiyonu hafif alkalin olup $\mathrm{pH}$ değerleri 7.14 ile 7.94 arasında değișmektedir. Kireç profilde az miktarda olup yüzeyde \% 0.69 iken derinde bir miktar artarak \% 6.37 olmaktadır. Topraklarda baskın değișebilir katyonlar Ca ve Mg iyonlarıdır. Topraklarda tuzluluk ve alkalilik problemi görülmemektedir. 


\section{Toprakların Toprak Taksonomisine göre Sınıflandırılması}

Çalıșma alanı topraklarının toprak taksonomisine göre sınıflandırıması, toprakların pedogenetik özellikleri ile üst tanı horizonları (epipedon) ve bunların altında bulunan yüzey altı tanı horizonları ve özelliklerine göre yapıımıștır. Toprakların olușum süreci sonrası olușan bazı yüzey üstü ve yüzey altı tanı horizonları saptanmıș ve bunlar Entisol, Inceptisol ve Vertisol, ordolarına yerleștirilmiștir (Soil Survey Staff, 1999).

Kesit üzerinde incelenen profillerde eğimi fazla, yamaç arazilere sahip topraklar üzerinde yer alan EF-P4 ve EF-P2 nolu profiller yüzey altı tanı horizonuna sahip olmamaları nedeniyle genç topraklar olarak nitelendirilmekte ve Entisol ordosunda sınıflandırımaktadır. Bu profiller yeterince bitki örtüsünce kaplı olmayan ve yanlıș ișlemeli tarım uygulamaları sonucu eğimli arazilerin erozyona maruz kalmaları nedeniyle yeterince pedogenetik sürece sahip olamayan sığ derinliğe sahip topraklardır. Bu toprakların yüzeyde genellikle bir ochric epipedon ve yüzey altında $50 \mathrm{~cm}$ derinlik içerisinde bir lithic kontak dıșında her hangi bir tanı horizonu bulunmamaktadır. Topraklar yamaç arazi üzerinde yer almaları nedeniyle orthent alt ordosuna nem rejiminden dolayı ustorthent ve Lithic Ustorthent alt ordosunda sınıflandırımıșlardır. Buna karșılık düz düze yakın eğime sahip topografik pozisyonlar üzerinde yer alan EF-P5, EF-P3, EF-P1 kodlu profiller, içerdikleri tanı horizonu (cambic) ile Entisollerden daha ileri bir toprak olușumu göstermeleri nedeniyle Inceptisol ordosuna, toprak nem rejiminin ustic olması sonucu ustept alt ordosuna ve Haplustept büyük grup içerisine yerleștirilmișlerdir. EF-P5 ve EF-P1 nolu profiller yüzeyde vertik özellik göstermeleri nedeniyle Vertic Haplustept, EF-P3 ise büyük grubun özelliklerini tașıması nedeniyle Typic Haplustept olarak sınıflandırılmıștır. CD-P4 nolu profile ait topraklarda șișme özelliğindeki killerin miktarı çok fazla olması (profil boyunca \% 50 ve daha fazla), kurak mevsimlerde yüzeyden derinlere uzanan çatlaklara sahip olmaları ve profil içerisinde yer yer kayma yüzeylerinin görülmesi nedeni ile Vertisol ordosuna yerleștirilmiștir. Ustic nem rejiminden dolayı ustert alt ordosunda, haplustert büyük grubuna profile büyük grubun tüm özellikleri tașımaları nedeniyle Typic Haplustert alt grubuna yerleștirilmiștir.

\section{Toprakların Suya Dayanıklı Agregat Dağılımı}

Bir toprağın agregat stabilitesi, toprağın erozyona mukavemeti ile doğrudan ilgi olması nedeniyleönemlidir. Aynızamanda, agregasyonun bazı toprak özellikleri ile ilișkili olduğu birçok araștırmacı tarafından ifade edilmiștir (Akalan, 1969; Rost ve Rowles, 1940; Aksoy, 1973; Chester vd. 1957). Profillere ait yüzey topraklarında en düșük suya dayanıklı agregat (SDA) değeri, ișlemeli tarımsal faaliyetlerin yapıldığı düz ve düze yakın taban arazi üzerinde yer alan CD-P4 ile kodlanmıș Typic Haplustert topraklarda belirlenmișidir. Yine tarımsal faaliyetlerde kullanılan ve etek arazide yer alan Vertic Haplustept topraklarda ise Typic Haplustert topraklara göre SDA değerleri organik madde miktarı ve az da olsa kil miktarındaki fazlalık nedeniyle biraz daha yüksek olarak belirlenmesine karșılık, her iki toprakların yüzey katları diğer örtü katları altındaki SDA değerlerden düșük olarak belirlenmiștir. Bunun sebepleri toprakların sürekli olarak yoğun tarla trafiğine maruz kalmaları sonucu toprak agregatlarının deformeye uğramasının yanı sıra toprakların ișlemeli tarımsal uygulamalar sonucu organik maddenin hızlı oksidiyona uğraması ile parçalanarak azalmasıdır. Bu durum tanelerin bir araya gelmesinde önemli bir unsurun kaybolmasına neden olmaktadır. Dolayısıyla, toprakların organik madde artıșının sağlanması, bir taraftan toprağın fiziki, kimyasal ve biyolojik yapısını düzeltmekte, diğer taraftan da yağmur damlasının darbe ve akıș hızını azaltması gibi önemli katkı sağlayabilmektedir. Organik madde toprak strüktürünün olușması yardım eder. Özbek vd. (1993), organik maddelerin toprağın üst kısmında agregatların olușumu üzerinde kuvvetli bir etkiye sahip olduğunu ve bu durumun organik materyalin etkisiyle meydana gelmiș agregatların toprağın diğer kısımlarına oranla daha yüksek karbon içeriğine sahip olması ile açıklanabileceğini ayrıca uzun süreli organik gübreleme ile büyük agregatların (> 0,5 mm) oranının artacağını bildirmiștir.

Tepe üstü düz araziler üzerinde yer alan EF-P1 kodlu Vertic Haplustept etek arazi üzerinde dağılım gösteren toprakla aynı taksonomik sınıflama içerisinde yer almalarına karșın SDA değerleri daha yüksek bulunmuștur. Bunun en önemli sebebi bu toprakların yüzeyinin mera ile kaplı olmalarının yanı sıra agregatların sürekli deforme olmasına neden olacak herhangi bir etkenin 
olmamasıdır. Topografik bakımdan özellikle de benzer eğimlere sahip olan EF-P2 ve EF-P4 nolu profillere benzer genetiksel horizon gelișim süreçlerine sahip olmalarına karșın gerek yüzey gerekse de yüzey altı SDA değerlerinde önemli farklııklar belirlenmiștir. Orman ve mera ile kaplı yamaç arazilerde yer alan genç toprakların yüzey topraklarında SDA değerleri ise birbirine yakın olup kesit içerisinde en yüksek değerler olarak belirlenmiștir. Tüm profillerde SDA değerlerinin derinlik artıșı ile azaldığı görülmektedir.

\section{SONUC}

$\mathrm{Bu}$ araștırmada, yarı nemli ılıman iklim koșullarında farklı topografik pozisyonda (tepe üstü düzlük, üst yamaç, alt yamaç, etek ve taban) ve arazi kullanımlarında (tarım, orman ve mera) açılan altı farkı profile ait arazi kullanımı, topografik pozisyonların toprak gelișimi ve agregat stabilitesi üzerindeki değișimleri incelenmiștir. Araștırma alanı aynı ana materyale sahip olmasına karșın, aynı alan içerisinde bu denli iki farklı toprak olușmasının, diğer bir ifade ile geç ve olgun toprakların lokal bir alan içerisinde birlikte yer almalarının sebebi, topografya veya lokal rölyefin, ana materyalin ve zamanın toprak olușum süreci üzerindeki önemli etkisi olmasıdır. Ayrıca bu duruma, toprakların üzerinde yer alan vejetasyonun sıklığı, çeșidi gibi faktörlerin de önemli etki yaptığı görülmüștür. Toprakların olgunlașmasında veya genç kalmalarında özellikle yamaç arazilerde yer alan topraklarda su hareketi dolayısıyla toprak tașınımı ve birikiminin yerinde olușum kadar etkili olduğu görülmektedir. Orman ve mera kaplı yamaç arazilerde yer alan topraklarda SDA değerleri en yüksek değere sahiptir.

\section{Teșekkür}

Bu çalıșma 2130073 kodlu TUBITAK TOVAG tarafindan desteklenmiștir. Desteklerinden dolayı teșekkür ederiz.

\section{KAYNAKLAR}

Akalan i (1969). Kuzey- Batı Cukurova topraklarında organik madde miktarı ile suya dayanıkı agregatlar arasındaki ilișki. Ankara Üniversitesi Ziraat Fakültesi Yıllığı, Fasikül: 1-2, 170-227s.

Akkan E (1970). Bafra burnu-delice kavșağı arasında kızılırmak vadisinin jeomorfolojisi. Ankara: Ankara Üniversitesi Dil ve Tarih-Coğrafya Fakültesi Yayını.

Aksoy $N$ (1973). Mikroorganizmalarla așılama ve fumigasyonun muhtelif rutubet seviyelerinde inkübasyona tabi tutulan bazı Doğu Karadeniz, Doğu Anadolu ve Güneydoğu Anadolu topraklarının agregatlașmalarına olan etkileri. Atatürk Üniversitesi Ziraat Fakültesi Yayınları No. 93.
Bouyoucous G J (1951). A recalibration of hydrometer for making mechanical analysis of soils. Agronomy Journal, 43(9), 434-443

Gedik A, Korkmaz S (1984). Sinop havzasının jeolojisi ve petrol olanakları. Jeoloji Mühendisliği, 19, 53-79.

Chester G, Attoe O J, Allen O N (1957). Soil aggregation in relation to soil constituents. Soil Science Society America Proceedings, 21: 272-277.

Jackson M L (1958). Soil chemical analysis. Englewood cliffs, New Jersey: Prentice Hall Inc.

Jenny H (1941). Factors of soil formation. Mc Graw-Hill, New York, pp.281.

Kemper W D, Rosenau R C (1986). Aggregate stability and size distribution, in Klute, A. (ed.): Methods of Soil Analysis: Part I. 2nd edn., ASA, Madison, WI, USA, pp. 425-442.

Oades J M (1984). Soil organic mater and structure stability, mechanisms and implication for measurement. Plan and Soil , 76: 319-337.

Özbek H, Kaya Z, Gök M, Kaptan H (1993). Toprak bilimi kitabı. Çukurova Üniversitesi Ziraat Fakültesi, Yayın no: 73, Ders Kitapları Yayın no: A-16, ss: 77-119, Adana.

Öztürkmen A R, Savaș Y (2014). Harran ovasındaki bazı toprak serilerinin sulama sonrası agregat stabilitesinin değișimi. Harran Tarım ve Gıda Bilimleri Dergisi 18 (2), 8-14.

Rhoades J D (1986). Cation exchange capacity. Chemical and microbiological properties. In: Methods of Soil Analysis, Part II, 2nd Ed. ASA and SSSA Agronomy Monograph, No 9, Madison, Wisconsin.

Rost C O, Rowles C A (1940). A study of factors affecting the stability of soil aggregates. Soil Science Society America Proceedings, 5: 421-433.

Soil Survey Staff (1992). Procedures for collecting soil samples and methods of analysis for soil survey. Soil Surv. Invest. Report, Washington D.C., USA: I. U.S. Gov. Print. Office.

Soil Survey Staff (1993). Soil survey manual, USDA Handbook, Washington D.C., No: 18.

Soil Survey Staff (1999). Soil taxonomy. A basic of soil classification for making and interpreting soil survey. USDA Handbook, Washington D.C., No: 436.

Soil Survey Staff (2004). Soil survey laboratory methods manual soil survey investigations report, USDA, No:42.

Tanju Ö (1996). Toprak genesisi ve sınıflandırma. Ankara Üniversitesi Ziraat Fakültesi Yayın No: 1472, 437.

Thornthwaite C W (1948). An approach toward a rational classification of climate, Geographical Review, vol. 38, pp. 55-94.

Yao X, Xu X, Yu D (1990). Formation of structure in red soils in the different forms of utilization (in Chinese with English abstract). Acta Pedol. Sin. 27: 25-33. 


\title{
Eskișehir îli Meralarının Azotlu ve Fosforlu Gübre Gereksinimlerinin Belirlenmesi
}

\author{
Celalettin AYGÜN', İsmail KARA', A. Levent SEVER', İlker ERDOĞDU', A. Kadir ATALAY', \\ K. Aytaç ÖZAYDIN², Hakan YILDIZ², Öztekin URLA², Metin AYDOĞDU², Ediz ÜNAL², \\ Osman AYDOĞMUȘ², Fatma DEDEOĞLU², M. Güven TUĞAÇ², Harun TORUNLAR², \\ Hicrettin CEBEL ${ }^{3}$, Oğuz BAȘKAN³ ${ }^{3}$ Mehmet KEÇECl ${ }^{3}$, Mustafa BOZKURT ${ }^{3}$ \\ 'Geçit Kușağı Tarımsal Araștırma Enstitüsü Çayır Mera Yem Bitkileri Bölümü, ESKiȘEHİR \\ ${ }^{2}$ Tarla Bitkileri Merkez Araștırma Enstitüsü, Coğrafi Bilgi Sistemleri Bölümü, ANKARA \\ ${ }^{3}$ Toprak Gübre ve Su Kaynakları Merkez Araștırma Enstitüsü, ANKARA
}

Sorumlu yazar e-posta (Corresponding author e-mail): Celalettin.aygun@tarim.gov.tr

Geliș tarihi (Received) : 17.03.2015

Kabul tarihi (Accepted): 09.03.2017

\section{Öz}

Bu çalıșmada Türkiye Bilimsel ve Teknolojik Araștırma Kurumu (TÜBITAK) tarafından desteklenen "Ulusal Mera Kullanım ve Yönetim Projesi" kapsamında ülkemiz genelinde 48 ilde yürütülen çalıșmanın Eskișehir ili meralarında 142 alandan 0-25 cm derinlikten alınan toprak örneklerinin fiziksel ve kimyasal analizleri sonucunda meraların azot $(\mathrm{N})$ ve fosfor $\left(\mathrm{P}_{2} \mathrm{O}_{5}\right)$ gübre gereksinimleri tespit edilmiștir.

Eskișehir meralarının durum sınıfları sırasıyla; zayıf, orta, iyi; 52 (\%36.6), 88 (\%62), 2 (\%1.4), sağlık sınıfı olarak sırasıyla; riskli, sağlıklı, sorunlu; 13 (\%9.2), 123 (\%86.6), 6 (\%4,2), ve ıslah durumu sırasıyla; Öncelikle ıslah edilmeli, ıslahta fayda var, doğru yönetim; 64 (\%45.1), 76 (\%53.5), 2 (\%1.4) olarak belirlenmiștir.

Buna göre verilmesi gereken saf fosfor $\left(\mathrm{P}_{2} \mathrm{O}_{5}\right) ; 19$ merada yeterli, 3 merada 0.06-0.50 kg da-1, 9 alanda $1.0-1.90 \mathrm{~kg} \mathrm{da}^{-1}, 12$ merada $2.0-2.78 \mathrm{~kg} \mathrm{da}^{-1}, 18$ alanda $3.06-3.97 \mathrm{~kg} \mathrm{da}^{-1}$ arasında, 22 merada 4.11-4.99 kg da-1, 22 merada 5.08-5.99 kg da-1 22 merada 6.16-6.95 kg da-1 arasında, 8 merada 7.16$7.82 \mathrm{~kg} \mathrm{da}^{-1}$ arasında, 7 alanda ise $8.04-9.80 \mathrm{~kg} \mathrm{da}^{-1}$ intiyaç olduğu, azot olarak verilmesi gereken saf azot(N) ise; 9 merada $2.3-2.9 \mathrm{~kg} \mathrm{da}{ }^{-1}, 24$ merada 3.0-3.9 kg da-1, 33 merada $4.0-4.9 \mathrm{~kg} \mathrm{da}^{-1}$ arasında, 40 merada $5.0-5.9 \mathrm{~kg} \mathrm{da}^{-1}$ ve 37 merada $6.0-7.0 \mathrm{~kg} \mathrm{da}^{-1}$ olarak belirlenmiștir.

Anahtar Kelimeler: azot, fosfor, mera, toprak, verim

\section{Determination of Nitrogen and Phosphorus Fertilizer Requirements For Eskișehir Province Grasslands}

\section{Abstract}

The objective of this study is to determine soil physical and chemical characteristics of rangelands of Eskișehir province and to determine nitrogen $(N)$ and phosphorus $\left(P_{2} O_{5}\right)$ fertilizer requirements of those rangelands. Soil sampling was carried out on 142 locations, from 0 to $25 \mathrm{~cm}$ depth, distributed over grasslands of Eskișehir. According to study results; Condition classes of Eskișehir grasslands is as follows; rangelands of 52 sampling point (\%36.6) is in poor condition, 88 sampling points (\%62.2) is medium, and 2 sampling points (\%36.6) good, Health classes of those rangelands are risky, healthy, and problematic in 13 (\%9.2), 123 (\%86.6), and 6 (\%6.2), sampling points respectively. Rehabilitation is necessary in grasslands of 64 sampling points (\%45.1), the rehabilitation is helpful in 76 points(\%53.5) and only soil management practices is necessary in 2 points (\%1.4). 
According to study results fertilizer need of the grasslands is as follow; no phosphorus application is necessary for 19 grasslands sites, For the other sites, phosphorus (P2O5) requrements are calculated as; $0.06-0.50 \mathrm{~kg} \mathrm{da}^{-1}$ for 3 sites, $1.0-1.90 \mathrm{~kg} \mathrm{da}^{-1}$ for 9 sites, $2.0-2.78 \mathrm{~kg} \mathrm{da}^{-1}$ for 12 sites, $3.06-3.97 \mathrm{~kg}$ $\mathrm{da}^{-1}$ for 18 sites, $4.11-4.99 \mathrm{~kg} \mathrm{da}^{-1}$ for 22 grasslands sites, $5.08-5.99 \mathrm{~kg} \mathrm{da}^{-1}$ in 22 sites, $6.16-6.95 \mathrm{~kg}$ $\mathrm{da}^{-1}$ in 22 sites, $7.16-7.82 \mathrm{~kg} \mathrm{da}^{-1}$ in 8 sites, $8.04-9.80 \mathrm{~kg} \mathrm{da}^{-1}$ in 7 sites. The amount of nitrogen deficit in sites are as follows; $2.3-2.9 \mathrm{~kg} \mathrm{da}^{-1}$ in 9 sites, $3.0-3.9 \mathrm{~kg} \mathrm{da}^{-1}$ in 24 sites, $4.0-4.9 \mathrm{~kg} \mathrm{da}^{-1}$ in 33 sites $5.0-5.9 \mathrm{~kg} \mathrm{da}^{-1}$ in 40 sites and $6.0-7.0 \mathrm{~kg} \mathrm{da}^{-1}$ in 37 sites.

Keywords: grassland, nitrogen, phosphorous, soil, yield

\section{Giriș}

Yoğun, yüksek verimli tarım, özellikle endüstriyel olarak üretilen $\mathrm{NH}_{4}$ ve $\mathrm{NO}_{3}$ olmak üzere gübrelerin kullanılmasına bağlıdır. Dünyanın bazı bölgelerinde, gübrelerin az miktarda uygulanmasıyla mahsul üretiminin sınırlı olduğu (Pinstrup vd., 1996). Sentetik gübrelerin kullanılmaması halinde, dünya gıda üretimi o oranda artmıș olamazdıve daha doğal ekosistemler tarıma dönüștürülmüș olurdu. 1960 ile 1995 yılları arasında küresel olarak azot gübresi kullanımı yedi kat ve fosfor kullanımı 3.5 kat artmıștır (Tilman vd., 2001; Cassman ve Pingali, 1995). Benzer șekilde, fosforlu gübreler küresel olarak yıllık karasal fosfor mobilizasyonunun iki katına çıkmasına katkıda bulunmuștur (Carpenter vd., 1998).

Tarımsal faaliyetlerde amaç sürdürülebilir uygulamalarla yüksek ve kaliteli verim elde etmek olup, bu amaçla çevreye zarar vermeden az girdi ile üretim yapmanın yollarından birisi de yetiștirilen ürünün isteği doğrultusunda gübre uygulamasıdır. Sürekli kullanılmak suretiyle besin madde güçleri azalan toprakların gübreleme ile beslenerek verimli hale getirilmeleri teknik bir uygulamadır. İçerisinde bir veya birkaç besin maddesi bulunduran bileșiklerden en fazla azot, fosfor ve potasyum kimyevi gübre olarak kullanılmaktadır.

Ülkemiz mera alanları $13,162,577$ ha çayır alanları, 1,449,343 ha toplam çayır mera alanı ise 14,611,920 ha olup, İç Anadolu bölgesi 4,337, 493 ha ile en geniș mera alanına sahip ikinci bölgedir. Eskișehir ili mera alanları ise 325,851 ha'dır (Anonim, 2012; Mermer vd., 2012).

Eskișehir ili meralarının vejetasyon etüdü neticesinde çok iyi mera tespit edilememiș, 2 meranın iyi, 88 meranın orta ve 52 meranın zayıf mera durumuna sahip olduğu, mera sağığı açısından ise 13 meranın riskli, 123 meranın sağlıklı, 6 meranın sorunlu sınıfında yer aldığı, 2 meranın doğru yönetilmesi, 76 meranın ıslahında fayda bulunduğu ve 64 meranın ise öncelikle Islah edilmesi gerektiği belirlenmiștir (Aygün vd., 2010a, b).

Eskișehir meralarında 275 farklı tür tespit edilmiș, 33 adedinin buğdaygil, 39 adedinin baklagil ve 202 adedinin diğer familyalara ait türler olduğu, kalite dereceleri açısından 21 adedinin azalıcı, 20 adedinin çoğalıcı ve 233 adedinin istilacı türlerden olușmuștur (Aygün vd., 2011, 2013b).

Kaba yemler, hayvancilık için en ucuz yem kaynağı olup gübreleme ile arttırılabilirler. N topraktaki en yetersiz besleyici element olup, genellikle yem üretiminde en büyük etkiye sahiptir (Malhi vd., 2004). Fakat P bazı topraklarda sınırlıda olsa bulunmaktadır (Sedivec ve Manske, 1990; Berg ve Sims, 1995).

Organik madde, toprakta besin maddelerinin depolanmasına, toprak ișlenmesinin kolaylașmasına, su ve havanın hareketine, suyun tutulmasına ve kullanılmasına, erodibilite, insektisitlerin etkinliliğine ve dekompozisyonunu sağlar (Gregorich vd., 1994). Dolayısıyla, toprak kalitesi ve tarımsal üretimin sürdürülmesi için yeterli toprak organik madde seviyesinin korunması zorunludur.

Yemler, çok yönlü ve geniș kök sistemleri nedeniyle toprak organik maddelerini arttırmak için kullanılabilir, baklagiller ise rizobium bakterileri ile toprağa azot fiksasyonu sağlarlar (Guretzky vd., 2004). Yapılan çalıșmalarda birkaç yıl gübre kullanımının toprak organik maddesini arttırdığını bildirmișlerdir (Malhi ve Nyborg (1999). Bazı SIVI gübre uygulamaları ile verimin arttığı, bunun yanında toprakta organik C oranının da arttığı bildirilmiștir (King, 2002). 
Yemlerdeki Azot konsantrasyonu N alımı ve oranına bağı olarak artar (Malhi vd., 1986; Ukrainetz ve Campbell, 1988). Gübrelerin yem kuru madde verimi (DMY) ve ekonomik getiri artıșındaki etkinliği, topraktaki besin düzeylerine, nem koșullarına, kaynağa, gübre uygulama oranı ve yöntemine, toprak tipi ve bitki türlerine bağlıdır. Yem üretiminin miktarı ve kalitesi, hayvan performansı üzerinde doğrudan etkilere sahip olabilir. Mera ve çayırlarda gübre uygulamaları, gübrelenmeyen alanlara kıyasla hayvanlarda günlük verim artıșı ve meranın tașıma kapasitesinde önemli artıșlara neden olmuștur (Agriculture ve Agri-Food Canada, 1993).

Bu çalıșmada amaç, gübreleme ile mera veriminin arttırımasına, meranın kendi kendine yeter hale getirilmesine ve otlatma sezonunun uzatılmasına yardımcı olmak üzere mera üzerinde faaliyet gösteren mera yönetimi uzmanlarına, mera yönetim birliklerine bilgi üreterek yardımcı olmaktır.

\section{Materyal ve Yöntem}

Çalıșma noktaları GPS ile belirlenerek kaydedilmiș, 0-25 cm'den alınan 142 adet toprak örneği kurutularak, 2 mm'lik eleklerden geçirildikten sonra analizler için hazır hale getirilmiș ve Ankara Toprak, Gübre ve Su Kaynakları Merkez Araștırma Enstitüsü Müdürlüğü laboratuarlarında fiziksel ve kimyasal analizlere tabii tutulmuștur.

Örneklerin fiziksel analizleri bünye (Bouyoucos, 1951), hidrolik iletkenlik Klute ve Dirksen (1986), hacim ağırlığı Blake ve Hartge (1986), nem karakteristik değerleri tarla kapasitesi ve sürekli solma noktası değerleri (Anonim, 1954), toprak erodibilite (K) faktörünün saptanması Wischmeier ve Smith (1978) göre yapılmıștır.

Kimyasal analizlerden suyla doygunluk (\%) Richards (1954), toprak reaksiyonu (pH) Richards (1954) toplam tuz (\%) (Soil Survey Staff 1951), kireç (\%) Çağlar (1949), organik madde (\%) Ülgen ve Ateșalp (1972) tarafından bildirildiği șekilde modifiye Walkley- Black 'a göre, yarayıșlı potasyum (kg P2O5 da-1) Richards (1954), yarayıș Iı fosfor (kg P2O5 da') Olsen (1954), yöntemleri ile saptanmıștır.

Örneklerin bünye sınıfları, pH değerleri, toplam tuz, kireç içerikleri, organik madde içerikleri sınır değerleri, fosfor ve potasyum miktarları Ülgen ve Yurtsever (1995) tarafından bildirilen sınır değerlerine göre sınıflandırılmıștır.
Bu çalıșmada amaç Eskișehir ili mera alanları için gübre tavsiyesinde bulunarak, gübrelemeden beklenen faydaları elde ederek bu doğal alanlardan azami verim elde etmek olmustur.

\section{Sonuçlar ve Tartıșma}

Gübreler, tarımsal üretim sonucu topraktan eksilen bitki besin maddelerini tekrar toprağa kazandıran ve toprağın verim gücünü artıran maddeler olup, bunun yanı sıra gıda kalitesini de yükseltmenin en etkin araçlarındandır. Diğer tarımsal girdilerle karșılaștırıldığında gübreler, tek basına \%40'ın üzerinde verim artısı sağlamaktadır (Eraslan vd., 2009). Günümüzde uygulanan azotlu gübrenin sadece\% 30-50'sinde (Smil, 1999a, 2000b) ve fosfor gübresinin\% 45'i bitkiler tarafından tüketilmektedir.

Azot gübrelemesi ile doğal mera veriminde gözle görülür artıșlar birkaç araștırmacı tarafından bildirilmiștir (Rogler ve Russell, 1957; Wayne ve Elder, 1960; Badam, 1965; Cosper vd., 1967; Lardner, 1998). Doğal merada bitkilerin gübrelemeye verdikleri respons uygulama alanının konumundan kaynaklandığı vurgulanmıștır (Frank vd., 1968).

Dünya hayvancilık üretim sistemleri karıșık, topraksız ve pastoral sistemler olarak sınıflandırılabilir. Üretim sistemleri karıșık ve topraksız sistemler, konsantreler ve kuru ot, yem bitkileri, mahsul artıkları ve diğer yem hammaddelerinden olușan bir kaba yoğușmaya dayanan yüksek girișli sistemlerdir. Pastoral sistemler neredeyse tamamen otlatma ve sentetik gübreler gibi düșük dıș girdilere dayanan düșük girișli sistemlerdir (Bouwman vd.,2005).

Meraların gübrelenmesi ekilebilen alanların gübrelenmesinden daha komplekstir. Ancak ana ilkeleri ve prensipleri iyi olușturulmuștur. Azot, bitkilerin gelișiminde çok büyük bir etkiye sahip olsa da, hedef kuru madde verimi, yeterli nem temini (yağıș veya depolanmıș toprak nemi), yeterli sıcaklık, diğer bitki besinlerinin dengeli beslenmesi, tatmin edici toprak $\mathrm{pH}$ ve tatmin edici ot kompozisyonu gibi diğer șartlara uyulması durumunda elde edilir (Anonim, 2011).

Bașarılı gübre seçimi ve uygulama için, toprak endeksinin iyi bilinmesi, toprak içeriğinin, özellikle $\mathrm{N}, \mathrm{P}, \mathrm{K}$ ve $\mathrm{S}$ en uygun miktarlarının belirlenmesi gerekli olup; her yıl kullanılan alanın \% 25-30'luk kısmında örneklemeler yapılması, toprak pH'sının 
bilinmesi gibi bilgiler biçme-otlatma tepkisi açısından önemli olup; daimi meralarda ideal $\mathrm{pH}$ 6 olması gibi meraların temel bilgilerinin ve toprak türünün bilinmesi, eğer mümkünse geçmiș verim kayıtlarının tutulması gibi altı faktör anahtardır.

Çayır-mera verimini etkileyen diğer ürün yönetimi uygulamalarında ise toprak $\mathrm{pH}^{\prime} \operatorname{sın} ı n$ bilmek, toprak yapısını korumak ve toprağın sıkıșmasını minimize etmek, toprak drenajını arttıran bakım çalıșmalarını yapmak, besin değeri ve verimini maksimize etmek için meranın kaplıı̆ı içinde istenen türlerin yüksek oranda bulunması, düzenli tohumlama ve / veya mera üzerinden yüksek kaliteli bitkileri korumak, üstten tohumlama suretiyle ekim ve kalitenin yanı sıra verimli çeșitleri seçmek, etkili bir otlatma yönetimi uygulaması ile meranın zarar görmesini önleyerek verimi arttıracaktır (Anonim, 2014).

Mera verimini ve kalitesini artırmak amacıyla gübrelerin idaresi için bir takım agronomik stratejiler olup, en iyi sonuç verecek olan oran, form ve uygulama yönteminin seçimi önemlidir. Bitkinin büyümesi için topraktaki mevcut $N$ oranının ölçülmesi uygulanacak etkili gübre oranını belirlemede yararlı olacaktır (Collins ve Allinson, 2004).

Tarım topraklarının verimli olabilmesi ve verim güçlerinin korunabilmesi ancak çeșitli șekillerde kaybolan bitki besin maddelerinin, gübre uygulamaları sonucunda toprağa geri kazandırılması ile mümkündür. Gübrelerden en üst düzeyde fayda sağlanabilmesi için bitki istekleri, iklim, toprak yapısı, toprak $\mathrm{pH}^{\prime}$ sı ve vejetasyon dönemi dikkate alınarak doğru bitkide, doğru yerde, doğru zamanda, doğru gübrenin kullanılması gerekmektedir (Eraslan vd., 2009).

Ülkemiz topraklarının organik madde miktarının az olduğu, Eskișehir il geneli topraklarının organik madde miktarının ise çok az \%13.1, az \%38.7, orta \%32.8, iyi \%10.8 ve \% 4.6 yüksek olduğu bildirilmiștir (Eyüpoğlu, 1999). Eskișehir mera toprakları organik madde miktarının ise sırasıyla; çok az, az, orta, iyi, yüksek; $17(\% 12 ; 0.40-0.99)$, 55 (\%39; 1.18-1.96), 38(\%27; 2.01-2.77), 12(\%8; 3.01-3.54), 20(\%14; 4.16-27.40) olduğu bildirilmiștir (Aygün vd, 2013a). Toprak organik maddesinin tarım yapılan geniș alanlar içerisinde istikrarının birçok faktör tarafından etkilendiği ve karmașık etkileșimler halinde olduğu, organik maddenin iklim ve toprak yapısı arasındaki ilișkiler de yağıș ve kil içeriğine bağı olarak arttığı ve sıcaklığa bağlı olarak azaldığı bildirilmiștir (Burke, 1989).

Meralarda, toprakta rezerve azot miktarı belirgin olarak değișiklik göstermektedir. Önerilen azot değerleri, orta azotlu toprak azot tedarik durumuna karșilık gelir ve belirli bir alanda yüksek veya düșük toprak azot verilmesi için ayarlamalar yapılması gerekir. Yeni kurulan suni meralar haricinde, yoğun olarak idare edilen mera alanlarında yüksek toprak azotu statüsüne sahip olmasının, azot için daha düșük bir intiyaca neden olacağı așikârdır. Bunun nedeni ise; otlatma sırasında organik gübrelerden veya hayvan dıșkısı ile geri dönen azot sonucu toprak azotunun olușması, uzun ömürlü bitki örtüsünün, sızma suretiyle azot kaybını sınırlamasıdır.

Kuru madde verimini arttırmak için meralara gübreleme yapılması, botanik bileșimde baklagil oranlarının azalmasına neden olur Aydin ve Uzun (2005). Doğal meralarda fosforun yüksek veya orta düzeyde olması, arzu edilen türlerde simbiyotik bir ilișki içinde olan mikorizal mantarlarını azaltacak veya ortadan kaldıracaktır.

Badam (1965)'e göre; fosfor ve potasyum uygulamalarının verime etkisinin olmadığı, 60 $\mathrm{kg} \mathrm{da}^{-1}$ saf uygulamasının iki yıl boyunca verilen her gübreye karșllık hektara 1.08-1.29 oranında bir verim artıșı, 40-160 kg da-1 verim elde edildiği, yine fosfor ve potasyum uygulamalarında bitki kompozisyonunun etkilenmediği, Azot uygulamasının geniș yapraklı bitkilerin miktarının azalttığı, ancak verinde artıș sağladığı, buna ilaveten (Badam, 1965), kombine (N60P60K60) uygulamasının bitkilerdeki toplam protein miktarını \% 280-430 oranında arttırdığını bildirmiștir.

Jigjidsuren (1975), çevre ve gübreleme rejiminin etkilerinden dolayı çok yıllık bitkilerin biyolojik özelliklerinde meydana gelen değișiklikler ve Bromus inermus, Elymus sibirica Elymus dahurian ile 1:2 oranında yonca ekilmenin mera için daha faydalı olduğunu ve diğer karıșımlara kıyasla daha besleyici olduğu, Ayrıca, mineral gübrenin, özellikle azotun yonca otu üzerine uygulanmasının mera, verimi 590-750 kg ha arttırdığı bildirilmiștir.

Nyamdorj(1980) yaptığı çalıșmada uygulanan $\mathrm{N}$, NK ve NP karıșımlarının uygulamadan sonraki yıllarda verimi \% 20-30 arttırır iken yine uygulanan 
tekli ve kombine gübrelerin verimi \%50-60 arttırdığını bildirmiștir.

Gübrelerin yapısına bağlı olarak farklı uygulama yolları olup, katı gübrelerin yem bitkileri tarlalarına atılabileceği gibi bazı gübrelerde sıvılaștırılarak verilebilir. Yem bitkilerinde gübre besin maddelerini uygulama yolları vardır.

Formülasyona bağlı olarak granüler veya sıvı farklı yöntemler uygulanabilir: Tohum hazırlığı sırasına hem granüler hem de sıvı gübreler karıștırıla bilinir. Tesis öncesinde ya da ekim esnasında tohumdan yan bant ya da derin bant șeklinde toprağa karıștırılır. Bant șeklinde uygulamalar, N, P ve K gübrelerinin daha fazla kullanım verimliliğine neden olur (Tremblay ve Panchuk 2000).

Lkhagvasuren (2007)'e göre azot ve fosforun kullanımının yem miktarı, kalitesi ve toprak özelliklerine etkisi ile yüksek alanlarda ve meralarda gübrenin verime etkisini incelemiș olup, ilkbaharda azotun bant șeklinde verilmesi verimde önemli artıșlar sağlamıș olup, kuru madde verimi kontrol ile karșılaștırıldığında yaklașık 1.5-2.5 kat daha fazla verim artıșı sağladığı bildirilmiștir. Uygulamalar içerisinde $50 \mathrm{~kg} \mathrm{da}^{-1}$ uygulamanın etkili olduğu, en yüksek verim artıșı sağladığı, daha yüksek azot uygulama oranlarının ise ek protein konsantrasyonu ile sonuçlandığı bildirilmiștir. Uygulama mevsiminin sonbaharında ölçülen $N$ ve P gübre uygulamalarının bir bütün olarak toprak kimyasal ve fiziksel özellikleri üzerinde sınırlı bir etkisi olmuștur. Daha önceki çalıșmalarda göstermiștir ki azot verim sınırlayıc faktördür (Sedivec ve Manske 1990; Berg ve Sims, 1995; Malhi, vd., 2004). Bu çalıșmada yüzeye șerit bant vs enjekte edilmek suretiyle verilen fosfor gübresine karșilık herhangi bir cevap alınamamıștır.

Bitki dağılımını ve bolluğunu etkileyen en önemli faktörler sıcaklık, nem, besin elementi ve ıșıktır. Bunlar yağıș dağılımı, toprak ve yöney haritaları ile değerlendirilebilir. Bu katmanlar CBS ortamında birleștirilerek benzer çevre șartlarına sahip alanlar elde edilebilir (Neldner, 1995; Margules ve Redhead, 1995). Kuraklık indeksi, bakı ve rakım sayısal değerlerinin birleștirilmesi ile homojen ekolojik alanlar olușturulur. Eskișehir meralarının büyük çoğunluğu da toplam alanın \% 59.4'ünü olușturan 13 ve \% 33.8'ini olușturan 14 'nolu homojen alanda yer almaktadır. Bu alanlar benzer bitki topluluklarını içerirler.
Eskișehir meraları için azot hesaplamasında; Yarayıșlı Saf (N) Azot kg da-1 (maks. 8 kg) olması düșünüldüğünde yarayıșlı azot çarpanı (Sınıf Harita Kuraklık_index P/PET çarpanı + Organik Madde çarpanı + Mera Durum çarpanı) ortalaması, sonuçta verilmesi gereken saf (N) yarayıșlı azot kg $\mathrm{da}^{-1}$ belirlenmiștir.

Buna göre çalıșılan mera alanları için verilmesi gereken saf azot $(\mathrm{N})$ ise; 9 mera için $2.3-2.9 \mathrm{~kg}$ $\mathrm{da}^{-1}, 24$ mera için 3.0-3.9 kg da-1, 33 mera için $4.0-4.9 \mathrm{~kg} \mathrm{da}^{-1}$ arasında, 40 mera için 5.0-5.9 $\mathrm{kg} \mathrm{da}^{-1}$ ve 37 mera için ise $6.0-7.0 \mathrm{~kg} \mathrm{da}^{-1}$ olarak belirlenmiștir.

Durum azot (N) miktarı açısından, mera durum sınıfları dikkate alınarak hesaplandığında ise; iyi sınıf meralar için $4 \mathrm{~kg}$ Azot/da, orta sınıf meralar için 6 $\mathrm{kg} \mathrm{da}^{-1}$ azot ve zayıf sınıf meralar için ise $4 \mathrm{~kg}$ Azot/ da verilmesi hesaplanmıștır.

Fosfor birçok bitkinin metabolik süreçlerinin arkasındaki enerji ve enzim aktivitesinde önemli bir role sahip olan bitki büyüme ve gelișmesi için gerekli olan besin maddesidir. İyi bir gübreleme ile otlatma süresi uzar, yemin lezzetliliği, süt verimi ve kalitesi artar.

Fosfor hesaplamasında ise; Yarayıșlı fosforun $\mathrm{kg} \mathrm{da}^{-1}$ (maks. $12 \mathrm{~kg}$ ) olması düșünüldüğünde, yarayıșlı fosfor çarpanı (Su ile Doymușluk çarpanı + Kireç $\left(\mathrm{CaCO}_{3}\right)$ çarpanı + Yarayıșlı Fosfor $\left(\mathrm{P}_{2} \mathrm{O}_{5}\right)$ çarpanı + Organik Madde çarpanı + Mera Durum çarpanı) ortalaması sonucunda verilmesi gereken saf $\left(\mathrm{P}_{2} \mathrm{O}_{5}\right)$ yarayıșlı fosfor $\mathrm{kg}$ da-1 olarak belirlenmiștir.

Buna göre; verilmesi gereken saf fosfor $\left(\mathrm{P}_{2} \mathrm{O}_{5}\right)$ olarak; 19 merada yeterli olduğu, 3 merada $0.06-0.50 \mathrm{~kg} \mathrm{P} 2 \mathrm{O} 5 \mathrm{da}^{-1}$, 9 merada $1.0-1.90 \mathrm{~kg}$ P2O5 da-1, 12 merada 2.0-2.78 kg P2O5 da 1, 18 merada $3.06-3.97 \mathrm{~kg} \mathrm{P}_{2} \mathrm{O}_{5} \mathrm{da}^{-1}$ arasında, 22 merada 4.11-4.99 kg $\mathrm{P}_{2} \mathrm{O}_{5} \mathrm{da}^{-1}, 22$ merada $5.08-5.99 \mathrm{~kg} \mathrm{P} \mathrm{O}_{5}$ da-1, 22 merada $6.16-6.95 \mathrm{~kg}$ $\mathrm{P}_{2} \mathrm{O}_{5} \mathrm{da}^{-1}$ arasında, 8 merada $7.16-7.82 \mathrm{~kg} \mathrm{P}_{2} \mathrm{O}_{5}$ $\mathrm{da}^{-1}$ arasında, 7 alanda ise $8.04-9.80 \mathrm{~kg} \mathrm{P}_{2} \mathrm{O}_{5} \mathrm{da}^{-1}$ intiyaç olduğu, meraların, durum sınıfı üzerinden değerlendirildiğinde ise; iyi sınıf meralar için $5 \mathrm{~kg}$ $\mathrm{P}_{2} \mathrm{O}_{5} \mathrm{da}^{-1}$, orta sınıf meralar için $5 \mathrm{~kg} \mathrm{P}_{2} \mathrm{O}_{5} \mathrm{da}^{-1}$ ve zayıf sınıftaki meralar için ise; $3 \mathrm{~kg} \mathrm{P}_{2} \mathrm{O}_{5} \mathrm{da}^{-1}$ saf olarak verilmesi gerektiği hesaplanmıștır.

lyi meralarda gübreleme ile bir yandan verim arttırılırken diğer yandan da merayı uzun dönemde kendi kendine yeterli hale getirilmiș olacaktır. Orta meralarda ise azalıcı türlerin oranı arttııımıș, zayıf 
Çizelge 1. Eskișehir Ilii Mera Durum Sınıflarına Göre Önerilen Gübre Dozları

Table 1. Recommended fertilizer doses for grassland class in Eskișehir province

Verilmesi Gereken Saf Gübre Miktarı

$\left(\mathrm{kg} \mathrm{da}^{-1}\right)$
Mera Durum Sinıfı

\begin{tabular}{ccc}
\hline Iyi Mera & Orta Mera & Zayıf Mera \\
4 & 6 & 4 \\
5 & 5 & 3
\end{tabular}

Sonuç olarak, Çizelge 1.'de görüldüğü üzere durum azot $(\mathrm{N})$ açısından incelendiğinde; iyi meralar için $4 \mathrm{~kg} \mathrm{da}^{-1}$, orta meralar için $6 \mathrm{~kg} \mathrm{da}^{-1}$ ve zayıf meralar için $4 \mathrm{~kg} \mathrm{da} \mathrm{a}^{-1}$ önerilmekte olup, fosfor $\left(\mathrm{P}_{2} \mathrm{O}_{5}\right)$ olarak önerildiğinde ise; iyi ve orta meralar için $5 \mathrm{~kg} \mathrm{da}^{-1}$, zayıf meralar için $3 \mathrm{~kg} \mathrm{da}^{-1}$ fosforun uygulanabilir olacağı kanaati olușmuștur.

\section{Teșekkür}

Bu çalıșma TÜBITAK Ulusal Mera Kullanım ve Yönetim Projesi (Proje No106G017) kapsamında yapılmıștır. Desteklerinden dolayı TÜBiTAK'a teșekkürlerimizi sunarız.

\section{Kaynaklar}

Agriculture \& Agri-Food Canada.1993. Fertilizer management for forage crops in central Alberta. Technical Bulletin 1993-3E. Research Branch Agriculture Canada.

Altın M (1975). Erzurum Șartlarında Azot, Fosfor ve Potasyumlu Gübrelerin Tabii Çayır ve Meranın Ot Verimine, Otun Ham Proteinve Ham Kül Oranınave Bitki Kompozisyonuna Etkileri Üzerine Bir Araștırma. Atatürk Üniversitesi Araștırma Serisi No:95, Erzurum, $141 \mathrm{~s}$.

Altın M, Tuna C, Gür M (2010). Tekirdağ Taban ve Kıraç Meralarının Verim ve Botanik Kompozisyonuna Gübrelemenin Etkisi. Tekirdağ Ziraat Fakültesi Dergisi. 7(2).

Anonim (1951). U.S. Salinity Laboratory Staff. (Editor: L. A. Richards) Diagnosis and improvementof Saline and Alkali Soils. USDA Agriculture Handbook No. 60. U.S. Goverment Printing Office, Washington, 25 D.C. 166 p.

Anonim (2011).http://adlib.everysite.co.uk/adlib/defra/ content.aspx?id=2RRVTHNX T89E4NMD3N35AN- 2011

Anonim (2012). Tarımsal Yapı. T.C. Bașbakanlık Devlet istatistik Enstitüsü. http://www.tuik.gov.tr/

Anonim (2014). www.countrywidefarmers.co.uk/ wiseadvice.2014 (Erișim Tarihi: 02/05/2014)

Aydin I, Uzun F (2005). Nitrogen and phophorate fertilization of rangelands affects yield, forage quality and the botanical composition. Eur. J. Agron.23:8-14.

Aygün C, Kara İ, Sever AL, Erdoğdu I, Atalay AK, Avağ A, Mermer A, Özaydınlı KA, Yıldı H, Urla Ö, Aydoğdu M, Ünal $E$, Aydoğmus $O$, Dedeoğlu $F$, Tuğaç $M G$, Torunlar $H$, Cebel H, Baskan O, Keçeci M, Bozkurt M, Ocak A (2010a). 13 Nolu Homojen Alan İçerisinde Yer Alan Eskișehir İli Mera Topraklarında Bulunan Bitkilerinin Belirlenmesi. I.Ulusal Toprak Ve Su Kaynakları Kongresi. s 1010-1018, 2010. EKiȘEHIR. kat arttırdığı vurgulanmıștır. 
Aygün C, Kara I, Sever AL, Erdoğdu I, Atalay AK, Avağ A, Mermer A, Özaydınlı KA, Yıldız H, Urla Ö, Aydoğdu M, Ünal $E$, Aydoğmus $O$, Dedeoğlu $F$, Tuğaç MG, Torunlar H, Cebel H, Baskan O, Keçeci M, Bozkurt M, Ocak A (2010b). 14 Nolu Homojen Alan İçerisinde Yer Alan Eskișehir İli Mera Topraklarında Bulunan Bitkilerinin Belirlenmesi. I.Ulusal Toprak ve Su Kaynakları Kongresi. s. 956-962. 2010. EKișEHIR.

Aygün C, Kara I, Sever AL, Erdoğdu I, Atalay AK (2011). Kurak ve Yarı Kurak Mera Alanlarındaki İndikatör BitkilerEskișehir Örneği. Kurak ve Yarı Kurak Alan Yönetimi Çalıștayı. 5-8 Aralık 2011 .Ürgüp-Nevșehir

Aygün C, Kara İ, Sever AL, Erdoğdu İ, Atalay AK (2013b). Eskișehir Meralarının Biyolojik Çeșitliliğe Katkısı. III. Su ve Biyolojik Çeșitlilik Sempozyumu. 22-23 Mayıs 2013 Marmaris.

Aygün C, Kara I, Sever AL, Erdoğdu I, Atalay AK, Avağ A, Mermer A, Özaydınlı AK, Yıldı H, Urla Ö, Aydoğdu M, Ünal E, Aydoğmuș O, Dedeoğlu F, Tuğaç MG, Torunlar H, Cebel H, Bașkan O, Keçeci M, Depel G, Bozkurt M (2013a). Eskișehir ili Mera Topraklarının Bazı Fiziksel ve Kimyasal Özelliklerinin Belirlenmesi. 3. Ulusal Toprak ve Su Kaynakları Kongresi. s.193-200. 22-24 Ekim 2013. Tokat

Badam M (1965). Surface improvement of the mountainsteppe pastures of Mongolia. Ph. D. Dissertation. Leningrad. Russia. National Library of Mongolia.

Bouwman AF, Van der Hoek KW, Eickhout B, Soenario I 2005. Agric. Syst. 84, 121-153

Berg WA, Sims PL (1995). Nitrogen fertilizer use efficiency in steer gain on old world bluestem. J. Range Manage. 48: 465-470.

Blake GR, Hartge KH (1986). Bulk Density. pp. 363-375 In A. Klute, ed.,Methods of Soil Analysis, Part I. Physical and Mineralogical Methods: Agronomy Monograph No:9. 2nd ed. Am. Soc. Agron., Madison, WI.

Bouyoucos GJ (1951). A Recalibration Of The Hydrometer Method For Making Mechanical Analysis Of Soils. Agronomy Journal 43: 435-438.

Burke IC, Yonker C M, Patron WJ, Cole CV, Flach K, Schimel DS (1989). Texture, Climate, And Cultivation Effects On Soil Organic Matter Context İn U.S. Grassland Soils, Soil Sci Soc. A M. J. 53, 800-805

Büyükburç U, Șengül S, Tahtacıoğlu L (1987). Erzurum İli Doğal Meralarının ıslahı Olanaklarının Araștırıması. DATAEM Yıllık Calıșma Raporu 1987. Erzurum.

Carpenter, SR,.Caraco NF, Correll DL, Howarth FW, Sharpley AN, SmthVH (1998). Nonpoint pollution of surface waters with phosphorus and nitrogen. Ecol. Applic. 8, 559568 (1998).

Cassman, KG, Pingali PL (1995). Intensification of irrigated rice systems: learning from the past to meet future challenges. GeoJournal 35, 299-305 (1995).

Cosper HR, Thomas JR, AlsayeghAY (1967). Fertilization and its effect on range improvement in the Northern Great Plains. J. Range Manage.. 20:216-222.

Çağlar KÖ (1949). Toprak Bilgisi. A.Ü.Z.F.Yayınları. No:10

Eraslan F, İnal A, GüneșA, Erdal İ, CoșkanA (2009). Türkiye'de Kimyasal Gübre Üretim ve Tüketim Durumu, Sorunlar, Çözüm Önerileri ve Yenilikler. mww.zmo.org.tr. Yayınları
Eyüpoğlu F (1999). Türkiye Topraklarının Verimlilik Durumu. Köy Hizmetleri Genel Müdürlüğü, Toprak ve Gübre Araștırma Enstitüsü Yayınları Ankara.

Gebhart DL, Johnson HB, Mayeux HS, Polley HW (1995). The CRP increases soil organic carbon. J. Soil Water Conserv. 49: 488-492.

Gregorich EG, Carter MR, Angers DA, Monreal CM, Ellert BH (1994). Towards a minimum data set to assess soil organic matter quality in agricultural soils. Can. J. Soil Sci. 74: 367-385.

Guretzky, J.A., K.J. Moore, A.D. Knapp, and C.E. Brummer. 2004. Emergence and survival of legume seeded into pasture varying in landscape position. Crop Sci. 44: 227233.

Hatipoğlu R (2016). Türkiyede Çayır Mera ve Yem Bitkileri Üretiminin Durumu, Sorunları ve Çözüm Yolları Çalıștayı. w20-21 Ekim 2016 Basılmamıș Sonuç Raporu. Yozgat

Jigjidsuren, S. (1975). Methods of improvement of the mountain-steppe pastures in central Mongolia. Ph. D. Dessertation. Leningrad. Russia. National Library of Mongolia.

King TN (2002). Liquid swine manure application to forage soils: Effect on Soil Carbon and Economic Returns M. Agr. Thesis. University of Saskatchewan. Department of Soil Science.

Klute A, Dirksen C (1986). Hydraulic Conductivity And Diffusivity, Laboratory Methods. P. 687-732. In A. Klute (Ed.) Methods Of Soil Analysis. Part 1. SSSA, Madison, WI.

Lardner HA 1998. Rejuvenation of Tame Forages. Ph. D. Thesis. Department of Animal and Poultry Science. University of Saskatchewan. Saskatoon.

Lkhagvasuren (2007). Plant and Soil Responses to Fertilization of Grasslands in Saskatchewan, Canada and Selenge, Mongolia. Head of the Department of Soil Science University of Saskatchewan 51 Campus Drive Saskatoon, Saskatchewan, Canada S7N 5A8

Malhi SS, McBeath DK, Baron VS (1986). Effect of nitrogen application on yield and quality of bromegrass hay in central Alberta. Can. J. Plant Sci. 66: 609-616.

Malhi SS, Gill KS, McCartney DH, Malmgren R (2004). Fertilizer management of forage crops in the Canadian Great Plains. Rec. Res. Develop. Crop Sci. 1: 237-271.

Malhi, SS, Nyborg M, Harapiak JT (1998). Effects of long-term $\mathrm{N}$ fertilizerinducedacidification and liming on micronutrients in soil and in bromegrass hay. Soil Tillage Res. 48: $91-101$.

Manga I, Altın M, Gökkuș A (1986). Erzurum Doğal Meralarında uzun Yıllar Gübrelemenin Verim, Vejetasyon ve Toprağın Bazı Özelliklerine Etkileri Üzerinde Bir Araștırma. Doğa Dergisi.

Margules CR, Redhead TD (1995). Guidelines for using the BioRap methodology and tools. In Series: BioRap, rapid assessment of biodiversity priority areas. CSIRO, Australia.

Mensah FK, Schoenau JJ, Malhi SS (2003). Soil Carbon changes in cultivated and excavated land converted to grass in east-central Saskatchewan. Biogeochemistry 63: 85-92. 
Mermer A, Ünal E, Aydoğdu M, Urla Ö, Yıldız H, Torunlar H, Avağ A, Tuğaç MG, Özaydınlı KA, Dedeoğlu F, Aydoğmuș O (2012). Tarım Bilimleri Araștırma Dergisi 5 (2): 107-110, 2012 ISSN: 1308-3945, E-ISSN: 1308-027X, www.nobel. gen.tr

Neldner VJ, Clarkson JR (1995). Vegetation Survey and Mapping of Cape York Peninsula. Cape York Peninsula Land Use Strategy, Office of the Co-ordinator General and Queensland Department of Environment and Heritage, Brisbane, Australia.

Nyamdorj J (1980). Ecological and biocenologycal effect of fertilization on hay field and pasture in northeast Hangai of Mongoilia. Ph.D dissertation. Ulaanbaatar. National Library of Mongolia.

Olsen SR, Cole CV, Watanabe FS, Dean LA (1954). Estimation of available Phosphorus in soil by extraction with sodium bicarbonate. U. S. Dept. of Agri. Circ. 939. Washington.

Pinstrup-AP, Pandya LR (1996). Food for all in 2020can the world be fed without damaging the environment. Environ. Conserv. 23, 226-234 (1996).

Richards LA (1954). Diagnosis and improvement of saline and alkali soils. U.S.D.A. Handb. 60. 101-102 (USA).

Rogler GA Russell JL (1957). Nitrogen fertilization of northern Great Plains rangelands. J. Range Manage. 10: 145-160.

Sedivec KK, Manske LL (1990). Renovation of rangeland and grassland pastures. N.D.S.U. Ext. Serv. Publ. Fargo N.D. Vol. 14: 6 .

Sedivec KK, Manske LL (1990). Renovation of rangeland and grassland pastures. N.D.S.U. Ext. Serv. Publ. Fargo N.D. Vol. 14: 6 .

Smil V (1999). Nitrogen in crop production: an account of global flows. Global Biogeochem. Cycl. 13, 647-662 (1999)

Smil V (2000). Phosphorus in the environment: natural flows and human interferences. Annu. Rev. Energy Environ. 25, 53-88 (2000).

Smith SD, Huxman TE, Zitzer SF, Charlet TN, Housman DC, Coleman JS, Fenstermaker LK, Seemann JR, Nowak RS (2000). Elevated CO2 80 increases productivity and invasive species success in an arid ecosystem. Nature 408: 79-82.
Tilman, D, Joseph F, Brian W, Carla D'A, Andrew D, Robert H, David S, William H. S, Daniel S, Deborah S (2001). Forecasting agriculturally driven global environmental change. Science 292, 281-284

Tremblay M, Panchuk K (2000). Fertilizing Forage, Agriculture, Food and Rural Revitalization publications.

Ukrainetz $\mathrm{H}$, Campbell CA, Zentner RP, Monreal M (1988). Response of bromegrass to N, P and S fertilizer on a gray luvisolic soil in northwest Saskatchewan. Can. J. Plant Sci. 68: 687-703.

Uslu ÖS (2005). Kahramanmaraș ilii Türkoğlu İlçesi Araplar Köyü Yenyapan Merasında Botanik Kompozisyonun Tespiti Ve Farkı Gübre Uygulamalarının Meranın Verimi Ve Botanik Kompozisyonuna Etkileri Üzerinde Araștırmalar. Tarla Bitkileri Anabilim Dalı. Doktora Tezi. s. 162. Adana, 2005.

Ülgen N, Yurtsever N (1995). Türkiye Gübre ve Gübreleme Rehberi, Köy Hizmetleri Genel Müdürlüğü, Toprak ve Gübre Araștırma Enstitüsü Müdürlüğü Yayınları, Genel Yayın No: 209, Teknik Yayınlar No:66, 4. Baskı, Ankara.

ÜIgen N, Atesalp M (1972). Toprakta Bitki Tarafından Alınabilir Fosfor Tayini. Köy İșleri Bakanlığı. Toprak su Genel Müdürlüğü. Toprak Ve Gübre Araștırma Enstitüsü. Teknik Yayınlar Serisi. Sayı 21. Ankara. $17 \mathrm{~S}$.

Wayne HW, Elder WC (1960). Effect of fertilizers on native grass pastures in Oklahoma. J. Range Manage. 13: 34-36.

Wischmeier WH, Smith DD (1978). Predicting rainfallerosion losses-A guide to conservation planning Agriculture Handbook No. 537, U. S. Dept. of Agric, Washington DC (1978), p. 58

Yavuz R, Karagül R (2014). Meranın Otlatma Kapasitesi Ve Botanik Kompozisyonuna Bazı Islah Yöntemlerinin Etkisi. Toprak Su Dergisi, 2014,3(1):6-11).

Yavuz T, Büyükburç U, Karadağ Y (2008). Gübreleme ve Dinlendirme ile Yapay Mera Tesisi Yöntemlerinin Doğal Meraların Verim ve Kalitesi Üzerine Etkileri. Tarım Bilimleri Araștırma Dergisil (1): 37-42, 2008 ISSN: 1308-3945, www. Nobel.gen.tr. 


\title{
Doğu Akdeniz Bölgesindeki Krom Maden Alanı Topraklarında Azot Mineralizasyonu
}

\author{
Nacide KIZILDAĞ * \\ Çukurova Üniversitesi, Merkezi Araștırma Laboratuvarı, 01330, Adana
}

*Sorumlu yazar e-posta (Corresponding author e-mail) : nkizildag@cu.edu.tr

Geliș tarihi (Received) : 17.01.2017

Kabul tarihi (Accepted): 20.03.2017

\section{Öz}

Kromun ( $\mathrm{Cr}$ ) endüstrideki yaygın kullanımına bağlı olarak çeșitli çevresel ortamlarda ciddi bir kirletici haline geldiği ve toprak mikroorganizmalarına karșı son derece toksik etki gösterdiği bilinmektedir. Buna göre kroma uzun süre maruz kalmıș ekosistemlerde toprak mikroorganizmalarının fonksiyonlarının bilinmesi çok önemli bir yer tutmaktadır. Bu bağlamda Aladağ' da (Adana) krom maden ocağına yakın ve ocaktan etkilenmemiș 3 farklı alandan (Bozluk, Kızılyüksek ve Yanıkçam) alınan cevherli ve cevhersiz toprakların azot mineralizasyonlarını kıyaslamak ve kromun mikroorganizmalara olası etkilerini ortaya koymak amaçlanmıștır. Toprakların azot mineralizasyonu $\left(\mathrm{NH}_{4}+-\mathrm{N}, \mathrm{NO}_{3}-\mathrm{N}\right)$ Parnas-Wagner metodu ile 42 gün boyunca (11., 26. ve 42. gün) $28^{\circ} \mathrm{C}$ ve sabit nemde belirlenmiștir. Yanıkçam lokasyonu haricinde cevherli toprakların toplam $\mathrm{Cr}$ içeriği cevhersiz topraklara göre daha yüksek bulunmuștur (309, $59 \mathrm{mg} \mathrm{kg}^{-1}$ ). Her üç lokasyonda da $\mathrm{Cr}$ ilave edilen ve edilmeyen cevhersiz toprakların azot mineralizasyon oranları, cevherli topraklardan daha yüksek bulunmuștur. En yüksek mineralleșme oranı $\mathrm{Cr}$ ilave edilmeyen cevhersiz Kızılyüksek toprağında (\% 1.73), en düșük ise yine $\mathrm{Cr}$ ilavesi olmayan cevherli Yanıkçam (\% 0.36) toprağında gözlenmiștir. Bu çalıșmadan elde edilen sonuçlara dayanarak, amonyak ve nitrat bakterilerinin kromdan etkilendiğini söylemek mümkündür.

Anahtar Kelimeler: Krom, azot mineralizasyonu, maden ocağı, toksisite, Aladağ

\section{Nitrogen Mineralization in Soils of Chromium Mine Area in the East Mediterranean Region}

\footnotetext{
Abstract

It is known that chromium became a serious pollutant in various environmental due to its common use in industry and that it is highly toxic effect for soil microorganisms. For this reason, it is important to know the functioning of soil microorganism in ecosystesms which are exposed to chromium for a long time. In this context, it was aimed to compare nitrogen mineralization of contamined and uncontamined soils which were in 3 different regions (Bozluk, Kızllyüksek and Yanıkçam) in Aladağ (Adana) near mine but not effected of it and to reveal possible effects of chromium on microorganism. Nitrogen mineralization of soils $\left(\mathrm{NH}_{4}+-\mathrm{N}_{1} \mathrm{NO}_{3}-\mathrm{N}\right)$ was determined by the Parnas-Wagner method over 42 days $\left(11^{\text {th }}, 26^{\text {th }}\right.$, and $42^{\text {nd }}$ days $)$ at $28^{\circ} \mathrm{C}$ and under constant moisture. The total $\mathrm{Cr}$ content of contamined soils is higher than uncontamined soils except for Yanıkçam region $1309,59 \mathrm{mg} \mathrm{kg}$ '). In each place, mineralization rates of chromium added contamined or uncontamined soils were measured higher than the soils which were contamined. The maximum mineralization rate was observed in uncontamined soils of Kızlyüksek (1.73\%) which were not added $\mathrm{Cr}$, the minimum rate was in the soils of contamined soils of Yanıkçam which were also not added $(0.36 \%)$. Based on the results obtained from the findings of this study, it is possible that ammonium and nitrate bacteria was affected by chromium.
} 
Key Words: Chromium, nitrogen mineralization, Mining, toxicity, Aladağ

\section{Gíriș}

Antropojenik faaliyetler sonucu toprakların ağır metallerce kirlenmesi tüm dünyada ciddi bir çevresel sorun haline gelmiștir. Madencilik, metalli cevherlerin, hurda metallerin eritilmesi ve ișlenmesi, kentsel atıklar, hem biosit (pestisit), hem de gübre uygulamaları ağır metallere bağlı toprak kirliliğinin ana kaynağını olușturmaktadırlar (Kebir ve Bouhadjera, 2011 ). Toprak mikrobiyal populasyonu bu ağır metallerden kaynaklanan büyük bir baskı altında olup (Chaudhary ve ark., 1996; Obbard, 2001) kirleticilerin olumsuz etkilerini ilk olarak algılayan ve doğru yansıtan canlılardır. Bu populasyonu olușturan canlıların potansiyeli ve çeșitliliği çevredeki kirlilik derecesini değerlendirmede önemli bir gösterge olarak kullanılabilmektedir (Sani ve ark., 2003; Utgikar ve ark., 2004; Ahmad ve ark., 2005). Ağır metallerin yüksek konsantrasyonları mikroorganizma populasyonu ve aktivitelerini değiștirerek toprak verimliliğini olumsuz etkilemektedir (Friedlova, 2010).

Krom (Cr) toprak kirliliğine sebep olan belli bașlı ağır metaller arasında yer almaktadır (Lenart ve Wolny- Koladka, 2013). Toprak mikroorganizmalarına karșı son derece toksik etki gösteren bir metal olup endüstride yaygın kullanımına bağlı olarak, çevresel ortamlarda ciddi bir kirletici haline gelmiștir. Krom doğada $\mathrm{Cr}$ (III) ve $\mathrm{Cr}(\mathrm{VI})$ formunda bulunmaktadır (Apte ve ark., 2006). Kromat endüstrisi, topraklar için krom kirliliği açısından tehlike olușturmaktadır (Alcântara ve ark., 2007). Bu nedenle uzun süre kroma maruz kalmıș topraklarda mikroorganizma fonksiyonlarındaki değișimin araștırılması önemli olmaktadır. Yapılan bir çalıșma, toprağa artan dozlarda (0-100 mg/ kg) uygulanan kromun, toprağın mikroorganizma ve enzim aktivitesini önemli ölçüde düșürdüğünü göstermiștir (Dotaniya ve ark., 2017).

Toprakta, ana kayada ve havada serbest ve bağlı azotun bulunuș miktarları çok yüksek olabilmesine karșın kullanılabilirliği mikroorganizma faaliyetleri sonucu mümkün olabilmektedir (Tecimen ve Sevgi, 2008). Topraktan azot alınabilirliği toprak kalitesinin önemli bir göstergesidir (Ünver, 2007). Azot mineralizasyonu, toprak organik maddesindeki kompleks azotlu bileșiklerin ayrıșma ve transformasyonları sonucu basit inorganik azot formlarına dönüșmesi olarak tanımlanmaktadır. Biyokimyasal olan bu süreç toprak organik maddesinin kalitesi, mikrobiyal biyomas, mikrobiyal etkinlik, toprak sıcaklığı ve nemi gibi faktörler ve diğer ortam koșulları tarafından kontrol edilmektedir (Ünver, 2007).

Bu çalıșmanın amacı, Aladağ (Adana) krom maden ocağına yakın ve ocaktan etkilenmemiș alanlardan (Bozluk, Kızılyüksek ve Yanıkçam) alınan cevherli ve cevhersiz topraklarda potansiyel azot mineralizasyonunu kıyaslamak ve kromun mikroorganizmalara olası etkilerini ortaya koymaktır.

\section{MATERYAL VE YÖNTEM}

Adana ili Aladağ ilçesinde bulunan krom maden ișletmesi yakınlarındaki Bozluk, Kızılyüksek ve Yanıkçam mevkileri örneklik alan olarak

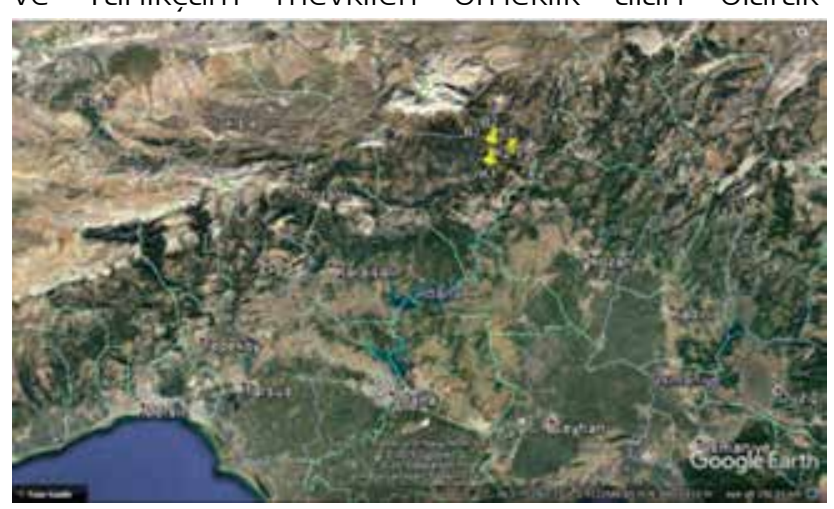

Șekil 1. Örnek alım yerlerinin uydu görüntüsü (1: Cevherli, 2: Cevhersiz)

Figure 1. Satellite view of sample locations

seçilmiștir (Șekil 1).

Her üç lokasyonda kromla kontamine olmuș ve olmamıș (cevherli ve cevhersiz) alanlardan $0-20 \mathrm{~cm}$ derinliğinden toprak örnekleri alınmıștır. Örneklik alanların koordinatları Çizelge 1' de verilmiștir.

Topraklar laboratuvarda kurutulup 2 mm' lik elekle elenerek analizlere hazır hale getirilmiștir. Toprakların bünye tipi hidrometre yöntemi ile (Bouyoucos, 1951), toprak pH'sı 1:2.5'lik topraksu karıșımında InoLab pH metresi ile (Jackson, 1958), kireç içeriği (\%) Scheibler kalsimetresi ile (Allison ve Moddie, 1965), tarla kapasitesi (TK, \%) 1/3 atmosferlik basınçlı vakum pompası ile belirlenmiștir (Demiralay, 1993). Toprakların C içeriği (\%C) Anne metodu (Duchaufour, 1970), toplam $\mathrm{N}$ içeriği (\%N) Kjeldahl metodu ve toplam 
Çizelge 1. Örneklik alanların koordinatları (X ve Y:Koordinat, Z:Denizden Yükseklik)

Table 1. Coordinates of the sampling areas (X and Y:Coordinate, Z:Altitude)

\begin{tabular}{lccc}
\hline Lokasyon & X & Y & Z \\
\hline Bozluk-Cevherli & 4171621.48 & 713339.48 & 1161.04 \\
Bozluk-Cevhersiz & 4171912.92 & 713336.87 & 1172.73 \\
Kızılyüksek-Cevherli & 4165312.89 & 715015.89 & 1218.32 \\
Kızılyüksek-Cevhersiz & 4165057,09 & 714498.87 & 1264.14 \\
Yanıkçam-Cevherli & 4170015.91 & 719005.97 & 1545.39 \\
Yanıkçam-Cevhersiz & 4169808.46 & 719351.17 & 1563.12 \\
\hline
\end{tabular}

$\mathrm{Cr}$ içerikleri ise ICP-OES ile yaș yakma yöntemine (Reisenauer, 1982) göre belirlenmiștir.

Azot mineralizasyonu için toprak örnekleri 750 ml'lik inkübasyon kavanozlarına konulup tarla kapasitelerinin \%80'i oranında nemlendirilmiștir. Hava girișini sağlamak için kavanozların ağzı ince bir bez ile kapatılıp $28^{\circ} \mathrm{C}$ de 42 gün boyunca inkübasyona bırakılmıștır. 11., 26. ve 42. günler sonunda topraklar, $200 \mathrm{ml} 1.0 \mathrm{~N}$ $\mathrm{CaCl}_{2}$ çözeltisi ile 1 saat karıștırılıp çalkalanmıș ve süzüldükten sonra süzükte Parnas-Wagner metoduna göre Mineral Azot $\left(\mathrm{NH}_{4}{ }^{+}-\mathrm{N}, \mathrm{NO}_{3}{ }^{-} \mathrm{N}\right)$ içerikleri belirlenmiștir (Lemée, 1967; Gökçeoğlu, 1979). Krom madeni alanından alınan cevherli ve cevhersiz topraklar kontrol grubu olarak direk inkübasyona bırakılmıștır. Ayrıca kontrol grubu dıșında, kromun etkisini kıyaslamak için ayrı bir grup olarak in vitro toprakların toplam $\mathrm{Cr}$ içeriğine eș değer oranda $\mathrm{Cr}$ içeren $\mathrm{K}_{2} \mathrm{Cr}_{2} \mathrm{O}_{7}$ karıștırılıp azot mineralizasyonları incelenmiștir. Dolayısıyla bu grupta, toplam $\mathrm{Cr}$ içeriğine eș değer oranda $\mathrm{Cr}$ içeren $\mathrm{K}_{2} \mathrm{Cr}_{2} \mathrm{O}_{7}$ ilavesinden sonra tüm toprakların Cr içeriği bașlangıca göre 2 kat olmuștur.

Araștırma verilerinin istatistiksel analizi SPSS 21.0 paket programı ile yapılmıștır. Tüm örneklerin analiz sonuçları 3 tekrarlı olarak ortalama \pm standart hata olarak belirlenmiș, bu sonuçların aralarındaki farklar Tukey HSD ile ortaya konmuș ve çizelge ve șekillerde sunulmuștur. Tüm istatistik analiz için önem düzeyi $P \leq 0.05$ olarak alınmıștır.

\section{BULGULAR VE TARTIȘMA}

Toprakların fiziksel ve kimyasal analiz sonuçları istatistiksel olarak değerlendirilmiș, ortalama ve standart hata değerleri Çizelge 2' de verilmiștir. Her üç lokasyonun tüm toprakları kumlu killi tınlı (SCL) olup tarla kapasiteleri 21.15 ile 28.35 (\%) arasında ve genel olarak cevhersiz topraklarda daha yüksek bulunmuștur. Tüm toprakların $\mathrm{pH}^{\prime}$ ları ise hafif alkali olup aralarında istatistiksel olarak fark gözlenmemiștir (P>0.05), (Çizelge 2).

Çizelge 2. Bozluk, Kızılyüksek ve Yanıkçam topraklarının bazı fiziksel ve kimyasal özellikleri

Table 2. Soils of Bozluk, Kızılyüksek and Yanıkçam some physical and chemical properties

\begin{tabular}{lrrrrrr}
\hline \multicolumn{7}{c}{ Bölgeler } \\
\hline Analizler & Bozluk & Kızlyüksek & Yanıkçam & Bozluk & Kızllyüksek & \multicolumn{1}{c}{ Yanıkçam } \\
\hline Kum(\%) & $61,72 \pm 0,91$ & $71,36 \pm 0,49$ & $60,54 \pm 0,33$ & $56,57 \pm 1,19$ & $62,58 \pm 0,95$ & $65,50 \pm 0,69$ \\
Silt(\%) & $18,24 \pm 0,62$ & $13,90 \pm 0,26$ & $15,09 \pm 0,89$ & $16,40 \pm 0,67$ & $13,24 \pm 0,74$ & $11,72 \pm 1,00$ \\
Kil(\%) & $20,71 \pm 0,31$ & $15,84 \pm 051$ & $23,93 \pm 0,88$ & $22,29 \pm 0,50$ & $21,96 \pm 1,23$ & $20,90 \pm 0,22$ \\
Tekstür tipi & & \multicolumn{5}{c}{ Kumlu Killi Tınlı(SCL) } \\
TK(\%) & $24,40 \pm 1,18$ & $21,15 \pm 0,92$ & $27,60 \pm 2,25$ & $28,35 \pm 2,10$ & $25,80 \pm 1,25$ & $24,50 \pm 0,88$ \\
PH & $7,38 \pm 0,01$ & $7,45 \pm 0,02$ & $7,41 \pm 0,02$ & $7,38 \pm 0,02$ & $7,39 \pm 0,03$ & $7,40 \pm 0,03$ \\
C(\%) & $2,10 \pm 0,05$ & $1,94 \pm 0,10$ & $2,63 \pm 0,09$ & $1,77 \pm 0,05$ & $1,95 \pm 0,10$ & $1,34 \pm 0,04$ \\
N(\%) & $0,18 \pm 0,00$ & $0,18 \pm 0,00$ & $0,20 \pm 0,01$ & $0,16 \pm 0,01$ & $0,18 \pm 0,01$ & $0,15 \pm 0,01$ \\
C/N & $11,89 \pm 0,05$ & $10,62 \pm 0,70$ & $12,92 \pm 0,31$ & $11,12 \pm 0,28$ & $10,83 \pm 0,10$ & $8,74 \pm 0,41$ \\
Cr(ppm) & $229,17 \pm 0,02$ & $296,10 \pm 0,01$ & $309,59 \pm 0,01$ & $205,51 \pm 0,40$ & $213,43 \pm 0,16$ & $258,07 \pm 0,24$ \\
\hline
\end{tabular}


Çizelge 3. Bozluk, Kızılyüksek ve Yanıkçam topraklarının azot mineralizasyonları (42 gün)

Table 3. Nitrogen mineralization the soils of Bozluk, Kızılyüksek and Yanıkçam (42 days)

\begin{tabular}{|c|c|c|c|c|c|c|c|c|c|}
\hline \multicolumn{4}{|c|}{$\mathrm{HN}_{4}{ }^{+}-\mathrm{N}$} & \multicolumn{5}{|c|}{$\mathrm{NO}_{3}-\mathrm{N}$} & \multirow{2}{*}{$\begin{array}{c}N \text { min } \\
(\%)\end{array}$} \\
\hline & & & 11. gün & 26. gün & 42. gün & 11.gün & 26. gün & 42. gün & \\
\hline \multirow{6}{*}{ İlavesiz } & \multirow{2}{*}{ Bozuk } & Cevhersiz & $8,44 \pm 0,23$ & $7,18 \pm 0,22$ & $6,63 \pm 0,32$ & $11,01 \pm 0,10$ & $12,06 \pm 0,14$ & $19,06 \pm 0,14$ & $1,61 \pm 0,02$ \\
\hline & & Cevherli & $7,27 \pm 0,12$ & $6,73 \pm \pm 0,16$ & $5,61 \pm 0,38$ & $10,12 \pm 0,11$ & $9,72 \pm 0,10$ & $12,99 \pm 0,20$ & $1,05 \pm 0,03$ \\
\hline & \multirow{2}{*}{ Kızılyüksek } & Cevhersiz & $9,20 \pm 0,19$ & $8,78 \pm 0,11$ & $6,00 \pm 0,15$ & $14,76 \pm 0,23$ & $20,88 \pm 0,12$ & $25,76 \pm 1,23$ & $1,73 \pm 0,07$ \\
\hline & & Cevherli & $5,02 \pm 0,05$ & $4,62 \pm 0,02$ & $4,8 \pm 0,06$ & $8,25 \pm 0,41$ & $6,47 \pm 0,25$ & $4,50 \pm 0,42$ & $0,52 \pm 0,03$ \\
\hline & \multirow{2}{*}{ Yanıkçam } & Cevhersiz & $7,14 \pm 0,20$ & $6,32 \pm 0,22$ & $5,33 \pm 0,30$ & $11,06 \pm 0,21$ & $10,82 \pm 0,42$ & $17,06 \pm 0,82$ & $1,46 \pm 0,04$ \\
\hline & & Cevherli & $6,25 \pm 0,21$ & $5,38 \pm 0,13$ & $5,92 \pm 0,24$ & $4,33 \pm 0,16$ & $3,83 \pm 0,17$ & $1,38 \pm 0,26$ & $0,36 \pm 0,00$ \\
\hline \multirow{6}{*}{$\begin{array}{c}\mathrm{K}_{2} \mathrm{Cr}_{2} \mathrm{O}_{7} \\
\text { Illaveli }\end{array}$} & \multirow{2}{*}{ Bozluk } & Cevhersiz & $9,24 \pm 0,15$ & $8,32 \pm 0,29$ & $7,44 \pm 0,31$ & $11,84 \pm 0,54$ & $14,34 \pm 0,41$ & $18,26 \pm 0,63$ & $1,61 \pm 0,04$ \\
\hline & & Cevherli & $7,36 \pm 0,18$ & $9,13 \pm 0,24$ & $9,67 \pm 0,26$ & $6,35 \pm 0,24$ & $8,12 \pm 0,32$ & $11,44 \pm 0,64$ & $1,19 \pm 0,05$ \\
\hline & \multirow{2}{*}{ Kızılyüksek } & Cevhersiz & $6,98 \pm 0,24$ & $6,22 \pm 0,41$ & $5,98 \pm 0,55$ & $10,05 \pm 0,41$ & $8,78 \pm 0,19$ & $13,38 \pm 0,59$ & $1,05 \pm 0,05$ \\
\hline & & Cevherli & $8,95 \pm 0,11$ & $6,04 \pm 0,32$ & $12,01 \pm 0,55$ & $8,52 \pm 0,34$ & $7,12 \pm 0,24$ & $3,58 \pm 0,60$ & $0,87 \pm 0,04$ \\
\hline & \multirow{2}{*}{ Yanıkçam } & ersiz & $11,21 \pm 0,25$ & $10,08 \pm 0,52$ & $15,42 \pm 0,65$ & $6,48 \pm 0,30$ & $5,66 \pm 0,18$ & $6,58 \pm 0,51$ & $1,44 \pm 0,04$ \\
\hline & & Cevherli & $5,35 \pm 0,20$ & $8,14 \pm 0,11$ & $7,08 \pm 0,12$ & $8,71 \pm 0,12$ & $6,28 \pm 0,24$ & $3,69 \pm 0,31$ & $053 \pm 0,02$ \\
\hline
\end{tabular}

Karbon içeriği en yüksek cevherli Yanıkçam $(\%$ 2.63), en düșük ise Yanıkçam cevhersiz topraklarında (\% 1.34) gözlenmiș olup aralarındaki fark anlamlıdır $(P<0.001)$. Tüm toprakların azot içerikleri ise 0.15-0.20 arasında olup cevherli topraklarda daha yüksek bulunmuștur. C/N oranları ise 8.74-12.92 arasındadır (Çizelge 2).

Toplam Cr içeriği en yüksek Yanıkçam cevherli topraklarında (309. $59 \mathrm{mg} \mathrm{kg}^{-1}$ ), en düșük ise Bozluk cevhersiz topraklarında $(205.51$ mg $\mathrm{kg}^{-1}$ ) saptanmıș olup aralarında anlamlı fark bulunmuștur ( $P<0.001$ ) (Çizelge 2$)$.

Her üç alanın krom ilave edilmeyen topraklarının ilk 11. günlük sonuçlarına göre en yüksek $\mathrm{NH}_{4}-\mathrm{N}$ (9.20 mg kg-1) ve NO3-N (14.76 mg kg-1) üretimi cevhersiz Kızılyüksek toprağında gözlenmiștir. 26. günde en yüksek amonifikasyon 18.78 mg $\mathrm{kg}^{-1}$ ), en yüksek nitrifikasyon cevhersiz Kızılyüksek (20.88 $\mathrm{mg} \mathrm{kg}^{-1}$ ) topraklarında gerçekleșmiștir. Aktif vejetasyona denk gelen 42. gün sonuçları incelendiğinde en yüksek NH4-N üretimi cevhersiz Bozluk toprağında $\left(6.63 \mathrm{mg} \mathrm{kg}^{-1}\right)$, en yüksek $\mathrm{NO}_{3}-\mathrm{N}$ üretimi ise cevhersiz Kızılyüksek $(25.76 \mathrm{mg}$ $\mathrm{kg}^{-1}$ ) toprağında meydana gelmiștir (Çizelge 3).

In vitro olarak $\mathrm{K}_{2} \mathrm{Cr}_{2} \mathrm{O}_{7}$ ilave edilen her üç Iokasyon topraklarının 11., 26. ve 42. günleri arasında en yüksek $\mathrm{NH}_{4}-\mathrm{N}$ içeriği cevhersiz Yanıkçam (sırasıyla 11.21, 10.08 ve $15.42 \mathrm{mg} \mathrm{kg}^{-1}$ ) topraklarında olup aralarında istatistiksel olarak anlamlı fark bulunmuștur $(P<0.05)$. 11., 26. ve
42. günleri arasında en yüksek nitrifikasyon ise cevhersiz Bozluk (11.84, 14.34 ve $\left.18.26 \mathrm{mg} \mathrm{kg}^{-1}\right)$ topraklarında gerçekleșmiștir (Çizelge 3).

Toprakların azot mineralizasyon oranları kıyaslandığında, hem lokasyon hem de cevherli ve cevhersiz topraklardan kaynaklanan anlamlı farklar ortaya çıkmıștır (Tablo 2). Her üç lokasyonda da $\mathrm{Cr}$ ilave edilen ve edilmeyen cevhersiz toprakların azot mineralizasyon oranları, cevherli topraklardan daha yüksek bulunmuștur. En yüksek mineralleșme oranı $\mathrm{K}_{2} \mathrm{Cr}_{2} \mathrm{O}_{7}$ ilave edilmeyen cevhersiz Kızılyüksek toprağında $1 \%$ 1.73), en düșük ise yine ilavesiz cevherli Yanıkçam (\% 0.36) toprağında gözlenmiștir.

Toprak tipi, anamateryalin kökeni, organik maddenin kalitesi (C/N oranı, lignin içeriği) ve toprağın ağır metal içeriği gibi ortam koșulları biyokimyasal bir süreç olan azot mineralizasyonunu etkilemektedir (Ünver, 2007). Krom içeriklerine göre mineralizasyon oranları değerlendirildiğinde en yüksek krom (309.59 m mg kg-1 $\mathrm{Cr}^{\prime}$ da \% 0.36) miktarına sahip toprağın azot mineralizasyonu ile en düșük oran (205.51 mg kg-1 $\mathrm{Cr}^{\prime}$ da \% 1.61 ) arasında 4.47 kat fazlalık bulunmaktadır. Krom miktarı azaldıkça azot mineralizasyon oranının arttığını söylemek mümkündür. Tüm topraklar arasında en düșük azot mineralizasyon oranı cevherli Yanıkçam toprağında saptanmıș olup, bu durum toprağın yüksek $\mathrm{Cr}$ içeriği 1309.59 $\mathrm{mg} \mathrm{kg}$ ) ile açıklanabilir. Bu lokasyondaki $\mathrm{Cr}$ konsantrasyonunun topraktaki amonyak ve nitrat 
bakterilerinin faaliyetlerini inhibe edici bir etkiye neden olduğu anlașılmaktadır. Krom ilavesinin cevhersiz topraklarda azot mineralizasyon oranlarını çok olumsuz etkilemediği, buna karșlık cevherli topraklarda arttırdığı gözlenmektedir. Aslında burada krom kaynağı olarak toprağa karıștırılan $\mathrm{K}_{2} \mathrm{Cr}_{2} \mathrm{O}_{7}^{\prime}$ nın içerdiği bol oksijenin $\mathrm{NO}_{3}$ olușumunu arttırarak azot mineralizasyon oranlarının yüksek çıkmasına neden olduğu, hatta bu topraklara adapte olmuș mikroorganizmaların krom varlığına özel bir tolerans geliștirdiği de düșünülebilir. Buna benzer olarak Walpola ve ark. (2011)' da, Cd ilave edilmiș toprakların azot mineralizasyonunu kontrol toprağına göre daha düșük bulmușlardır.

Bu çalıșma sonucuna göre Kızılyüksek ve Yanıkçam topraklarındaki mikroorganizmaların kroma daha hassas olduklarını söylemek mümkündür. Dotaniya ve ark. (2017)' da yaptıkları çalıșmada artan $\mathrm{Cr}$ dozlarının mikroorganizma ve enzim faaliyetini düșürdüğünü saptamıștır. Hem $\mathrm{K}_{2} \mathrm{Cr}_{2} \mathrm{O}_{7}$ ilaveli, hem de ilavesiz Bozluk topraklarında mineralizasyon oranları birbirine yakın bulunmuștur. Buna göre 205, 51 (BozlukCevhersiz) ve 229, 17 (Bozluk-Cevherli) mg kg' 'lik $\mathrm{Cr}$ içeriklerinin bu bölge toprağı için çok olumsuz etki yapmadığı gözlenmiștir.

Mikroorganizma ve ağır metal ilișkisini etkileyen en önemli parametreler toprak pH'sı, kilin kalitesi ve miktarı, metal iyonları ve inorganik bileșiklerdir (Nwuche ve Ugoji, 2008). Toprak pH' sı topraktaki metallerin çözünebilirliği, kullanılabilirliği ve toksisitesini büyük ölçüde etkilemektedir (Baath ve Arnebrant, 1994; Martyn ve Skwaryło-Bednarz 2005). Wang ve ark. (2007) asidik karakterli topraklarda çok düșük metal konsantrasyonlarının bile toprak mikroorganizmalarını olumsuz etkilediğini tespit etmișlerdir.

Dünya topraklarının 5-3000 $\mathrm{mg} \mathrm{kg}^{-1}$ arasında $\mathrm{Cr}$ içerdiği bilinmektedir (Allaway, 1968). Bu çalıșma topraklarının Cr içerikleri düșük bulunmuș olup bu topraklarda yașayan mikroorganizmaların özel bir mekanizma geliștirerek doğal dengeyi sağlayıp korudukları sonucuna varılabilir.

\section{SONUC̣LAR}

Araștırma sonuçlarına göre krom varlığının toprak özelliklerine bağlı olarak toprak dengesini olumsuz yönde etkilediği ve bu etkinin toprak mikroorganizmaları tarafından tolere edilebildiğini söylemek mümkündür. Bu doğrultuda azot mineralizasyonunun topraktaki ağır metal kirliliğinde bir gösterge olabileceği söylenebilir.

\section{KAYNAKLAR}

Ahmad I, Hayat S, Ahmad A, Inam A, Samiullah I (2005). Effect of heavy metal on survival of certain groups of indigenous soil microbial population. Journal of Applied Sciences and Environmental Management, 9: 115-121.

Alcântara M K, Neto V A, Camargo O A, Cantarella H (2007). Nitrogen mineralization in soils treated with tannery sludge. Pesquisa Agropecuária Brasileira, 40: 547-555

Allaway W H (1968). Agronomic control over the environmental cycling of trace elements. Advances in Agronomy, 20: 235-274.

Allison LE, Moodie CD (1965). Carbonate. In: C.A. Black et al (ed.) Methods of Soil Analysis, Part 2. Agronomy., Am. Soc. Of Agron., Inc., Madison, Wisconsin, U.S.A. 9: 1379-1400.

Apte A D, Tare V, Bose P (2006). Extent of oxidation of $\mathrm{Cr}(\mathrm{III})$ to $\mathrm{Cr}(\mathrm{VI})$ under various conditions pertaining to natural environment. Journal of Hazardous Materials, 164-174.

Bààth E, Arnebrant K (1994). Growth-rate and response of bacterial communities to $\mathrm{pH}$ in limed and ash treated forest soils. Soil Biology and Biochemistry, 26: 995-1001.

Bouyoucos G S (1951). A recalibration of the hydrometer for mohing mechanical analysis of soil. Agronomy Journal, 43: 434-438.

Chaudhary A M, MacGrath S P, Knight B P, Johnson D $L$, Jones K C (1996). Toxicity of organic compounds to the indigenous population of R. leguminosorum bv. trifolii in soil. Soil Biology and Biochemistry, 28: 1483-1487.

Demiralay i (1993). Toprak Fiziksel Analizleri. Atatürk Üniversitesi Ziraat Fakültesi Yayınları No: 143, sf: 78-89, Erzurum.

Dotaniya M L, Rajendiran S, Meena $V$ D, Saha J K, Vassanda Coumar M, Kundu S, Patra A K (2017). Influence of chromium contamination on carbon mineralization and enzymatic activities in vertisol. Agricultural Research, 6: 91-96.

Duchaufour P (1970). Precis de Pedologie. Masson et Cle, Editeurs, p: 435-437, Paris.

Friedlova M (2010). The influence of heavy metals on soil biological and chemical properties. Soil and Water Research, 5(1):21-27

Gökçeoğlu M (1979). Bazı bitki organlarındaki azot, fosfor ve potasyumun bir vejetasyon periyodundaki değișimi. Doğa Tarım ve Ormancilık, 3: 192-199.

Jackson M L (1958). Soil Chemical Analysis. Pretice-Hall, Inc. Englewood Cliffs, p: 1-498, New Jersey, U.S.A.

Kebir T, Bouhadjera K (2011). Effects of heavy metals pollution in soil and plant in the industrial area, West Algeria. Journal of the Korean Chemical Society, 55 (6): 1018-1023.

Lemee G (1967). Investigations sur la mineralisation de I'azote et son evolution annuelle dans des humus forestiers in situ. Ecologie Plant, 2: 285-324.

Lenart A, Wolny-Koładka K (2013). The effect of heavy 
metal concentration and soil $\mathrm{pH}$ on the abundance of selected microbial groups within arcelorMittal poland steelworks in Cracow. Bulletin of Environmental Contamination and Toxicology, 90(1): 85-90.

Martyn W, Skwaryło-Bednarz B (2005). Biological properties of light soils in the area of Roztocze National Park. Acta Agrophysica, 5: 695-704.

Nwuche C O, Ugoji E O (2008). Effects of heavy metal pollution on the soil microbial activity. International Journal of Environmental Science and Technology, 5: 409-414.

Obbard J P (2001). Ecotoxicological assessment of heavy metals in sewage sludge amended soils. Applied Geochemistry, 16: 1405-1411.

Reisenauer H M (1982). Chromium, in A. L. Page et al. (eds), Methods of Soil Analysis, Part 2, Chemical and Microbiological Properties, 2nd ed., Agron. Monogr. Vol. 9, ASA and SSSA, Madison, WI, U.S.A., 337-346.

Sani R K, Peyton B M, Jadhyala M (2003). Toxicity of lead in aqueous medium to Desulfovibrio desulfuricans G20. Environmental Toxicology, 22 (2): 252-260.
Tecimen H B, Sevgi O (2008). Orman topraklarında mikroorganizmalar tarafından gerçekleștirilen azot dönüșümleri. SDÜ Orman Fakültesi Dergisi, cilt.A: 179-189.

Utgikar V P, Chaudhary N, Koeniger A, Tabak H H, Haines J R, Govind R (2004). Toxicity of metals and metal mixtures: Analysis of concentration and time dependence for zinc and copper. Water Research, 38 (17): 3651- 3658.

Ünver M C (2007). Murat dağı (Ușak, Kütahya) alpin ve subalpin bölgesinin bazı bitki topluluklarında azot dönüșümleri üzerinde araștırmalar. Uludağ Üniversitesi, Doktora Tezi, $116 \mathrm{~s}$.

Walpola B C, Arunakumara K K I U, Yoon M H (2011). Evaluation of nitrogen mineralization in soil polluted by zinc and cadmium. Korean Journal of Soil Science and Fertilizer, 44(4): 559-564.

Wang J, Lu Y, Shen G (2007). Combined effects of cadmium and butachlor on soil enzyme activities and microbial community structure. Environmental Geology, 51: 1221-1228. 
toprajks u.

58| 
toprâjs u. 
toprajks u.

$60 \mid$ 
toprâjs u. 
toprajks u.

$62 \mid$ 
toprâjs u. 
toprajks u.

$64 \mid$ 